\title{
MODEL OSÍDLENIA SEVEROVÝCHODNÉHO SLOVENSKA V POVODÍ SEKČOVA NA PODKLADE DÁT ZÍSKANÝCH Z PROSTREDIA GIS
}

\author{
Paleolit, neolit, eneolit ${ }^{1}$
}

\author{
RÓB ERT M A LČEK - E VA HORVÁTHOVÁ - L UCIA L U ŠTíK O VÁ
}

\begin{abstract}
A Model of Settlement of Northeastern Slovakia in the Sekčov Drainage Basin Based on Data Obtained from GIS Environment. Paleolithic, Neolithic, Eneolithic. The study is focused on assessment of the settlement in the region of Šariš in the drainage basin of the Sekčov and its contributaries. It contains a database and map materials with indicated archaeological sites from the periods of the Paleolithic, Neolithic, Eneolithic, Bronze Age, Hallstatt, La Tène and Roman periods. With regard to the amount and complexity of the information excerpted from analyses in the GIS environment, we have decided to publish the results of our research in two stages, in the chronological succession of subsequent periods. In the first stage, we synthesize - by means of the submitted publication - results of the research from the early prehistoric periods (Paleolithic, Neolithic, Eneolithic). We analyze natural properties of the settled sites in association with the potential water streams and the distance from them, the route of the main communication corridor, the character of slopes and altitude of the terrain, the composition and fertility value of pedo-ecological units (BPEJ/FVPEU), their typology-production categories (TPK/TPC), as well as with other indicators, with their possible tracing in the modern landscape. The suggested settlement zones and their characteristics are finally confronted with previously published information on the settlement near the upper and middle Torysa river.
\end{abstract}

Keywords: Eastern Slovakia, Paleolithic, Neotlithic, Eneolithic, GIS, environment, settlement structure.

\section{ÚVOD}

Štúdia je zameraná na aktualizáciu údajov o výskyte a čo najpresnejšom lokalizovaní archeologických nálezísk v okolí povodia Sekčova a jeho prítokov, ktoré odvodňujú čast̉ územia severovýchodného Slovenska (obr. 1). Analyzuje a vyhodnocuje zhody a rozdiely $\mathrm{v}$ dynamike osídlenia centrálnej časti šarišského regiónu $\mathrm{v}$ ranných prehistorických dobách. ${ }^{2} Z$ hydrogeografie sledovaného územia sa do úvahy bral celý tok Sekčova od jeho prameňa, ktorý vyviera vo východnej časti pohoria Čergov (v k. ú. obce Hertník), až po vyústenie rieky do Torysy v centrálnej časti intravilánu mesta Prešov (tabela 1). Monitorované povodie Sekčova preteká piatimi geomorfologickými celkami (Čergovom, Ondavskou vrchovinou, Beskydským predhorím, Spišsko-šarišským medzihorím, Košickou kotlinou) a pri svojej dížke $44,3 \mathrm{~km}$ odvodňuje plochu s rozlohou 35714 ha. V tejto geografickej oblasti dokážeme identifikovat 69 archeologických lokalít, ktoré sú evidované v 26 katastrálnych územiach (obr. 2-5). Z nich 18 katastrov je administratívne zaradených do okresu Prešov (kde na ploche 20824 ha evidujeme 62 lokalít) a d’alších šest’ spadá

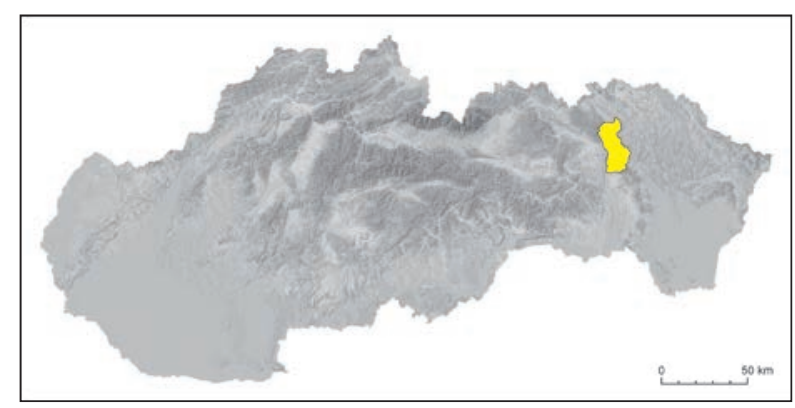

Obr. 1. Mapa Slovenska s vyznačením sledovaného územia v povodí Sekčova.

\footnotetext{
1 Príspevok vznikol s podporou grantového projektu 2/0084/18 „Vývoj a premeny sídliskových štruktúr horného Potisia v praveku a v rannej dobe dejinnej“ agentúry VEGA a projektu APVV 18-0276 „Prostredie a sídliskové siete mladšieho praveku na príklade vybratých období a regiónov Slovenska."

2 Zameriava sa len na obdobie paleolitu, neolitu a eneolitu. Je len prvou častou práce, ktorá zahrnie aj dobu bronzovú, staršiu dobu železnú a dobu rímsku. V tabelách 1 a 2 preto uvádzame všetky zozbierané lokality a aj číslovanie komponentov paleolitickej až eneolitickej sekvencie v d’alšom texte rešpektuje ich zaradenie v týchto tabelách. Podobne mapy osídlenia regiónu na obr. 2-5 zobrazujú aj lokality doby bronzovej, halštatskej, laténskej a rímskej.
} 
Tabela 1. Zoznam prítokov Sekčova a sledovanie ich trás vo vztahu ku geomorfologickým celkom a archeologickým lokalitám.

\begin{tabular}{|c|c|c|c|c|c|c|}
\hline IČ & Názov prítoku Sekčova & $\begin{array}{c}\text { Definovanie } \\
\text { prítoku Sekčova }\end{array}$ & Lokalizovanie prameňa & Tečie cez & Kataster & IČ lokality \\
\hline \multirow{2}{*}{1} & \multirow{2}{*}{ bezmenný potok } & \multirow{2}{*}{$\begin{array}{l}\text { Pravostranný } \\
\text { prítok }\end{array}$} & \multirow{2}{*}{$\begin{array}{l}\text { Ondavská vrchovina/ } \\
\text { Raslavická brázda }\end{array}$} & \multirow{2}{*}{$\begin{array}{l}\text { Ondavská vrchovina/ } \\
\text { Raslavická brázda }\end{array}$} & Herník & - \\
\hline & & & & & Bartošovce & - \\
\hline \multirow{2}{*}{2} & \multirow{2}{*}{ Pastovník } & \multirow{2}{*}{$\begin{array}{l}\text { Pravostranný } \\
\text { prítok }\end{array}$} & \multirow{2}{*}{ Čergov } & \multirow{2}{*}{$\begin{array}{l}\text { Ondavská vrchovina/ } \\
\text { Raslavická brázda }\end{array}$} & Hertník & - \\
\hline & & & & & Bartošovce & 1 \\
\hline \multirow{3}{*}{3} & \multirow{3}{*}{$\begin{array}{l}\text { Hlboký potok } \\
\text { (pravostranný prítok - Krivý } \\
\text { potok) }\end{array}$} & \multirow{3}{*}{$\begin{array}{l}\text { Pravostranný } \\
\text { prítok }\end{array}$} & \multirow{3}{*}{ Čergov } & \multirow{3}{*}{$\begin{array}{l}\text { Ondavská vrchovina/ } \\
\text { Raslavická brázda }\end{array}$} & Bartošovce & - \\
\hline & & & & & Fričkovce & - \\
\hline & & & & & Hertník & - \\
\hline \multirow{3}{*}{4} & \multirow{3}{*}{$\begin{array}{l}\text { Fričkovský potok } \\
\text { (pravostranný prítok - } \\
\text { Osikovský potok) }\end{array}$} & \multirow{3}{*}{$\begin{array}{l}\text { Pravostranný } \\
\text { prítok }\end{array}$} & \multirow{3}{*}{ Čergov } & \multirow{3}{*}{$\begin{array}{l}\text { Ondavská vrchovina/ } \\
\text { Raslavická brázda }\end{array}$} & Fričkovce & - \\
\hline & & & & & Osikov & - \\
\hline & & & & & Vaniškovce & - \\
\hline \multirow{3}{*}{5} & \multirow{3}{*}{$\begin{array}{l}\text { Dial'ne } \\
\text { (pravostranný prítok - Potôčik) }\end{array}$} & \multirow{3}{*}{$\begin{array}{l}\text { Pravostranný } \\
\text { prítok }\end{array}$} & \multirow{3}{*}{ Čergov } & \multirow{3}{*}{$\begin{array}{l}\text { Ondavská vrchovina/ } \\
\text { Raslavická brázda }\end{array}$} & Osikov & - \\
\hline & & & & & Vaniškovce & - \\
\hline & & & & & Závadka & - \\
\hline 6 & bezmenný potok & $\begin{array}{l}\text { Pravostranný } \\
\text { prítok }\end{array}$ & $\begin{array}{l}\text { Ondavská vrchovina/ } \\
\text { Raslavická brázda }\end{array}$ & $\begin{array}{l}\text { Ondavská vrchovina/ } \\
\text { Raslavická brázda }\end{array}$ & Vaniškovce & - \\
\hline 7 & bezmenný potok & $\begin{array}{l}\text { Pravostranný } \\
\text { prítok }\end{array}$ & $\begin{array}{l}\text { Ondavská vrchovina/ } \\
\text { Raslavická brázda }\end{array}$ & $\begin{array}{l}\text { Ondavská vrchovina/ } \\
\text { Raslavická brázda }\end{array}$ & Vyšné Raslavice & - \\
\hline \multirow{4}{*}{8} & & & & & Geraltov & - \\
\hline & Laz & Pravostranný & & Ondavská vrchovina/ & Osikov & - \\
\hline & Podubinský jarok) & prítok & Giluavska vichiovita & Raslavická brázda & Žatkovce & - \\
\hline & & & & & Vyšné Raslavice & - \\
\hline & & & & & Žatkovce & - \\
\hline 9 & Podhorckínetok & Pravostranný & Ondaycká vrchovina & Ondavská vrchovina/ & Vel'ký Slivník & - \\
\hline 9 & rodnorsky potok & prítok & Undavska vicnovina & Raslavická brázda & Vyšné Raslavice & - \\
\hline & & & & & Demjata & - \\
\hline 10 & bezmenný potok & $\begin{array}{l}\text { Pravostranný } \\
\text { prítok }\end{array}$ & Ondavská vrchovina & $\begin{array}{l}\text { Ondavská vrchovina/ } \\
\text { Raslavická brázda }\end{array}$ & Demjata & - \\
\hline & & & & & Vel'ký Slivník & - \\
\hline 11 & potok Zápotok & $\begin{array}{l}\text { Pravostranný } \\
\text { prítok }\end{array}$ & Ondavská vrchovina & $\begin{array}{l}\text { Beskydské predhorie/ } \\
\text { Záhradnianska brázda }\end{array}$ & Demjata & - \\
\hline & & & & & Tulčík & 62 \\
\hline & & & & & Hradisko & - \\
\hline & & & & & Mošurov & - \\
\hline & & & & & Babin potok & - \\
\hline & Ternianka & & & & Terňa & 56,57 \\
\hline 12 & $\begin{array}{l}\text { (l'avostranné prítoky - Mošuro- } \\
\text { vanka, Závadčiansky potok) }\end{array}$ & Pravostranný & Čergov & $\begin{array}{l}\text { Ondavská vrchovina } \\
\text { Beskydské predhorie/ }\end{array}$ & Záhradné & $67,68,69$ \\
\hline & $\begin{array}{l}\text { (pravostranné prítoky - Zádlhé, } \\
\text { Potocký potok, Maliniak) }\end{array}$ & prítok & & Záhradnianska brázda & Tulčík & $61,63,64$ \\
\hline & & & & & Závadka & - \\
\hline & & & & & Geraltov & - \\
\hline & & & & & Malý Slivník & - \\
\hline & & & & & Vel'ký Slivník & - \\
\hline 13 & bezmenný potok & $\begin{array}{l}\text { Pravostranný } \\
\text { prítok }\end{array}$ & $\begin{array}{l}\text { Spišsko-šarišské } \\
\text { medzihorie/Stráže }\end{array}$ & $\begin{array}{l}\text { Ondavská vrchovina } \\
\text { Beskydské predhorie/ } \\
\text { Záhradnianska brázda }\end{array}$ & Fulianka & $10,14,15$ \\
\hline 14 & Fintický potok & $\begin{array}{l}\text { Pravostranný } \\
\text { prítok }\end{array}$ & $\begin{array}{l}\text { Spišsko-šarišské } \\
\text { medzihorie/Stráže }\end{array}$ & $\begin{array}{l}\text { Košická kotlina/ } \\
\text { Toryská pahorkatina }\end{array}$ & Fintice & $\begin{array}{l}3,4,5,6 \\
7,8,9\end{array}$ \\
\hline
\end{tabular}


Tabela 1. Pokračovanie.

\begin{tabular}{|c|c|c|c|c|c|c|}
\hline IČ & Názov prítoku Sekčova & $\begin{array}{c}\text { Definovanie } \\
\text { prítoku Sekčova }\end{array}$ & Lokalizovanie prameňa & Tečie cez & Kataster & IČ lokality \\
\hline \multirow{3}{*}{15} & \multirow{3}{*}{ Cigší/Segší/Tichší potok } & \multirow{3}{*}{$\begin{array}{l}\text { L'avostranný } \\
\text { prítok }\end{array}$} & \multirow{3}{*}{ Čergov } & \multirow{3}{*}{$\begin{array}{l}\text { Ondavská vrchovina/ } \\
\text { Raslavická brázda }\end{array}$} & Šiba & - \\
\hline & & & & & Hertník & - \\
\hline & & & & & Bartošovce & - \\
\hline 16 & bezmenný potok & $\begin{array}{l}\text { L'avostranný } \\
\text { prítok }\end{array}$ & $\begin{array}{l}\text { Ondavská vrchovina/ } \\
\text { Raslavická brázda }\end{array}$ & $\begin{array}{l}\text { Ondavská vrchovina/ } \\
\text { Raslavická brázda }\end{array}$ & Bartošovce & - \\
\hline 17 & bezmenný potok & $\begin{array}{l}\text { L'avostranný } \\
\text { prítok }\end{array}$ & $\begin{array}{l}\text { Ondavská vrchovina/ } \\
\text { Raslavická brázda }\end{array}$ & $\begin{array}{l}\text { Ondavská vrchovina/ } \\
\text { Raslavická brázda }\end{array}$ & Bartošovce & - \\
\hline \multirow{9}{*}{18} & \multirow{9}{*}{$\begin{array}{l}\text { Rešovka/Hrabovec } \\
\text { (pravostranný prítok - Hrabovec) } \\
\text { (lavostranný prítok - Rešovka) } \\
\text { (pravostranný prítok - Brôdok) }\end{array}$} & \multirow{9}{*}{$\begin{array}{l}\text { L'avostranný } \\
\text { prítok }\end{array}$} & \multirow{9}{*}{ Ondavská vrchovina } & \multirow{9}{*}{$\begin{array}{l}\text { Ondavská vrchovina/ } \\
\text { Raslavická brázda }\end{array}$} & Rešov & - \\
\hline & & & & & Kl'ušov & 29 \\
\hline & & & & & Kobyly & 30 \\
\hline & & & & & Nižná Vol’a & - \\
\hline & & & & & Ol'šavce & - \\
\hline & & & & & Janovce & - \\
\hline & & & & & Tročany & $36,59,60$ \\
\hline & & & & & Vaniškovce & - \\
\hline & & & & & Raslavice & 54 \\
\hline \multirow{2}{*}{19} & \multirow{2}{*}{$\begin{array}{l}\text { Suchý/Bogliarsky potok } \\
\text { (pravostranný prítok - } \\
\text { Suchý potok) }\end{array}$} & \multirow{2}{*}{$\begin{array}{l}\text { L'avostranný } \\
\text { prítok }\end{array}$} & \multirow{2}{*}{$\begin{array}{l}\text { Ondavská vrchovina/ } \\
\text { Raslavická brázda }\end{array}$} & \multirow{2}{*}{$\begin{array}{l}\text { Ondavská vrchovina/ } \\
\text { Raslavická brázda }\end{array}$} & Raslavice & - \\
\hline & & & & & Lopúchov & - \\
\hline \multirow{2}{*}{20} & \multirow{2}{*}{ bezmenný potok } & \multirow{2}{*}{$\begin{array}{l}\text { L'avostranný } \\
\text { prítok }\end{array}$} & \multirow{2}{*}{$\begin{array}{l}\text { Ondavská vrchovina/ } \\
\text { Raslavická brázda }\end{array}$} & \multirow{2}{*}{$\begin{array}{l}\text { Ondavská vrchovina/ } \\
\text { Raslavická brázda }\end{array}$} & Raslavice & - \\
\hline & & & & & Demjata & - \\
\hline 21 & bezmenný potok & $\begin{array}{l}\text { L'avostranný } \\
\text { prítok }\end{array}$ & $\begin{array}{l}\text { Ondavská vrchovina/ } \\
\text { Raslavická brázda }\end{array}$ & $\begin{array}{l}\text { Ondavská vrchovina/ } \\
\text { Raslavická brázda }\end{array}$ & Demjata & 2 \\
\hline 22 & bezmenný potok & $\begin{array}{l}\text { L'avostranný } \\
\text { prítok }\end{array}$ & $\begin{array}{l}\text { Beskydské predhorie/ } \\
\text { Záhradnianska brázda }\end{array}$ & $\begin{array}{l}\text { Beskydské predhorie/ } \\
\text { Záhradnianska brázda }\end{array}$ & Demjata & - \\
\hline \multirow{2}{*}{23} & \multirow{2}{*}{ bezmenný potok } & \multirow{2}{*}{$\begin{array}{l}\text { L'avostranný } \\
\text { prítok }\end{array}$} & \multirow{2}{*}{$\begin{array}{l}\text { Beskydské predhorie/ } \\
\text { Záhradnianska brázda }\end{array}$} & \multirow{2}{*}{$\begin{array}{l}\text { Beskydské predhorie/ } \\
\text { Záhradnianska brázda }\end{array}$} & Demjata & - \\
\hline & & & & & Tulčík & - \\
\hline 24 & Čakaň & $\begin{array}{l}\text { L'avostranný } \\
\text { prítok }\end{array}$ & $\begin{array}{l}\text { Beskydské predhorie/ } \\
\text { Záhradnianska brázda }\end{array}$ & $\begin{array}{l}\text { Beskydské predhorie/ } \\
\text { Záhradnianska brázda }\end{array}$ & Tulčík & - \\
\hline 25 & Dubinský potok & $\begin{array}{l}\text { L'avostranný } \\
\text { prítok }\end{array}$ & $\begin{array}{l}\text { Beskydské predhorie/ } \\
\text { Záhradnianska brázda }\end{array}$ & $\begin{array}{l}\text { Beskydské predhorie/ } \\
\text { Záhradnianska brázda }\end{array}$ & Tulčík & - \\
\hline \multirow{3}{*}{26} & & & & & Tulčík & - \\
\hline & bezmenný potok & $\begin{array}{l}\text { L'avostranný } \\
\text { prítok }\end{array}$ & $\begin{array}{l}\text { Beskydské predhorie/ } \\
\text { Záhradnianska brázda }\end{array}$ & $\begin{array}{l}\text { Beskydské predhorie/ } \\
\text { Záhradnianska brázda }\end{array}$ & Fulianka & - \\
\hline & & & & & Podhorany & 41 \\
\hline 27 & Dodhoranolín not & L'avostranný & Beskydské predhorie/ & Beskydské predhorie/ & Podhorany & - \\
\hline $2 t$ & 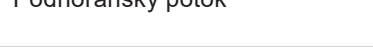 & prítok & Záhradnianska brázda & Záhradnianska brázda & Fulianka & $11,12,13$ \\
\hline & & & & & Proč & - \\
\hline & & & & & Pušovce & - \\
\hline & & & & & Čelovce & - \\
\hline & & & & & Lipníky & - \\
\hline & $\begin{array}{l}\text { Ladzinka/Ladianka } \\
\text { (l'avostranné prítoky - }\end{array}$ & & & & Nemcovce & 35 \\
\hline 28 & $\begin{array}{l}\text { Porúbsky potok, } \\
\text { Trnkovský potok, }\end{array}$ & L'avostranný & Ondavská vrchovina & Beskydské predhorie/ & Šarišská Poruba & - \\
\hline & Kapušiansky potok) & & & Záhradnianska brázda & Lada & 31,32 \\
\hline & Trstianka, Dlhý potok) & & & & Kapušany & $\begin{array}{l}19,20,21, \\
22,23,24, \\
25,26,27, \\
28\end{array}$ \\
\hline & & & & & Vyšná Šebastová & 65,66 \\
\hline & & & & & Chmel'ov & 16,17 \\
\hline
\end{tabular}


Tabela 1. Pokračovanie.

\begin{tabular}{|c|c|c|c|c|c|c|}
\hline IČ & Názov prítoku Sekčova & $\begin{array}{c}\text { Definovanie } \\
\text { prítoku Sekčova }\end{array}$ & Lokalizovanie prameňa & Tečie cez & Kataster & IČ lokality \\
\hline \multirow{6}{*}{28} & \multirow{6}{*}{$\begin{array}{l}\text { Ladzinka/Ladianka } \\
\text { (l'avostranné prítoky - } \\
\text { Porúbsky potok, } \\
\text { Trnkovský potok, } \\
\text { Kapušiansky potok) } \\
\text { (pravostranné prítoky - } \\
\text { Trstianka, Dlhý potok) }\end{array}$} & \multirow{6}{*}{ L'avostranný } & \multirow{6}{*}{ Ondavská vrchovina } & \multirow{6}{*}{$\begin{array}{l}\text { Beskydské predhorie/ } \\
\text { Záhradnianska brázda }\end{array}$} & Okružná & - \\
\hline & & & & & Trnkov & 58 \\
\hline & & & & & Šarišská Trstená & - \\
\hline & & & & & Chmel'ovec & 18 \\
\hline & & & & & Lopúchov & - \\
\hline & & & & & Podhorany & $\begin{array}{l}37,38,39 \\
40\end{array}$ \\
\hline \multirow{6}{*}{29} & \multirow{6}{*}{$\begin{array}{l}\text { Šebastovka } \\
\text { (l'avostranný prítok - } \\
\text { Šebastovík) }\end{array}$} & \multirow{6}{*}{$\begin{array}{l}\text { L'avostranný } \\
\text { prítok }\end{array}$} & \multirow{6}{*}{$\begin{array}{l}\text { Slanské vrchy/ } \\
\text { Šimonka/ } \\
\text { Zlatobanská kotlina }\end{array}$} & \multirow{6}{*}{$\begin{array}{l}\text { Košická kotlina/ } \\
\text { Toryská pahorkatina }\end{array}$} & Okružná & - \\
\hline & & & & & Podhradík & 42 \\
\hline & & & & & Vyšná Šebastová & - \\
\hline & & & & & Nižná Šebastová & - \\
\hline & & & & & Prešov & - \\
\hline & & & & & Ruská Nová Ves & - \\
\hline 30 & L'ubotický potok & $\begin{array}{l}\text { L'avostranný } \\
\text { prítok }\end{array}$ & $\begin{array}{l}\text { Košická kotlina/ } \\
\text { Toryská pahorkatina }\end{array}$ & $\begin{array}{l}\text { Košická kotlina/ } \\
\text { Toryská pahorkatina }\end{array}$ & L'ubotice & 33,34 \\
\hline 31 & Ortášsky potok & $\begin{array}{l}\text { L'avostranný } \\
\text { prítok }\end{array}$ & $\begin{array}{l}\text { Košická kotlina/ } \\
\text { Toryská pahorkatina }\end{array}$ & $\begin{array}{l}\text { Košická kotlina/ } \\
\text { Toryská pahorkatina }\end{array}$ & L'ubotice & 33,34 \\
\hline \multirow{3}{*}{32} & \multirow{3}{*}{ Šalgovský/Šalgovický potok } & \multirow{3}{*}{$\begin{array}{l}\text { L'avostranný } \\
\text { prítok }\end{array}$} & \multirow{3}{*}{$\begin{array}{l}\text { Košická kotlina/ } \\
\text { Toryská pahorkatina }\end{array}$} & \multirow{3}{*}{$\begin{array}{l}\text { Košická kotlina/ } \\
\text { Toryská pahorkatina }\end{array}$} & Teriakovce & - \\
\hline & & & & & $\begin{array}{l}\text { Prešov, } \\
\text { čast' Šalgovík }\end{array}$ & $51,52,53$ \\
\hline & & & & & Prešov & - \\
\hline \multirow[b]{2}{*}{33} & \multirow{2}{*}{$\begin{array}{l}\text { Vieska/Sol'ný potok } \\
\text { (pravostranné prítoky - Hradový } \\
\text { potok, Činaloš, Baracký potok) }\end{array}$} & \multirow{2}{*}{$\begin{array}{l}\text { L'avostranný } \\
\text { prítok }\end{array}$} & \multirow{2}{*}{$\begin{array}{l}\text { Slanské vrchy/ } \\
\text { Šimonka/ } \\
\text { Zlatobanská kotlina }\end{array}$} & \multirow{2}{*}{$\begin{array}{l}\text { Košická kotlina/ } \\
\text { Toryská pahorkatina }\end{array}$} & Ruská Nová Ves & 55 \\
\hline & & & & & $\begin{array}{l}\text { Prešov, } \\
\text { čast' Solivar }\end{array}$ & $\begin{array}{l}45,46,47 \\
48,49,50\end{array}$ \\
\hline \multirow[b]{2}{*}{34} & \multirow[b]{2}{*}{ Solivarský kanál } & \multirow{2}{*}{$\begin{array}{l}\text { L'avostranný } \\
\text { prítok }\end{array}$} & \multirow{2}{*}{$\begin{array}{l}\text { Košická kotlina/ } \\
\text { Toryská pahorkatina }\end{array}$} & \multirow{2}{*}{$\begin{array}{l}\text { Košická kotlina/ } \\
\text { Toryská pahorkatina }\end{array}$} & Dulova Ves & - \\
\hline & & & & & $\begin{array}{l}\text { Prešov, } \\
\text { čast' Solivar }\end{array}$ & 43 \\
\hline
\end{tabular}

do okresu Bardejov (kde na ploche 6366 ha registrujeme sedem lokalít; tabela 2). Do výskumu boli zahrnuté náleziská z obdobia paleolitu (bez kultúrnej identifikácie), neolitu (obývané obyvatel'stvom kultúry s východnou lineárnou keramikou skupiny Tiszadob a bukovohorskej kultúry), eneolitu (reprezentované skupinou Lažňany, badenskou kultúrou, kultúrou Nyírszég-Zatín a skupinou východoslovenských mohýl kultúry so šnúrovou keramikou), doby bronzovej (gávskej kultúry), doby halštatskej, laténskej a mladšej doby rímskej.

Z vytvorenej databázy vyplynulo, že až $68 \%$ archeologických lokalít evidujeme na základe povrchových prieskumov. ${ }^{3}$ Ďalších $25 \%$ tvoria lokality, ktorých výskum bol viazaný na záchranné akcie vyvolané rozmanitou stavebnou činnostou ${ }^{4}$ a len $6 \%$ záznamov sa viaže $\mathrm{k}$ výskumom, ktoré sú určené na vedecké účely. ${ }^{5} \mathrm{~V}$ jednom prípade je lokalita odvodená od miesta ojedinelého nálezu, čo z uvedeného celku tvorí $1 \% .^{6}$ Príspevok je $\mathrm{v}$ poradí druhým tematicky zameraným výstupom z výskumu územia severovýchodného Slovenska, v ktorom analyzujeme mieru vplyvu krajiny v úvodí Torysy za využitia priestorových dát analyzovaných v prostredí GIS (Malček a $i$. 2018, 21-52).

${ }^{3}$ Lokality 2, 3, 4, 11, 12, 13, 14, 15, 16, 17, 19, 20, 23, 24, 25, 27, 28, 29, 30, 32, 33, 34, 35, 36, 37, 38, 39, 40, 41, 43, 45, 46, 47, 48, 51, 54, $55,56,58,59,60,61,62,63,64,66,68$, spolu 47 lokalít.

4 Lokality 1, 5, 6, 7, 9, 10, 18, 21, 26, 42, 44, 49, 50, 52, 53, 65, 69, spolu 17 lokalít.

5 Lokality 8, 22, 31, 57b, spolu štyri lokality.

6 Lokalita 67. 


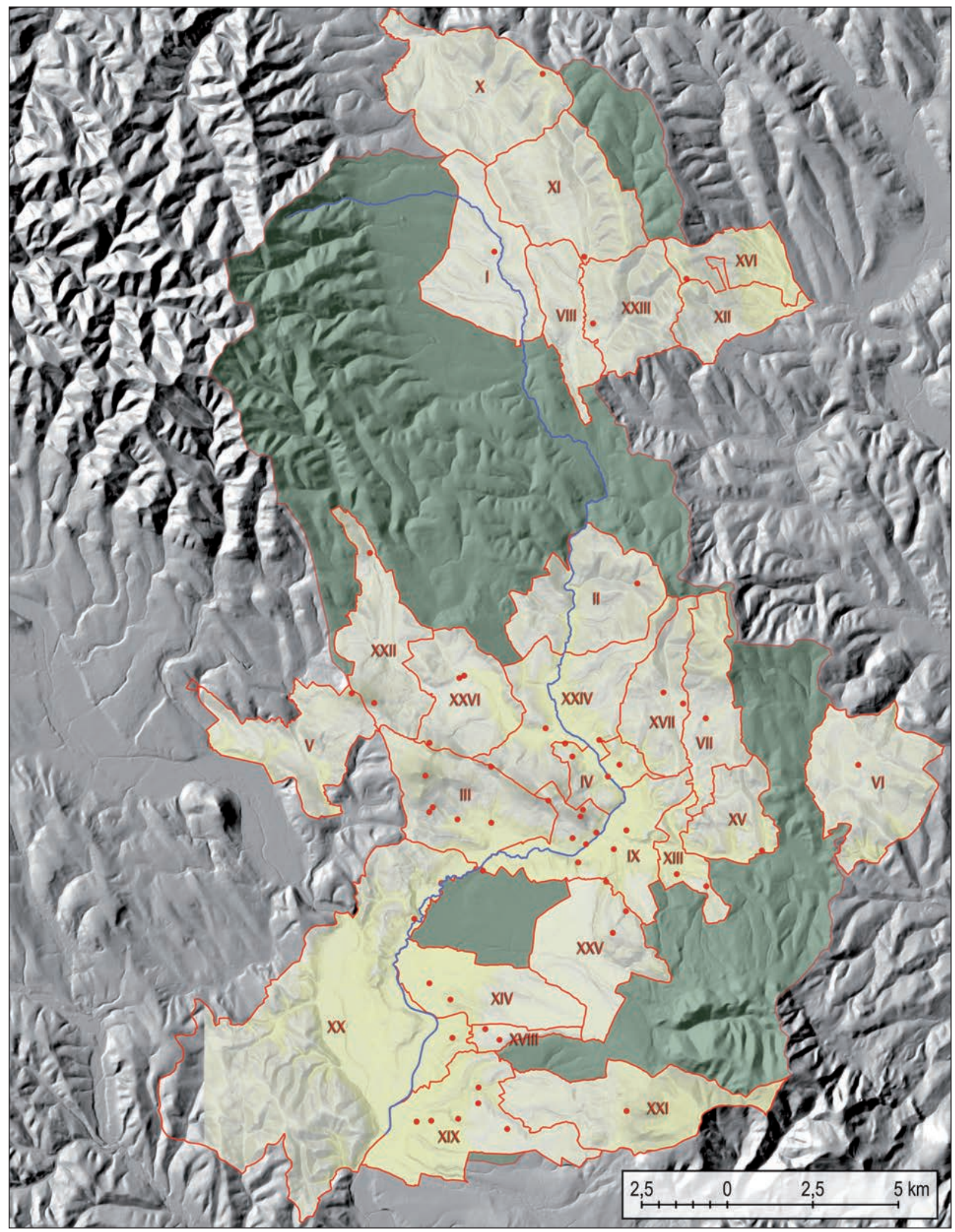

Obr. 2. Mapa sledovaného územia v povodí Sekčova. Farebne a rímskymi číslicami sú označené katastre obcí s evidovanými archeologickými lokalitami. I - Bartošovce; II - Demjata; III - Fintice; IV - Fulianka; V - Gregorovce; VI - Chmel’ov; VII - Chmel'ovec; VIII - Janovce; IX - Kapušany; X - Klušov; XI - Kobyly; XII - Kochanovce; XIII - Lada; XIV - L'ubotice; XV - Nemcovce; XVI - Ol'šavce; XVII - Podhorany; XVIII - Prešov-Šalgovík; XIX - Prešov-Solivar; XX - Prešov; XXI - Ruská Nová Ves; XXII - Terňa; XXIII - Tročany; XXIV - Tulčík; XXV - Vyšná Šebastová; XXVI - Záhradné. Červené body - archeologické lokality; olivovo zelená plocha - povodie Sekčova (mapový podklad ŠÚGDŠ). 


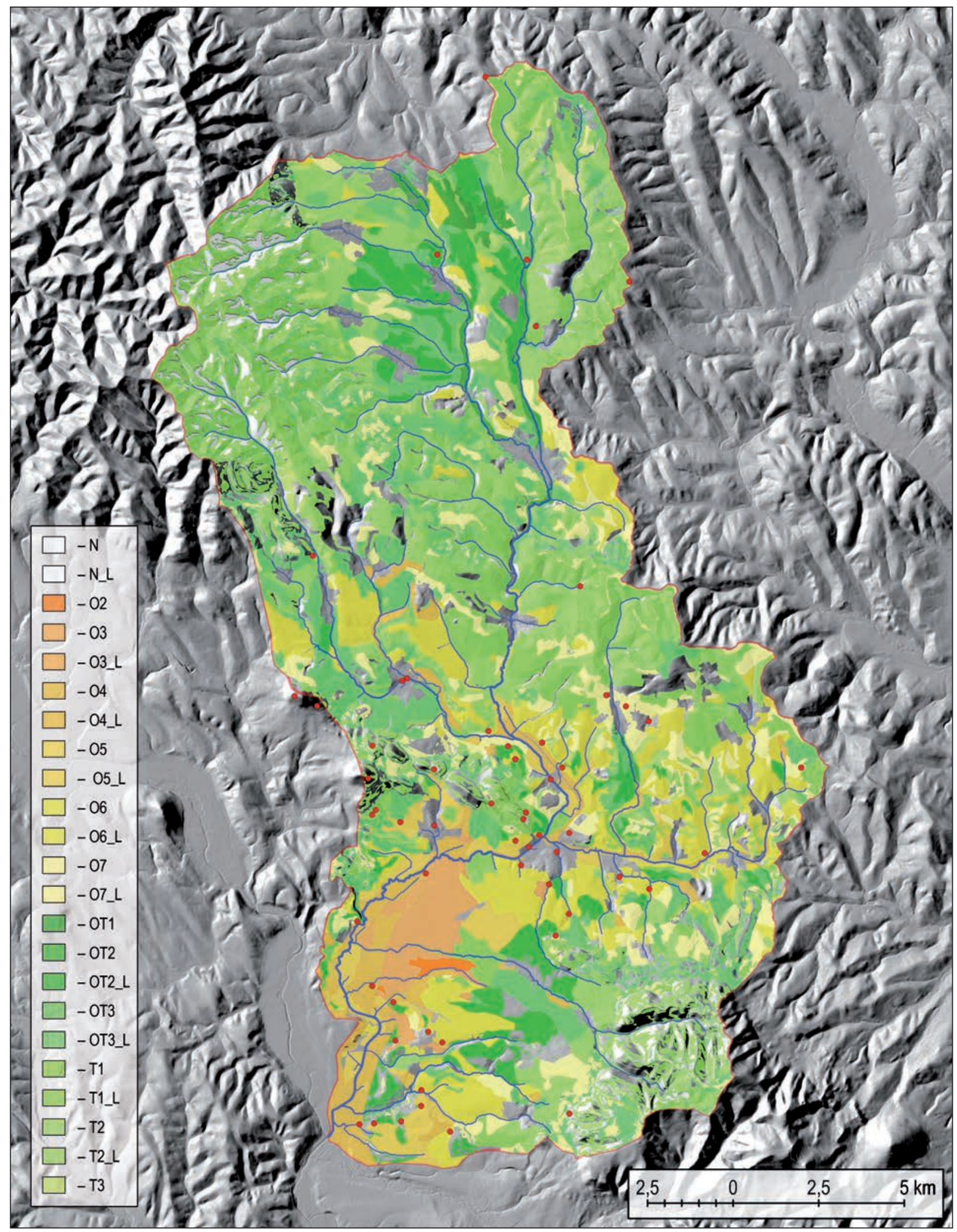

Obr. 3. Mapa pôdneho krytu sledovaného územia. O2 - vysoko produkčné orné pôdy; O3 a O3_L - velmi produkčné orné pôdy; O4 a O4_L - produkčné orné pôdy; O5 a O5_L - stredne produkčné orné pôdy; O6 a O6_L - menej produkčné orné pôdy; O7 a O7_L - málo produkčné orné pôdy; OT1 - stredne produkčné polia a produkčné trávne porasty; OT2 a OT2_L-menej produkčné polia a produkčné trávne porasty; OT3 a OT3_L-málo produkčné polia a produkčné trávne porasty; T1 a T1_L - produkčné trvalé trávne porasty; T2 a T2_L - menej produkčné trvalé trávne porasty; T3 - málo produkčné trvalé trávne porasty; N a N_L - pre agroekosystémy nevhodné územia. Symbol L v kódoch značí pôdy v lesoch z pôdnej mapy (podl’a Džatko 2002, tab. 5; mapový podklad ŠÚGDŠ, VÚPOP a ÚGKK SR). 


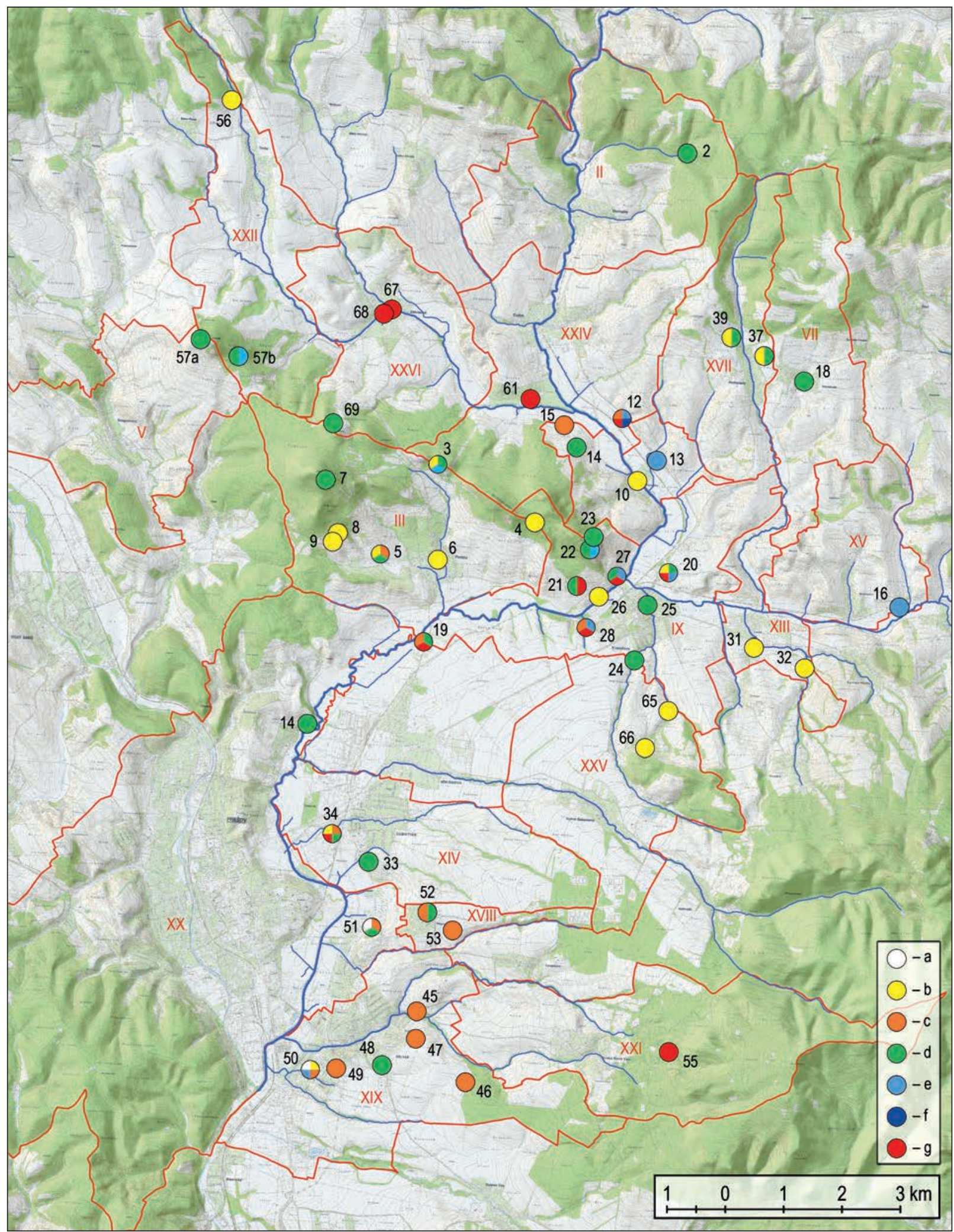

Obr. 4. Osídlenie povodia Sekčova od paleolitu po dobu rímsku, južná čast'. Arabské čísla na mape zodpovedajú poradovým číslam komponentov v tabele 2. Rímske číslovanie katastrov sa zhoduje s číslovaním na obrázku 1. Legenda: a - paleolit; $\mathrm{b}$ - neolit; c - eneolit; $\mathrm{d}$ - doba bronzová; e - staršia doba železná; $\mathrm{f}$ - mladšia doba železná; $\mathrm{g}$ - doba rímska. Numerické označenie lokalít sa zhoduje s ich značením v tabele 2 (mapový podklad ÚGKK SR). 


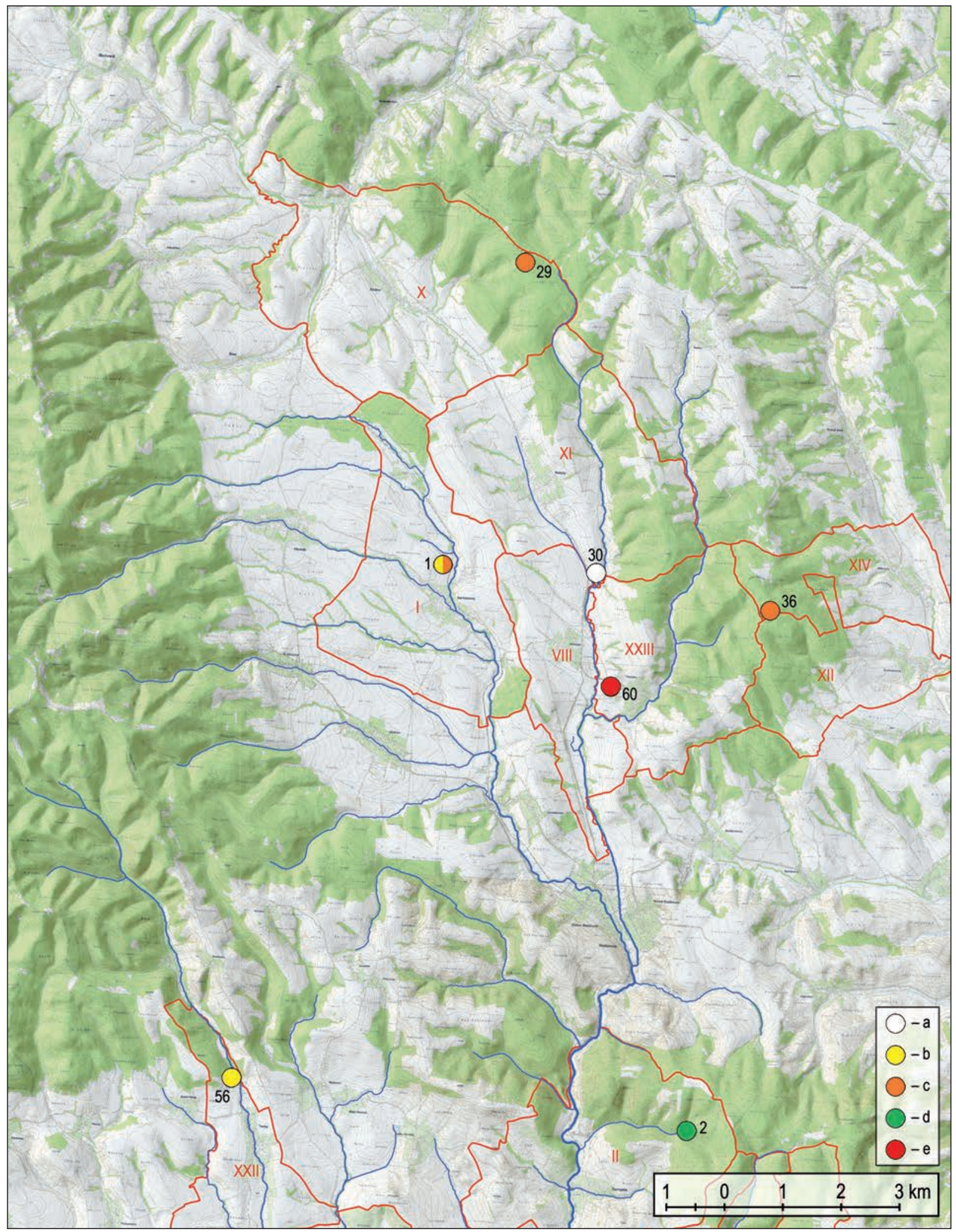

Obr. 5. Osídlenie povodia Sekčova od paleolitu po dobu rímsku - severná čast'. Arabské čísla na mape zodpovedajú poradovým číslam komponentov v tabele 2. Rímske číslovanie katastrov sa zhoduje s číslovaním na obrázku 1. Legenda: a - paleolit; b - neolit; c - eneolit; d - doba bronzová; e -doba rímska. Numerické označenie lokalít sa zhoduje s ich značením v tabele 2 (mapový podklad ÚGKK SR). 


\begin{tabular}{|c|c|c|c|c|c|c|c|c|c|c|c|c|c|c|c|c|c|c|c|c|c|c|c|c|}
\hline 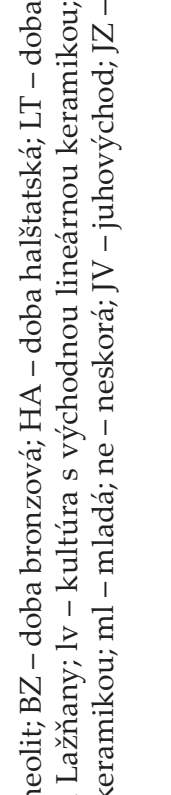 & 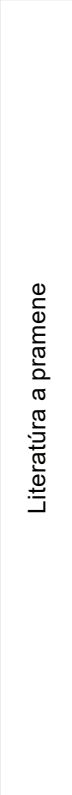 & 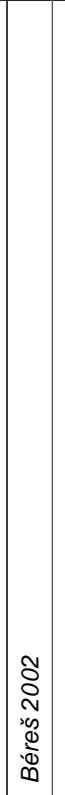 & 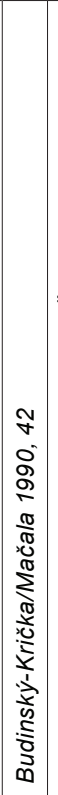 & 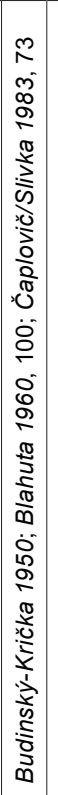 & 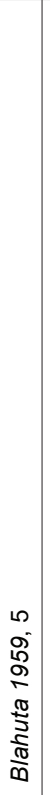 & 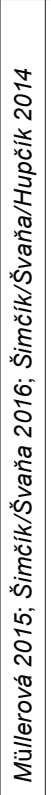 & 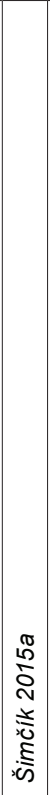 & 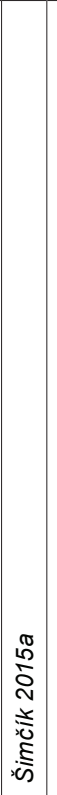 & 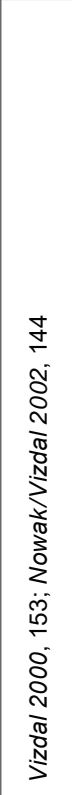 & 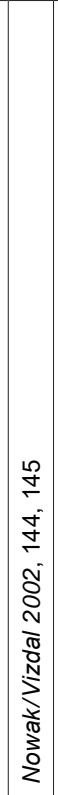 & 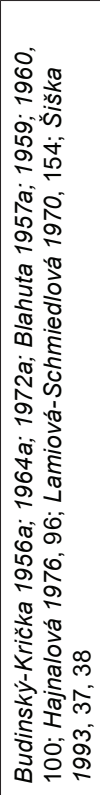 & 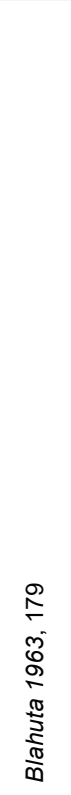 & 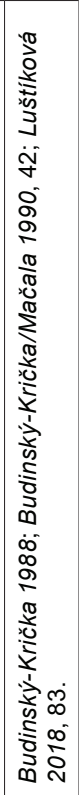 & 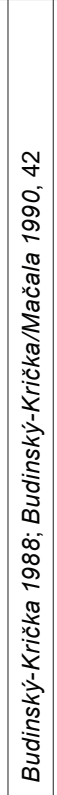 & 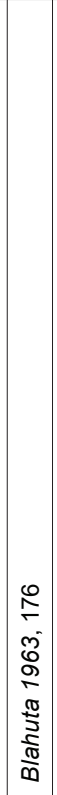 & 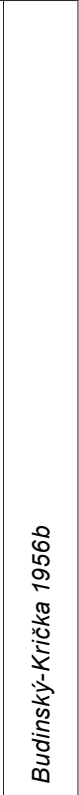 & 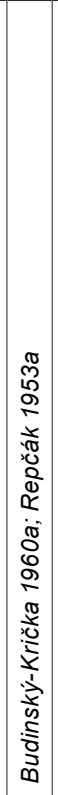 & 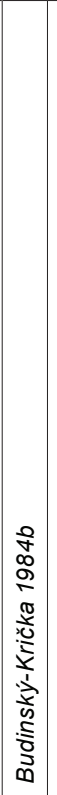 & 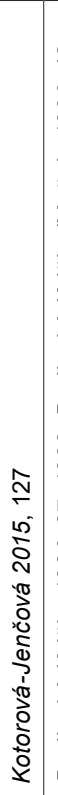 & 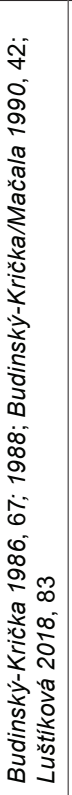 & 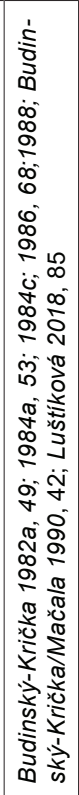 & 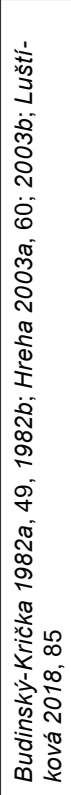 & 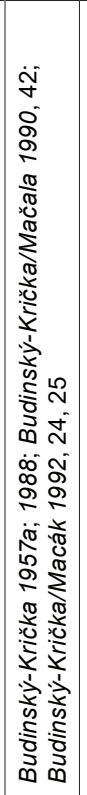 & 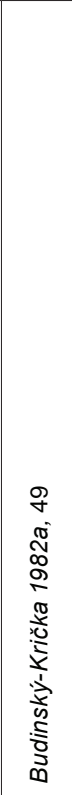 \\
\hline 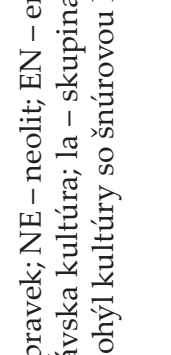 & 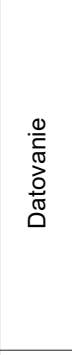 & 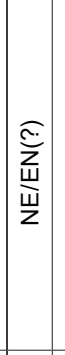 & $\begin{array}{c}\bar{\varepsilon} \\
N \\
\infty\end{array}$ & 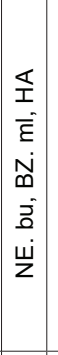 & $\begin{array}{l}\vec{\partial} \\
\dot{u} \\
z\end{array}$ & 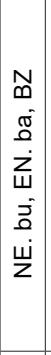 & 岁 & $\begin{array}{c}\bar{\varepsilon} \\
N \\
\infty\end{array}$ & 岁 & $\stackrel{\mathrm{u}}{\mathrm{z}}$ & 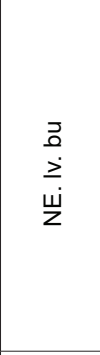 & 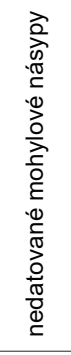 & $\begin{array}{l}\sqcup \\
\square \\
\mathbb{x} \\
\vec{\alpha} \\
\vec{\alpha} \\
\underline{\sigma} \\
\dot{\vec{u}}\end{array}$ & 㜽 & $\begin{array}{l}N \\
\infty\end{array}$ & z & 㜽 & 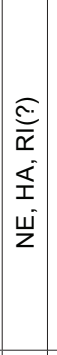 & $\begin{array}{c}\mathscr{D} \\
\stackrel{1}{N} \\
\mathbb{\infty}\end{array}$ & $\begin{array}{l}\bar{x} \\
\bar{\varepsilon} \\
N \\
\infty \\
N \\
N \\
\dot{W} \\
\dot{W}\end{array}$ & 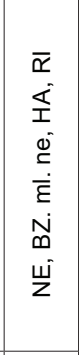 & $\begin{array}{l}\bar{\alpha} \\
\bar{\varepsilon} \\
N \\
\tilde{\infty}\end{array}$ & $\begin{array}{l}\mathbb{1} \\
\text { I } \\
\text { N } \\
\text { N }\end{array}$ & $\begin{array}{l}\bar{\varepsilon} \\
N \\
\infty\end{array}$ \\
\hline $\begin{array}{l}1 \\
0 \\
0 \\
0\end{array}$ & 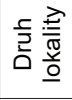 & $\bar{\omega}$ & $\bar{\omega}$ & $\bar{\omega}$ & $\bar{\omega}$ & $\bar{\omega}$ & $\bar{\omega}$ & $\bar{\omega}$ & $\bar{\omega}$ & $\bar{\omega}$ & $\bar{\omega}$ & $\bar{\omega}$ & '̄ & $\bar{\omega}$ & ঃ & $\bar{\omega}$ & $\bar{\omega}$ & $\bar{\omega}$ & $\bar{\omega}$ & $\bar{\omega}$ & $\bar{\omega}$ & $\bar{\omega}$ & $\bar{\omega}$ & $\bar{\omega}$ \\
\hline 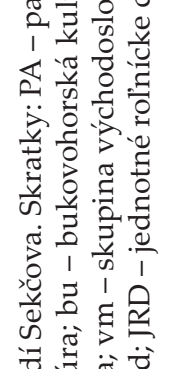 & $\begin{array}{l}\frac{\pi}{0} \\
\frac{0}{0} \\
0\end{array}$ & 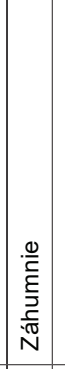 & 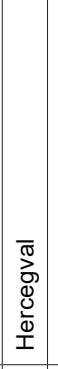 & 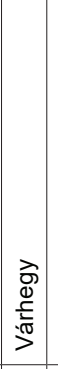 & 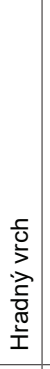 & 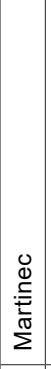 & 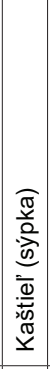 & 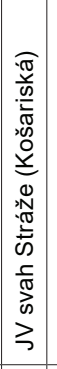 & 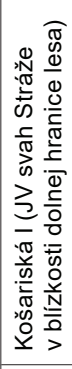 & 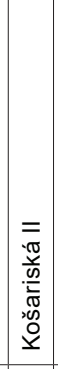 & 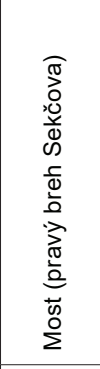 & 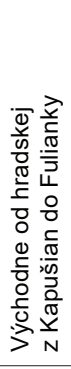 & 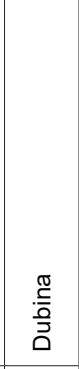 & 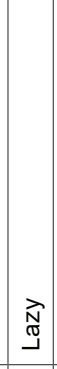 & 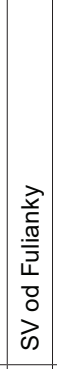 & 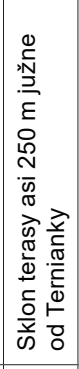 & 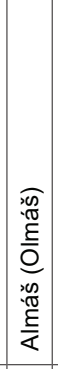 & 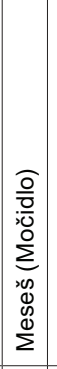 & 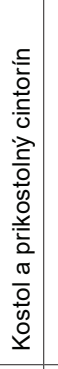 & 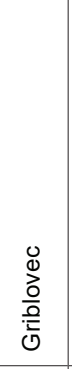 & 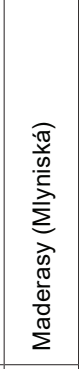 & 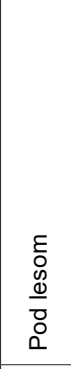 & 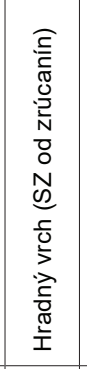 & 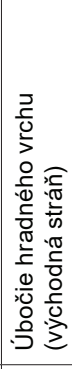 \\
\hline 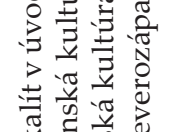 & 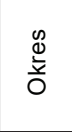 & 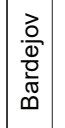 & 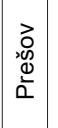 & 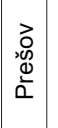 & 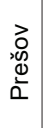 & 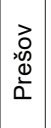 & 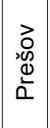 & 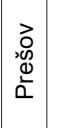 & 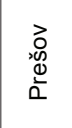 & 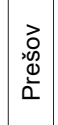 & 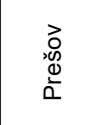 & 家 & 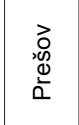 & 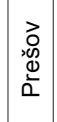 & 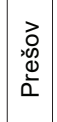 & 离 & 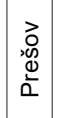 & 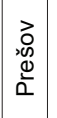 & 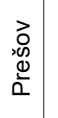 & 总 & 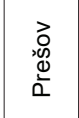 & 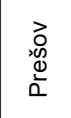 & 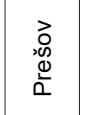 & 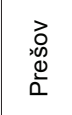 \\
\hline 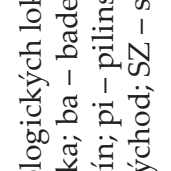 & 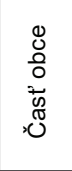 & 1 & 1 & 1 & 1 & 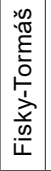 & 1 & 1 & 1 & 1 & 1 & 1 & 1 & 1 & 1 & 1 & 1 & 1 & 1 & 1 & 1 & 1 & 1 & 1 \\
\hline $\begin{array}{ll}0 & 0 \\
0 & 0 \\
1 & 1 \\
1 & 0\end{array}$ & $\begin{array}{l}0 \\
\mathbb{0} \\
0 \\
0\end{array}$ & 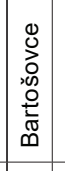 & 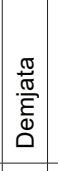 & 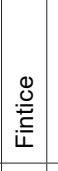 & 总 & 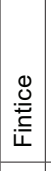 & 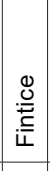 & 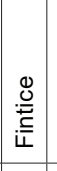 & 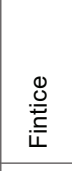 & 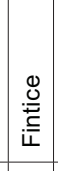 & 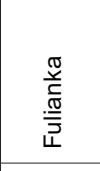 & 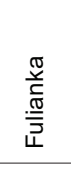 & 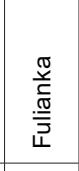 & 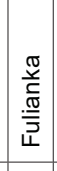 & 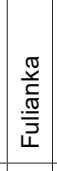 & 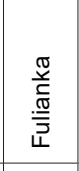 & 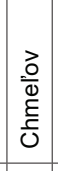 & 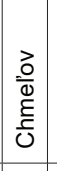 & 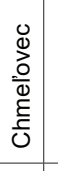 & 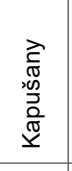 & 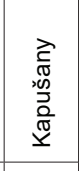 & 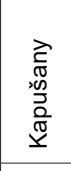 & 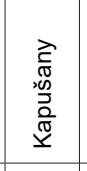 & 宽 \\
\hline . 11 & 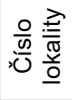 & 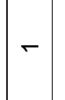 & $\sim$ & $m$ & $\nabla$ & L & 0 & 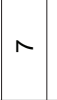 & $\infty$ & a & ㅇ & $\exists$ & $\approx$ & $\underset{\sim}{\mathscr{m}}$ & ন & $\stackrel{\sim}{\sim}$ & $\stackrel{0}{9}$ & $\neg$ & $\stackrel{\infty}{\rightarrow}$ & $\stackrel{9}{9}$ & N & $\vec{N}$ & N & $\stackrel{N}{\sim}$ \\
\hline
\end{tabular}




\begin{tabular}{|c|c|c|c|c|c|c|c|c|c|c|c|c|c|c|c|c|c|c|c|c|c|c|c|}
\hline 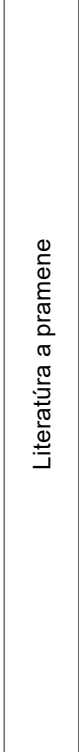 & 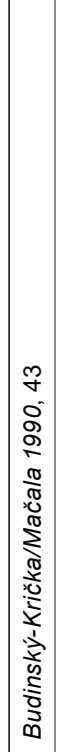 & 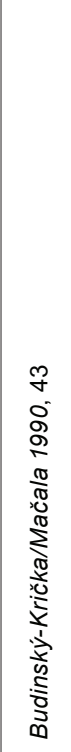 & 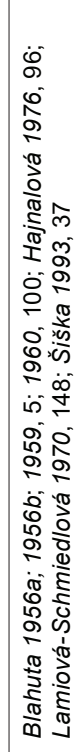 & 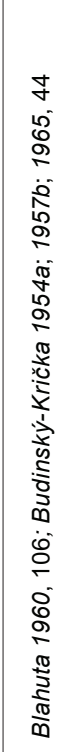 & 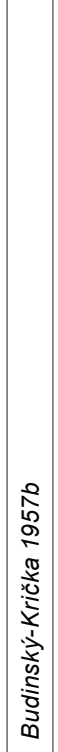 & 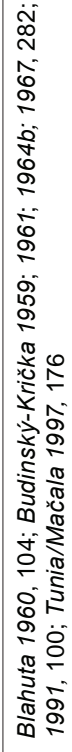 & 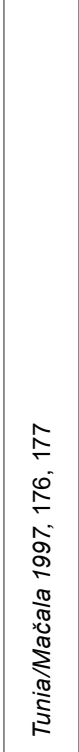 &  & 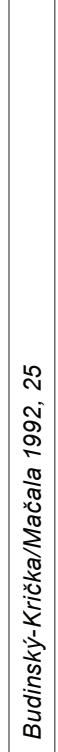 & 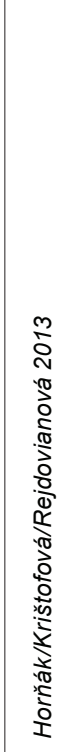 & 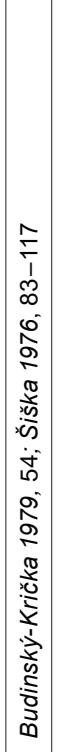 & 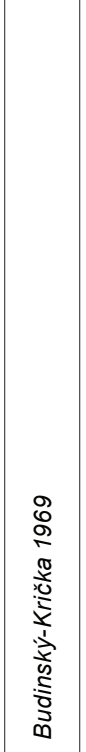 & 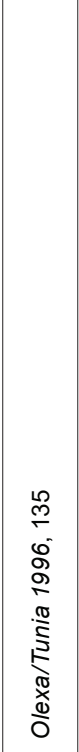 & 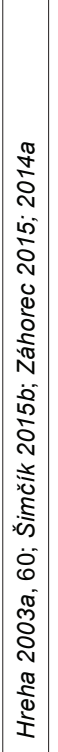 & 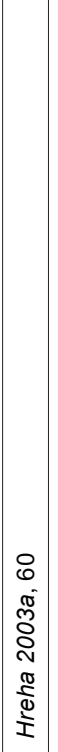 & 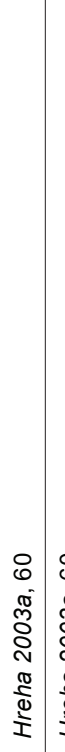 & 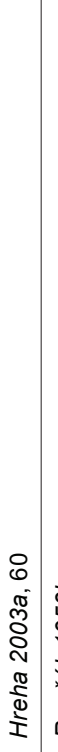 & 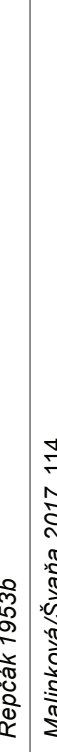 & 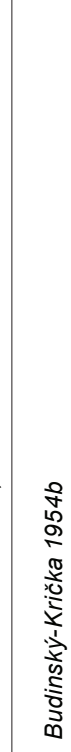 & 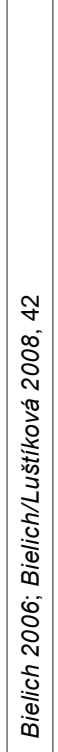 & 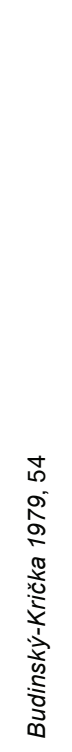 & 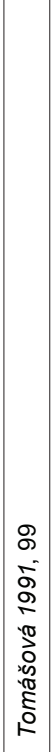 & 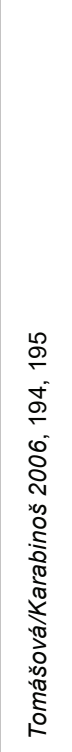 \\
\hline 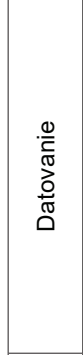 & \begin{tabular}{|c|}
$\bar{\varepsilon}$ \\
$N$ \\
$\Phi$
\end{tabular} & $\begin{array}{l}\bar{\varepsilon} \\
\mathcal{N}\end{array}$ & 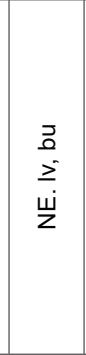 & $\begin{array}{l}\bar{\alpha} \\
\bar{x} \\
\dot{X} \\
\dot{\bar{\varepsilon}} \\
N \\
\infty\end{array}$ & $\mid \begin{array}{l}\bar{x} \\
\bar{x} \\
\bar{z} \\
\bar{u}\end{array}$ & $\begin{array}{l}\xi \\
\sum \\
\dot{\Psi}\end{array}$ & 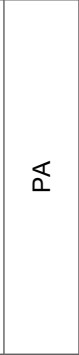 & $\begin{array}{l}\vec{z} \\
\dot{u} \\
\dot{z}\end{array}$ & $\begin{array}{l}\geq \\
\dot{u} \\
\mathrm{z}\end{array}$ & 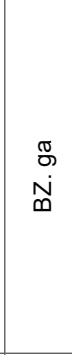 & 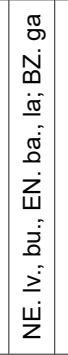 & $\begin{array}{l}\bar{z} \\
\dot{z} \\
\dot{z} \\
\underline{z}\end{array}$ & $\begin{array}{l}\xi \\
\xi \\
\dot{u}\end{array}$ & 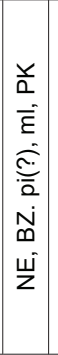 & 文 & $\begin{array}{l}N \\
\infty \\
\dot{u} \\
z\end{array}$ & $\frac{x}{0}$ & $\frac{x}{a} \quad \frac{x}{0}$ & $\frac{x}{a}$ & $\begin{array}{l}\tilde{N} \\
\tilde{z} \\
\underline{z} \\
\underline{u}\end{array}$ & $\begin{array}{l}\text { o } \\
\text { o } \\
\text { ये }\end{array}$ & u & zu \\
\hline 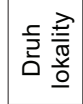 & $\bar{\infty}$ & $\bar{\omega}$ & $\bar{\omega}$ & $\begin{array}{l}\bar{\omega} \\
\overline{8} \\
\overline{0}\end{array}$ & $\bar{\omega}$ & $\stackrel{\circ}{\circ}$ & $\bar{\omega}$ & $\bar{\omega}$ & $\bar{\omega}$ & $\bar{\omega}$ & $\bar{\omega}$ & $\bar{\omega}$ & 음 & $\bar{\omega}$ & $\bar{\omega}$ & $\bar{\infty}$. & $\bar{\omega}$ & \begin{tabular}{|c|c|}
$\overline{0}$ &.$\overline{0}$
\end{tabular} & $\bar{\omega}$ & $\bar{\omega}$ & $\bar{\omega}$ & $\bar{\omega}$ & $\bar{\omega}$ \\
\hline 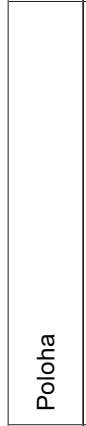 & 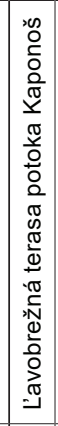 & 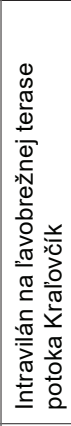 & 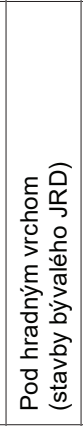 & 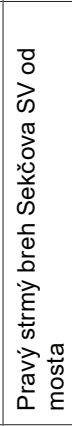 & 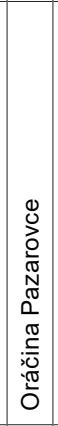 & 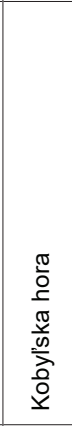 & 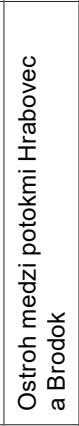 & 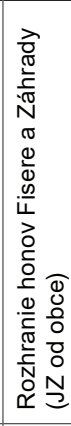 & 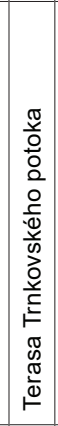 & 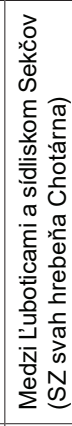 & 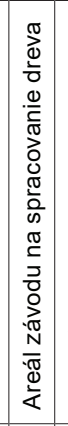 & 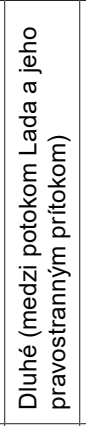 & 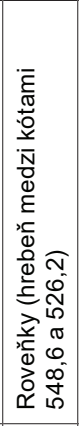 & 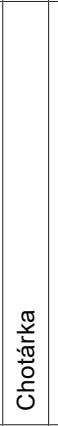 & $\begin{array}{l}\text { 충 } \\
0.00 \\
0 \\
0\end{array}$ & 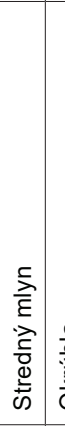 & $\begin{array}{l}\frac{\pi}{2} \\
\frac{5}{5} \\
\frac{5}{0}\end{array}$ & 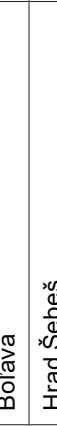 & 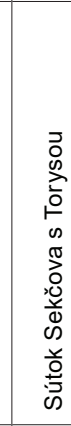 & 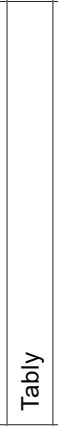 & 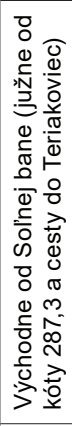 & 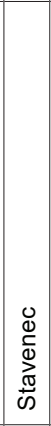 & 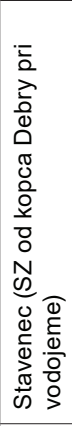 \\
\hline $\begin{array}{l}\mathscr{\mathscr { U }} \\
\frac{\mathscr{\omega}}{\mathrm{z}}\end{array}$ & 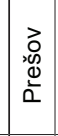 & 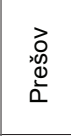 & 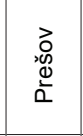 & 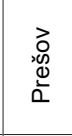 & 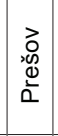 & 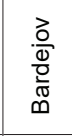 & 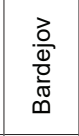 & 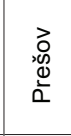 & 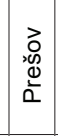 & 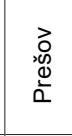 & 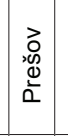 & 兑 & 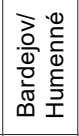 & 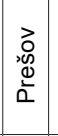 & 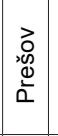 & 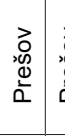 & 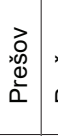 & 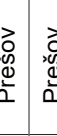 & 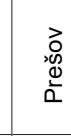 & 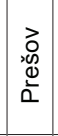 & 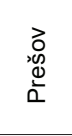 & 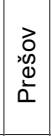 & 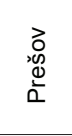 \\
\hline 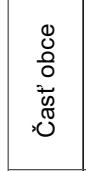 & 1 & 1 & 1 & 1 & 1 & 1 & 1 & 1 & 1 & 1 & 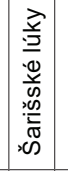 & 1 & 1 & 1 & 1 & 1 & 1 & 1 & 1 & 官 & 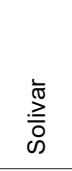 & ம & 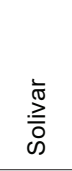 \\
\hline
\end{tabular}




\begin{tabular}{|c|c|c|c|c|c|c|c|c|c|c|c|c|c|c|c|c|c|c|c|c|c|c|c|}
\hline 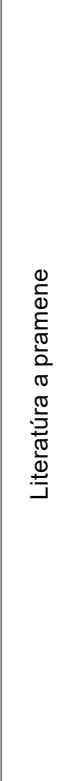 & 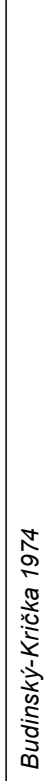 & 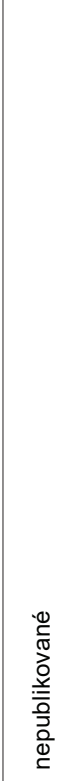 & 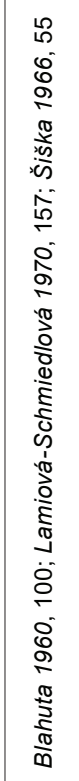 & 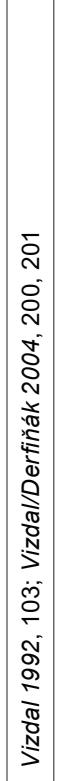 & 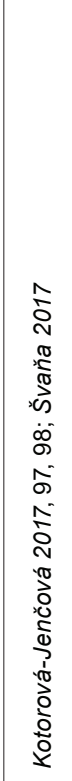 & 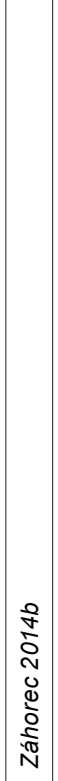 & 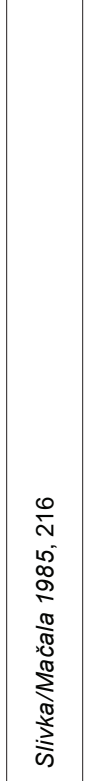 & 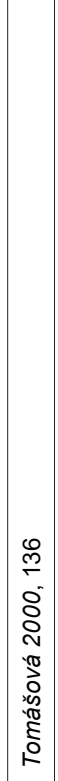 & 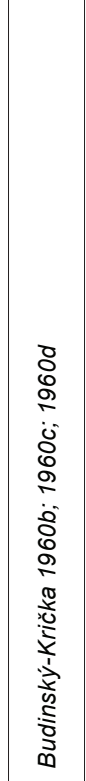 & 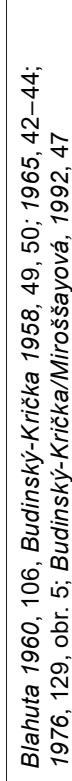 & 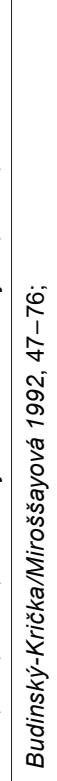 & 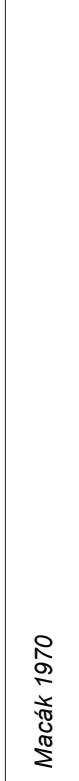 & 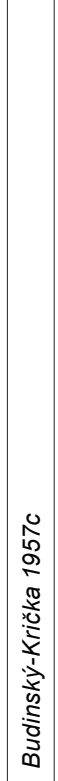 & 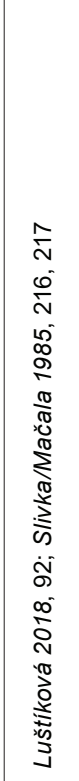 & 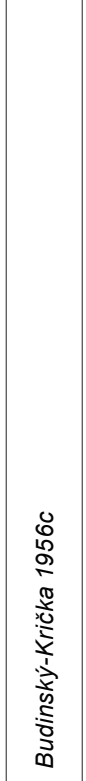 & 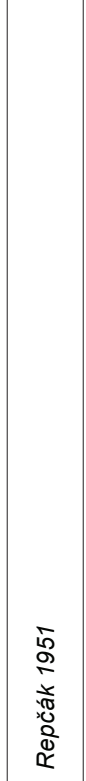 & 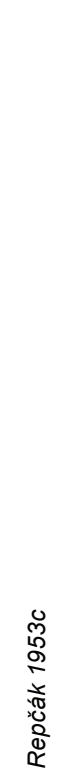 & 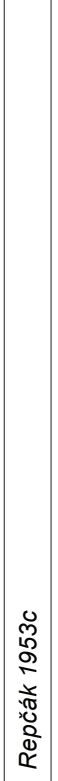 & 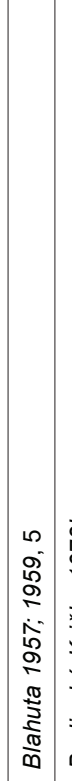 & 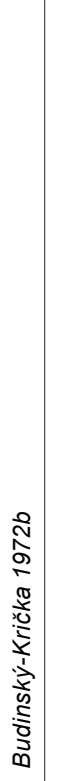 & 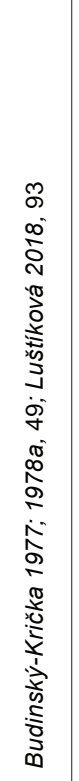 & 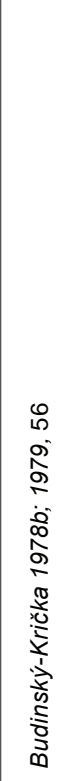 & 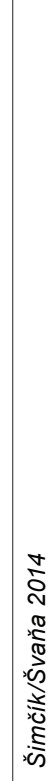 \\
\hline 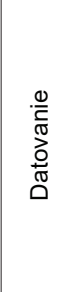 & \begin{tabular}{|l}
$\tilde{D}$ \\
J \\
N
\end{tabular} & $\begin{array}{l}\stackrel{0}{0} \\
\stackrel{2}{u}\end{array}$ & 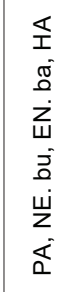 & $\begin{array}{l}N \\
\infty \\
Z Z \\
u \\
\Sigma \\
\Delta \\
\Sigma\end{array}$ & $\begin{array}{l}\bar{E} \\
N \\
\infty \\
\Phi \\
\Omega \\
\sum_{W}\end{array}$ & 旁 & $\frac{x}{a}$ & $\begin{array}{c}\bar{\varepsilon} \\
\overline{\dot{\alpha}}\end{array}$ & 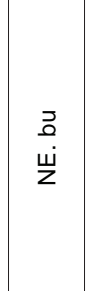 & $\begin{array}{l}\vec{E} \\
N \\
\mathbb{N}\end{array}$ & $\begin{array}{l}\mathbb{I} \\
\vec{E} \\
\vec{E} \\
\mathbb{N}\end{array}$ & $\frac{x}{a}$ & 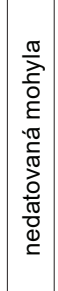 & $\begin{array}{l}\bar{\alpha} \\
\underline{a}\end{array}$ & $\bar{\alpha}$ & $\frac{x}{a}$ & $\frac{x}{a}$ & $\frac{x}{0}$ & \begin{tabular}{|l}
$z$ \\
$b$ \\
$\dot{d}$ \\
$z$
\end{tabular} & $\begin{array}{l}\geq \\
\stackrel{u}{z}\end{array}$ & $\begin{array}{l}\bar{\varepsilon} \\
\overline{\dot{\alpha}}\end{array}$ & $\begin{array}{l}\bar{\varepsilon} \\
\overline{\dot{\alpha}}\end{array}$ & $\stackrel{N}{N}$ \\
\hline 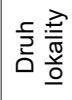 & $\bar{\omega}$ & $\bar{\omega}$ & $\bar{\omega}$ & $\bar{\omega}$ & $\bar{\omega}$ & $\bar{\omega}$ & $\bar{\omega}$ & $\stackrel{\circ}{\varrho}$ & $\bar{\omega}$ & $\bar{\omega}$ & $\bar{\omega}$ & $\bar{\omega}$ & 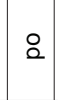 & $\bar{\omega}$ & $\bar{\omega}$ & के & $\bar{\omega}$ & $\bar{\omega}$ & $\bar{\omega}$. & $\bar{\omega}$ & $\bar{\omega}$ & $\bar{\omega}$ & $\bar{\omega}$ \\
\hline $\begin{array}{l}\frac{\pi}{0} \\
\frac{0}{0} \\
0\end{array}$ & 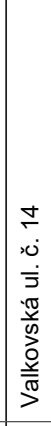 & 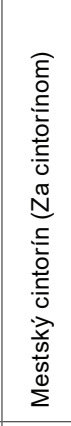 & 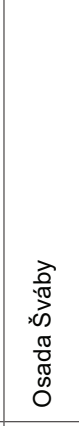 & 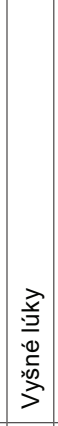 & 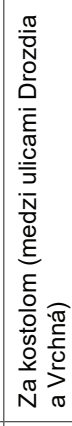 & 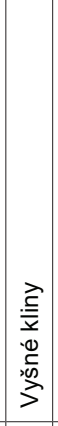 & 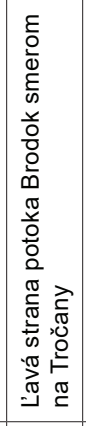 & 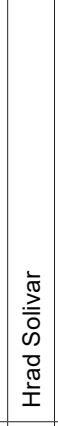 & 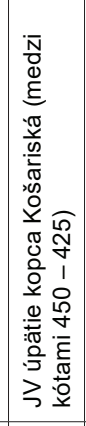 & 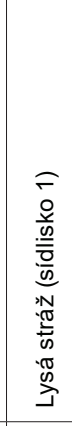 & 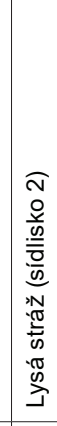 & 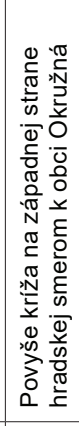 & 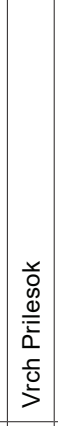 & 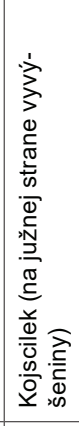 & 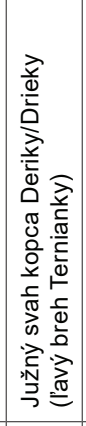 & 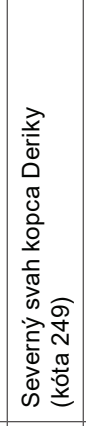 & 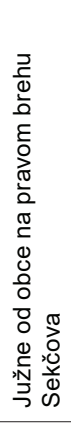 & 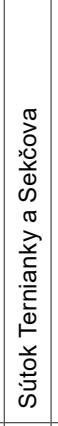 & 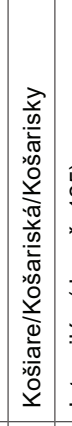 & 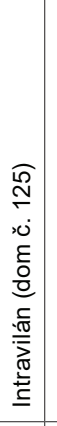 & 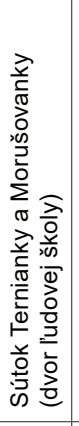 & 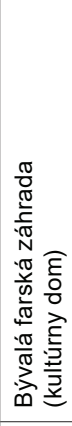 & $\mid$ \\
\hline 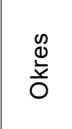 & 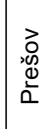 & 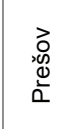 & 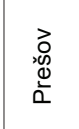 & 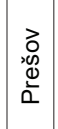 & 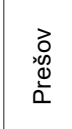 & 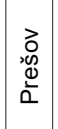 & $\begin{array}{l}\frac{\overrightarrow{0}}{\bar{\Phi}} \\
\frac{0}{\overline{0}} \\
\bar{\infty}\end{array}$ & 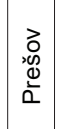 & 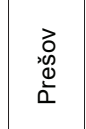 & 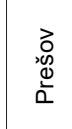 & 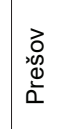 & 总 & 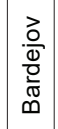 & 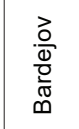 & 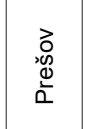 & 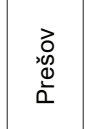 & 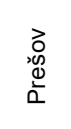 & 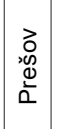 & 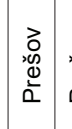 & 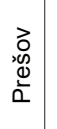 & 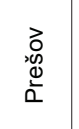 & 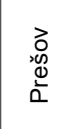 & 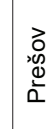 \\
\hline 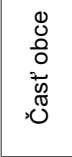 & 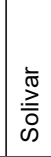 & 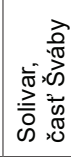 & 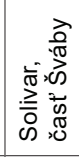 & 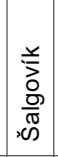 & 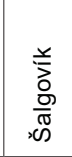 & 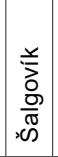 & 1 & 1 & 1 & 1 & 1 & 1 & 1 & 1 & 1 & 1 & 1 & 1 & 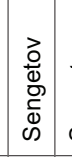 & 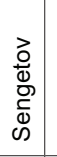 & 1 & 1 & 1 \\
\hline $\begin{array}{l}\text { ष } \\
\text { Oे }\end{array}$ & 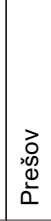 & 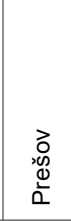 & 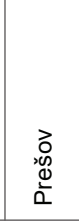 & 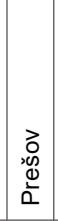 & 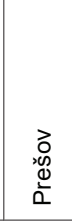 & 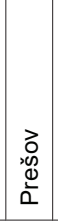 & 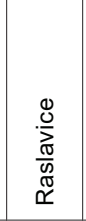 & 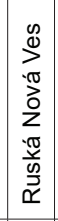 & مِ & 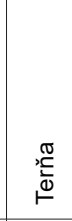 & 苋芯 & $\begin{array}{l}\text { के } \\
\text { 总 } \\
\text {. }\end{array}$ & 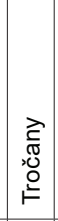 & 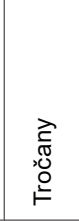 & $\frac{\sqrt{0}}{\overline{0}}$ & 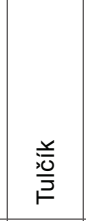 & 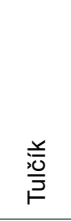 & 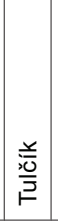 & 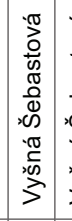 & 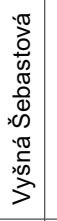 & 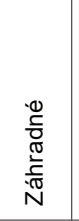 & 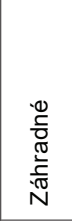 & 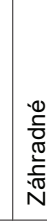 \\
\hline 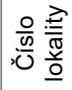 & $\stackrel{\infty}{\stackrel{\infty}{~}}$ & g & is & $\vec{n}$ & ก๊ & ڤొ & 占 & 吕 & 吕 & $\overbrace{}^{\pi}$ & 官 & $\stackrel{\infty}{\circ}$ & 吕 & 8 & $\overrightarrow{0}$ & $\widetilde{\widetilde{O}}$ & 8 & 8 & 㟔 & 8 & $\hat{\theta}$ & $\stackrel{\infty}{\circ}$ & 8 \\
\hline
\end{tabular}




\section{METÓDA}

Cielom tejto štúdie je pokus vytvorit model sídelných štruktúr vybraných pravekých, resp. protohistorických období v povodí Sekčova. Ako sme už uviedli, východiskom tvorby modelu boli publikované i nepublikované výstupy z archeologických výskumov či prieskumov. Údaje zhromaždené v databáze sa preniesli do GIS-u (pracovali sme so softvérom QGIS, resp. SAGA). Túto základnú informačnú vrstvu (archeologické dáta) sme doplnili o sekundárnu informačnú vrstvu priestorových a environmentálnych dát, ktoré sme extrahovali z rôznych vektorových či mapových vrstiev v zmienenom GIS-e. Z nich ako základnú je potrebné uviest’ digitálny výškový model (DMR, DEM) Slovenska v rozlíšení rastru 10 x 10 m, ktorý Archeologickému ústavu na použitie poskytol Štátny geologický ústav Dionýza Štúra (d’alej ŠGÚDŠ). Pri triedení lokalít pracujeme s priestorovými dátami (nadmorská výška, orientácia, sklon svahu, prevýšenie nad okolím, drsnost'). V GIS-e sme vytvorili aj vrstvu potenciálnych vodných tokov a vzdialenost k nim sme zistovali metódou „least

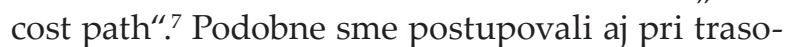
vaní hlavného komunikačného koridoru, podla nás by mal viest' najschodnejším terénom po dne údolia. Líniu vypočítanú zmieneným algoritmom sme vzhl'adom na šírku údolia rozšírili na 500 m široký pruh, aby sme pokryli viaceré varianty možných komunikačných línií. Nepriame vzdialenosti lokalít ku komunikačnému koridoru sme merali k okrajom tohto pruhu.

Charakter terénu v okolí komponentu reprezentujú tri údaje: percentuálne zastúpenie jednotlivých kategórií svahov ${ }^{8} \mathrm{v}$ polygónoch s polomerom $150 \mathrm{~m}$ okolo daného bodu (predpokladaný areál aktivity), $500 \mathrm{~m}$ okolo bodu (predpokladaný sídelný areál) ${ }^{9}$ a priemerná hodnota indexu drsnosti v okruhu
150 a $500 \mathrm{~m}$. Do vrstvy priestorových dát patrí aj údaj o hustote osídlenia a vzdialenosti medzi lokalitami, ktorú sme vypočítali prostým vydelením počtu komponentov príslušného obdobia rozlohou plôch so sklonom do 3 až $10^{\circ}$ na skúmanom území. ${ }^{10}$ Vzdialenosti medzi komponentmi sa počítali opät v GIS-e predvoleným algoritmom (metódou najbližšieho suseda).

Sekundárnu vrstvu „Environmentálne dáta“ predstavuje skladba polnohospodárskych pôd v predpokladaných sídelných areáloch evidovaných komponentov. V tomto prípade sme ako polomer polygónu opät zvolili okruh s $500 \mathrm{~m}$ polomerom. ${ }^{11}$ Pri posudzovaní výskytu pôdnych typov v okolí nálezísk sme použili mapu bonitovaných pôdno-ekologických jednotiek (d’alej BPEJ), ktoré možno zoskupit do 14 vyšších akostných tried, teda do tzv. typologicko-produkčných kategórií (Džatko 2002, tab. 5; príloha 1). ${ }^{12}$ Nevýhodou mapy je, že nezahŕňa intravilány obcí a zalesnené územie. Kedž̌e niektoré spracovávané lokality sa nachádzajú na zalesnenom území, napokon sme sa rozhodli prázdne plochy mapy BPEJ vyplnit omnoho schematickejšou mapou pôdnych typov v mierke 1 : 400 000. Takto získané vel'ké a schematizované polygóny lesných pôdnych typov sme však rozdelili aspoň podla svahovitosti (ide o jedno z kritérií delenia BPEJ). Pracovne sme ich roztriedili na typologicko-produkčné kategórie (d’alej TPK) podla charakteristiky príbuzných BPEJ v okolí. V kóde ich na odlíšenie od vlastných TPK označujeme písmenom L. Pri analýze pôdneho krytu pracujeme bud' na úrovni BPEJ, alebo na úrovni TPK a do úvahy berieme percentuálne zastúpenie daných kategórií na celkovej rozlohe polnohospodárskej pôdy v predpokladanom sídelnom areáli.

Výsledky získané popísaným postupom štatisticky testujeme. V prvom kroku sa pokúšame lokality jednotlivých období zoskupit podla vybratých parametrov a v druhom testovat', či sa toto roztriedenie

\footnotetext{
7 Pri roztriedení takto vytvorenej siete na 5 stupňov podla výdatnosti sme brali do úvahy vzdialenost’ až k tokom stupňa 2.

81 - rovina bez plošnej vodnej erózie $\left(0^{\circ}-1^{\circ}\right) ; 2$ - rovina s možnostou plošnej vodnej erózie $\left(1^{\circ}-3^{\circ}\right)$; mierny svah $\left(3^{\circ}-7^{\circ}\right)$; stredný svah $\left(7^{\circ}-12^{\circ}\right)$; výrazný svah $\left(12^{\circ}-17^{\circ}\right)$; príkry svah $\left(17^{\circ}-25^{\circ}\right)$; zráz (nad $25^{\circ}$; Džatko/Sobecká a kol. 2009, 39).

9 Postup sme zvolili podla literatúry (Lieskovský a i. 2015, 89; Neustupný 2007, 36, 37).

${ }^{10} \mathrm{Na}$ takto sklonených plochách sa totižto podl’a výsledkov súhrnnej štatistiky parametru „Sklon“ vyskytuje väčšina evidovaných lokalít, ktorá reprezentuje komponenty s výskytom v rozpätí percentilov 25-75\% dotknutého parametru.

${ }^{11}$ Okruh sme zámerne obmedzili na pomerne malú plochu, aby sa zvýraznili prípadné rozdiely medzi jednotlivými lokalitami. Vychádzame z hypotézy, že sídliskovou stratégiou kopaničiarskych či rolníckych komunít by malo byt usadzovat’ sa čo najbližšie k ostrovom úrodných pôd. To však samozrejme neznamená, že by nevyužívali všetky dostupné úrodné plochy (povedzme v polhodinovej vzdialenosti). Avšak pri relatívne malej rozlohe sekčovského údolia a zhlukovaniu evidovaných lokalít by sa pri väčšom polomere sledované areály prekrývali a rozdiely by sa nutne stierali.

12 Podla citovanej monografie (Džatko 2002, 20, tab. 5) možno pôdy triedit na potenciálne orné pôdy (O), striedavé polia (OT1), trvalé trávnaté porasty $(\mathrm{T})$ a nevhodné pôdy $(\mathrm{N})$, ktoré sa delia na viacero subtypov, tieto vyjadrujú relatívne rozdiely produkčného potenciálu BPEJ v rámci príslušných typov: O1 - najprodukčnejšie orné pôdy, $\mathrm{O} 2$ - vysoko produkčné orné pôdy, O3 - vel'mi produkčné orné pôdy, O4 - produkčné orné pôdy, O5 - stredne produkčné orné pôdy, O6 - menej produkčné orné pôdy, O7 - málo produkčné orné pôdy. Podobne, ale iba na tri subtypy, sa delia aj striedavé polia (OT1 - 3) a trávne porasty $(\mathrm{T} 1-3)$.
} 

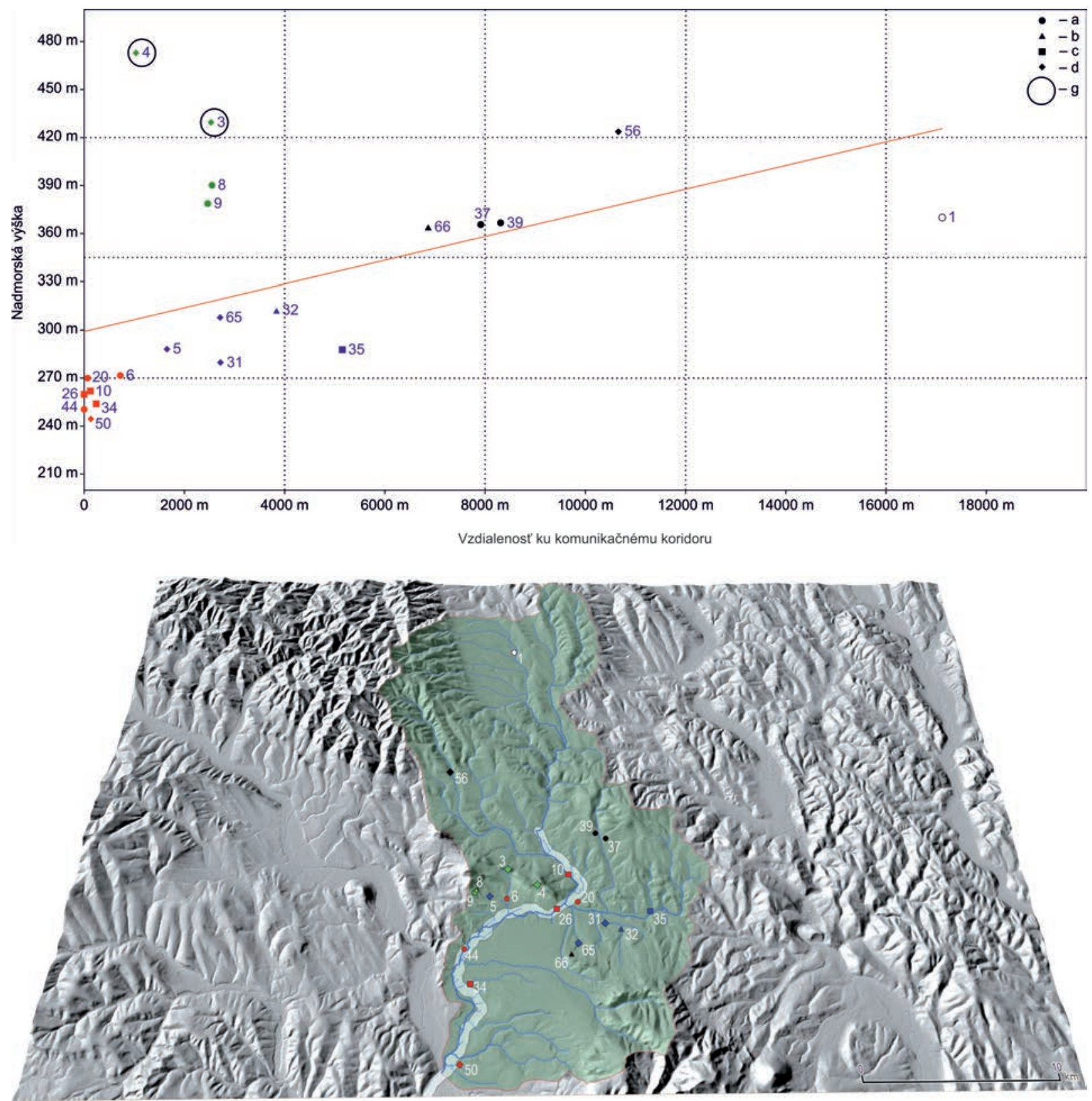

Obr. 6. Model zonácie neolitického osídlenia v povodí Sekčova. 1 - porovnanie osídlenia vo vztahu k nadmorskej výške a vzdialenosti od komunikačného koridoru; 2 - vyobrazenie výsledkov zonácie na reliéfnej mape. Legenda: a - neurčené zaradenie; b-kultúra s východnou lineárnou keramikou; $\mathrm{c}$-kultúra s východnou lineárnou keramikou a bukovohorská kultúra; d - bukovohorská kultúra; g - výšinné sídlisko. Farby symbolov: červená - zóna NE1; modrá - zóna NE2; zelená - zóna NE3; čierna - zóna NE4; biela - zóna NE5. Numerické označenie lokalít sa zhoduje s ich značením v tabele 2.

prejavuje aj v iných rozmeroch. Východiskom pre spomenuté zoskupenie bola klasifikácia nálezísk podla situovania $\mathrm{v}$ teréne, preto ich polohu vztahujeme na dve pomocné, s priestorom pevne zviazané „osi“, ktoré sú tvorené parametrami. Tie by mali korelovat', totiž s nadmorskou výškou a vzdialenos- tou od hlavného komunikačného koridoru. ${ }^{13} \mathrm{Na}-$ pokon, význam uvedených premenných potvrdila aj analýza hlavných komponentov (dalej PCA). Ich koreláciu testujeme lineárnou regresiou, výsledkom je vytriedenie viacerých skupín, zón, na príslušných diagramoch vcelku dobre rozlísitelných (obr. 6:1;7:1).

${ }^{13}$ Práve z tohto dôvodu nepovažujeme na základné triedenie vhodný napr. parameter „Vzdialenost’ k vodnému zdroju“, ked’že voda je zjavne podmienkou (aj ked’ nie vždy úplne nevyhnutnou) prítomnosti dlhodobého osídlenia (t. j. takého, ktoré zanechá archeologicky postihnutelné zvyšky), vzdialenost k jej zdroju prakticky nezávisí od situovania lokality v jednotlivých krajinných zónach. Naopak jej neprítomnost̉ v okolí náleziska už signalizuje zvláštny typ osídlenia (napr. výšinné sídliská). 
Tabela 3. Taxonomické členenie geomorfologických jednotiek severovýchodného Slovenska v povodí Sekčova.

\begin{tabular}{|l|l|l|l|l|}
\hline \multicolumn{1}{|c|}{ Podsústava } & \multicolumn{1}{|c|}{ Provincia } & \multicolumn{1}{|c|}{ Subprovincia } & \multicolumn{1}{c|}{ Oblast' } & \multicolumn{1}{c|}{ Celok } \\
\hline Karpaty & Západné Karpaty & Vonkajšie Západné Karpaty & Východné Beskydy & Čergov \\
Karpaty & Východné Karpaty & Vonkajšie Východné Karpaty & Nízke Beskydy & Ondavská vrchovina \\
Karpaty & Východné Karpaty & Vonkajšie Východné Karpaty & Nízke Beskydy & Beskydské Predhorie \\
Karpaty & Západné Karpaty & Vonkajšie Západné Karpaty & Podhôlno-magurská & Spišsko-šarišské medzihorie \\
Karpaty & Západné Karpaty & Vnútorné Západné Karpaty & Lučenecko-košická zníženina & Košická kotlina \\
\hline
\end{tabular}

Následne preto testujeme mieru rozdielnosti jednotlivých parametrov medzi takto vydelenými zónami. Primárne nám ide o polnohospodárske zázemie, no testujeme aj odlišnosti medzi ostatnými premennými. Rozdiely skúmame analýzou rozptylu (jej neparametrickou alternatívou, kedže vzorky zväčša nemajú normálne rozdelenie, resp. zhodný rozptyl), PCA (váha BPEJ v sídelných areáloch) a zhlukovou analýzou (zonácia náhodných bodov). Analýzy sme realizovali v programe PAST.

Výsledky popísanej analýzy hodnotíme $\mathrm{v}$ kontexte sledovaného priestoru, teda konfrontujeme ich s okolitou krajinou. V hrubých rysoch pritom postupujeme podobne ako T. Lieskovský $(2011,73)$. V skúmanom priestore ju zastupuje 250 GIS-om náhodne vygenerovaných bodov, zhlukovou analýzou rozdelených do viacerých skupín (zón), pre ktoré sme analogicky ku archeologickým komponentom zozbierali obdobné priestorové a environmentálne dáta. Parametre vytriedených zón jednotlivých archeologických sekvencií tak nekomparujeme len medzi sebou, ale porovnávame ich aj s krajinnými pásmami, v ktorých sa podla výsledkov analýzy nachádzajú.

\section{HYDROGEOGRAFICKÁ, GEOMORFOLOGICKÁ A PEDOLOGICKÁ CHARAKTERISTIKA SLEDOVANEJ KRAJINY}

\section{Hydrogeografia}

Rieka Sekčov, významný lavostranný prítok Torysy, preteká krajinou severovýchodného Slovenska príznačnou $30 \%$ lesnatostou. Vyviera v pohorí Čergov na severovýchodnom svahu masívu Bukového vrchu v nadmorskej výške $740 \mathrm{~m}$ a ústi do Torysy v južnej časti Prešova v nadmorskej výške 234 m. Preteká Raslavickou brázdou v Ondavskej vrchovine, Záhradnianskou brázdou v Beskydskom predhorí, výrazným oblúkom obteká masív Kapušianskeho hradného vrchu a smerom na juhozápad tečie mestom Kapušany. Odtial' už zasahuje do severnej časti Košickej kotliny, kde na menšom úseku vymedzuje katastrálnu hranicu obce L'ubotice voči mestu Prešov. V rámci intravilánu mesta sa zregulovaný tok Sekčova vlieva do Torysy. V okolí Prešova pozdĺž Torysy a Sekčova sa riečne terasy vytvorili hlavne po lavej strane doliny. Na ich vývoj silne vplývala kuželová akumulácia potokov stekajúcich zo Slanských vrchov, ktorá nútila Torysu presunút sa smerom na západ (Kolektív 1972, 157). Sekčov od prameňa z lavej strany brehu zavodňujú Tichší potok, Hrabovec, Cakaň, Okružinský potok, Šebastovka, L'ubotický potok, Šalgovícky potok a Solný potok. Z pravej strany brehu sa doň vlievajú potoky Pastovník, Hlboký potok, Laz, Zápotok, Ternianka a Fintický potok. Plocha povodia Sekčova dosahuje 35543 ha. Okrem menovaných prítokov sú súčastou okolitej krajiny aj d’alšie bezmenné potoky.

\section{Geomorfológia}

Krajina, ktorou preteká rieka Sekčov, sa nachádza na rozhraní geomorfologických celkov Vonkajších Západných a Vonkajších Východných Karpát (tabela 3).

K subprovincii Vonkajších Západných Karpát radíme horský masív Čergov a Spišsko-šarišské medzihorie. Čergov je tvorený na flyšovom podklade pieskovcami a ílovcami, v južnej časti bradlovým pásmom. Má hornatinový reliéf pokrytý zmiešanými lesmi, v ktorých prevládajú listnaté stromy ako dub, hrab, buk, jedla, javor a breza. Z ihličnanov sa vyskytuje hlavne smrek. Menšie plochy horského masívu zaberajú lúky a krovinové porasty. Pohorie patrí do mierne teplej a chladnej klimatickej oblasti. Spišsko-šarišské medzihorie je charakterizované ako erózno-tektonická depresia. Jeho geologickú stavbu tvoria prevažne paleogénne horniny vnútrokarpatského flyšu a horniny bradlového pásma. Georeliéf má z väčšej časti stredohorský pahorkatinný charakter s nízkymi plochými chrbtami a širokými úvalinovitými dolinami. Najnižšie časti Spišsko-šarišského medzihoria patria do teplej oblasti, vyššie položené do mierne teplej oblasti a najvyššie časti charakterizujú chladné klimatické podmienky. Značná čast̉ povrchu je odlesnená. 
Ihličnaté a listnaté lesy sa striedajú s plochami oráčin, lúkami a pasienkami.

Súčastou subprovincie Vonkajších Východných Karpát je Ondavská vrchovina a Beskydské predhorie. Ondavská vrchovina je rozsiahle pohorie budované paleogénnymi horninami vonkajšieho flyšu, prevažne ílovcami, pieskovcami, bridlicami a slieňmi. Na reliéfe vrchoviny sa striedajú chrbty s dolinami, kotlinami a brázdami. Povrch pokrývajú striedavo zmiešané lesy, horské lúky, pastviny a polnohospodárska pôda. Z listnatých stromov je najviac zastúpený buk, v menšej miere breza, javor, dub a hrab, z ihličnatých smrek. Prevažná čast’ vrchoviny patrí do mierne teplej klimatickej oblasti. Beskydské predhorie je súčastou flyšového pásma. Na dĺžku meria takmer $100 \mathrm{~km}$ a jeho maximálna šírka nepresahuje $15 \mathrm{~km}$.

Sledované povodie Sekčova preteká aj severnou častou Košickej kotliny, ktorá patrí do subprovincie Vnútorných Západných Karpát. Košická kotlina predstavuje depresiu erózno-tektonického pôvodu. Jej povrch pokrývajú riečne náplavy Hornádu (Košická štrková formácia), Torysy a Olšavy, v ktorých rieky vytvorili široké aluviálne nivy a viaceré riečne terasy. V podloží kvartérnych sedimentov sa nachádzajú morské sedimenty neogénu. Obvod Košickej kotliny lemuje pahorkatinný reliéf. Torysa a Olšava vytvorili vo výplni reliéfu kotliny meandre, čo sa odrazilo v hustom osídlení a aktívnom polnohospodárstve. Z pôvodných dubovo-hrabových a lužných lesov zostali už len nepatrné zvyšky. V severnej časti pri Solivare máme historicky doloženú tažbu soli získavanú varením zo solných prameňov, ktoré tam vyvierali.

\section{Pedologické zloženie}

Sekčov od svojho prameňa pri opustení Čergova cez Ondavskú vrchovinu preteká hornatým územím, pre ktoré sú typické hnedé lesné pôdy nenasýtené, nasýtené, oglejené, miestami zvyškovo karbonátové až pararendziny, ba i hnedé lesné pôdy nenasýtené, nasýtené, oglejené vytvorené na zvetralinách hornín flyšového pásma. Prítomné sú aj illimerizované pôdy oglejené a oglejené pôdy na hlbších zvetralinových pokrovoch. V Beskydskom predhorí v Kapušanoch a okolí sa nachádzajú hnedé lesné pôdy nasýtené a nenasýtené na zvetralinách pevných silikátových hornín a materiály náplavo- vých kuželov. Na úseku medzi Torysou a Slanskými vrchmi je územie tvorené typickými hnedozemami, illimerizovanými pôdami oglejenými až oglejenými pôdami na sprašových a iných hlinách, ako aj na zvetralinách neogénnych hornín. Pozdĺž Torysy prevažujú nivné pôdy. Miestami sú glejové pôdy, a to zväčša na nekarbonátových aluviálnych uloženinách (Kolektív 1972, 384, 385; obr. 2).

\section{CHARAKTERISTIKA KRAJINY V KONTEXTE GIS}

Ťažisko predloženej štúdie spočíva v zhodnotení archeologických dát $\mathrm{v}$ súvislostiach krajiny. Vyššie prezentovaná charakteristika regiónu predstavuje súhrn údajov získaných z tematickej literatúry, ktoré však neumožňujú komparáciu $\mathrm{s}$ dátami excerpovanými z digitálneho výškového modelu a zo sekundárnych informačných vrstiev v prostredí GIS-u. Ako sme uviedli vyššie, na korigovanie tohto nedostatku sme preto $\mathrm{z}$ dotknutého priestoru zozbierali údaje o 250 náhodne vygenerovaných bodoch, ktoré sa týkajú charakteru terénu (nadmorská výška, sklon a drsnost' na mieste a v okruhu 150 a $500 \mathrm{~m}$ ) a pôdneho krytu (okruh $500 \mathrm{~m}$ okolo bodu). V prvom kroku sme zozbierané dáta skúmali analýzou hlavných komponentov. Výsledky ukázali pomerne uniformný ráz krajiny, ked’že sa väčšina bodov zoskupila do nerovnomerného zhluku na negatívnych ramenách osí s tažiskom na prieniku osí, ale s väčším rozptylom najmä na kladnom ramene vodorovnej osi. Zhluk sme v druhom kroku rozložili zhlukovou analýzou. Separovali sme tak tri hlavné klastre, ktoré však možno dalej rozdelit na šest' väčších skupín (K1, K2a, Kb, K3a, K3ba, K3bb). ${ }^{14}$ Tie podla výsledkov PCA na seba plynule nadväzujú a miestami sa prelínajú. S takto vypreparovanými krajinnými zónami v texte d’alej pracujeme. Ich fyzickú charakteristiku uvádzame nižšie.

Zóna K1 predstavuje extrémne krajinné pásmo regiónu ohladom nadmorskej výšky a rázu terénu. Nachádza sa síce v rozpätí nadmorskej výšky 581 až $850 \mathrm{~m}$, avšak prevažne v rozmedzí 651 až $768 \mathrm{~m},{ }^{15}$ povrch má značne svahovitý (od 19 do $25^{\circ}$ ) a vel'mi drsný (drsnost' okolo 10; TRI okolo 3). Zóna leží $\mathrm{v}$ mierne chladnom a mierne vlhkom až v chladnom a vlhkom klimatickom pásme. Ohladom TPK v pôdnom kryte dominujú T2_L (43\%) a T1_L (24\%; teda je v súčasnosti prakticky zalesnená). Ohladom

\footnotetext{
${ }^{14} \mathrm{~V}$ d’alšom texte na označenie zhlukov vyčlenených štatistickou analýzou používame alfanumerické kódy, v ktorých latinské litery označujú druh zhluku (K - krajina, PA - paleolit, NE - neolit, EN - eneolit), arabská číslica ho identifikuje.

${ }^{15}$ Ďalej budeme uvádzat' interval s najväčším výskytom bodov.

${ }^{16} \mathrm{~V}$ zátvorke za kódom BPEJ uvádzame v dalšom texte alfanumerický kód TPK a alfanumerický kód skupiny kvality pôdy 1-9 (teda k1-k9). Klasifikácia vychádza z triedenia BPEJ, v prílohe 9, k vyhláške 508/2004 Z. z. (https://www.zakonypreludi. sk/zz/2004-508\#prilohy [9. 9. 2020]). Najkvalitnejšie pôdy patria do 1. skupiny a najmenej kvalitné do 9. skupiny.
} 
BPEJ má podla PCA najväčšiu váhu BPEJ 0982882, teda kambizeme modálne (T2/k9), 0878265 (T2/k8) a 0978462 (T2/k9), kambizeme modálne alebo rankre. ${ }^{16}$ Zaberá asi $3 \%$ plochy regiónu.

Zóna K2a (450 až 722 m n. m.) je oproti zóne K1 menej svahovitá $\left(13-16^{\circ}\right)$ i drsná (drsnost’ okolo 7; TRI približne 2). Leží v pomerne teplom a suchom, kotlinovitom, až v chladnom a vlhkom klimatickom pásme. Ohladom TPK v pôdnom kryte dominujú T2_L (43\%) a T2 (15\%) s T1 (11 \%). Ohladom BPEJ má podla PCA najväčšiu váhu BPEJ 01081672 (T2/ k9), 0579465 (T2/k8) a 0571215 (O6/k6), kambizeme modálne, rendziny kultizemné a kambizemné a kambizeme kultizemné. Zaberá asi $10 \%$ územia.

Zóna K2b (333 až 464 m n. m.) je menej svahovitá ako zóna K2a $\left(9-14^{\circ}\right)$ i drsná (drsnost’ okolo 5; TRI okolo 1,5). Takto profilované plochy sa nachádzajú aj v pásme K2a, zrejme preto zhluková analýza priradila zóny $\mathrm{k}$ sebe. ${ }^{17}$ Leží $\mathrm{v}$ mierne teplom a mierne vlhkom až pomerne teplom a suchom, kotlinovitom, klimatickom pásme. Ohladom TPK v pôdnom kryte dominujú T2_L (17\%), T2 (16\%), OT3 $(12 \%)$ a T1 (9 \%). Ohladom BPEJ má podla PCA najväčšiu váhu BPEJ 0790462 (T1/k8), 0611002 (O4/k6) a $0769432(\mathrm{O} 7 / \mathrm{k} 7)$ - rendziny kultizemné, fluvizeme kultizemné a kambizeme kultizemné. Zaberá asi $27 \%$ územia.

Zóna K3a (327 až 469 m n. m.) reprezentuje to isté výškové pásmo ako K2b, avšak miernejšie modelované (sklon 5-9 ; drsnost' okolo 2,7; TRI okolo 0,9). Leží v mierne teplom a mierne vlhkom až pomerne teplom a suchom, kotlinovitom, klimatickom pásme. Ohladom TPK v pôdnom kryte dominujú T2 (19\%), O6 (16 \%), OT3 (12\%) a T1 (8 \%). Ohladom BPEJ má podla PCA najväčšiu váhu BPEJ 0871442 (OT3/k7), 0877262 (T2/k8) a 0877562 (T2/k8), kambizeme kultizemné, pseudoglejové a kambizeme kultizemné/rankre kambizemné. Zaberá okolo $21 \%$ územia.

Zóna K3ba (285 až 377 m n. m.) je situovaná nižšie ako K3a a je opät miernejšie modelovaná (sklon 2-5ं; drsnost' okolo 1,8; TRI okolo 0,6). Leží $\mathrm{v}$ mierne teplom a mierne vlhkom až pomerne teplom, suchom kotlinovitom klimatickom pásme. Ohladom TPK v pôdnom kryte dominujú O6 (19\%), OT2 (13 \%), T2 (11 \%) a OT3 (11\%). Ohladom BPEJ má podla PCA najväčšiu váhu BPEJ 0871442 (OT3/ k7), 0877262 (T2/k8) a 0877562 (T2/k8), kambizeme kultizemné, pseudoglejové a kambizeme kultizemné/rankre kambizemné. Zaberá asi $28 \%$ územia.

Zóna K3bb (253 až 292 m n. m.) - ide o dno sekčovského údolia, ktoré predstavuje plochá krajina (sklon 1-3; drsnost' okolo 0,8; TRI okolo 0,3). Leží $\mathrm{v}$ pomerne teplom a mierne suchom až mierne teplom a mierne vlhkom klimatickom pásme. Ohladom TPK v pôdnom kryte dominujú O4 (24\%), O4_L (13\%), O3 (11 \%) a O3_L (9\%). Ohladom BPEJ má podl’a PCA najväčšiu váhu BPEJ 0611002 (O4/k6), 0629005 (O3/k6) a 0550005 (O6/k5), fluvizeme kultizemné glejové, čiernice kultizemné/čiernice kultizemné glejové a hnedozeme kultizemné pseudoglejové. Zaberá iba asi $10 \%$ územia.

Vzhladom na tušené možnosti archaickej agrotechniky budeme za pôdy polnohospodársky exploatovatel'né pravekými populáciami považovat prvé štyri typologicko-produkčne kategórie, z ktorých sa v regióne vyskytujú len kategórie O2, $\mathrm{O} 3$ a O $4 .{ }^{18}$ Ako na stručnej charakteristike krajiny vidiet, väčším podielom týchto kategórií disponuje len najnižšie položená zóna $3 b b$, ktorá by mala zaberat iba desatinu sledovaného územia. Z toho vyplýva, že polnohospodársku exploatáciu skúmaného územia prírodné podmienky značne obmedzovali.

\section{HISTÓRIA A STAV BÁDANIA}

Priekopníkmi organizovaných archeologických prieskumov v centrálnej časti Šariša boli od roku 1945 intelektuálni členovia muzeálneho kuratória Krajského múzea v Prešove, a to $\mathrm{F}$. Blahuta a J. Repčák (Kušnír a i. 2015, 22, 26, 27). Po nástupe V. Budinského-Kričku do Archeologického ústavu SAV, v aktívnej spolupráci s ním, monitorovali povojnovú stavebnú činnost’ v regióne, zaznamenávali stav zachovania archeologických lokalít a na niektorých z nich uskutočnili aj menšie záchranné výskumy. Výsledky ich počiatočného niekol'koročného úsilia súhrnne publikoval F. Blahuta (1960, 95-119) vo Vlastivednej ročenke východného Slovenska v štúdii s názvom „Archeologický profil Šariša", v ktorej na načrtnutých mapových podkladoch orientačne signoval miesta novoobjavených archeologických lokalít a súčasne s nimi zverejnil aj výber chronologicky reprezentatívneho archeologického materiálu.

\footnotetext{
17 To napokon platí pre všetky zóny. Presahy medzi nimi spôsobuje charakter modelácie terénu v okolí bodov.

${ }^{18}$ Samozrejme si pritom uvedomujeme rozdiely v možnostiach napr. neolitických kopaničiarov a germánskych oráčov. Avšak súčasnú využitel'nost̉ menej produkčných pôd podmieňujú okolnosti ako mechanizovaná orba, hnojenie a skladba plodín, ktorými nedisponovali ani protohistorické populácie. K tomu podotkneme, že pokial aj z dnešného pohladu, pri triedení pôd podla kvality na devät skupín, len prvé štyri skupiny „... sú chránené podl’a §12 zákona o ochrane polnohospodárskej pôdy a možno ich dočasne alebo trvale použit’ na nepolnohospodárske účely iba v nevyhnutných prípadoch..." (http://www.podnemapy.sk/ portal/reg_pod_infoservis/kvalita/kvalita.aspx [9.9. 2020]), tak sa v regióne takéto pôdy nevyskytujú, ale evidujeme tu len pôdy od skupiny 5 vyššie a dominujú tu nekvalitné pôdy.
} 
Tabela 4. Korigovanie archeologických lokalít v územno-technických jednotkách.

\begin{tabular}{|c|c|c|c|c|}
\hline $\begin{array}{l}\text { Číslo } \\
\text { lokality }\end{array}$ & $\begin{array}{l}\text { Súčasné označenie } \\
\text { katastra }\end{array}$ & $\begin{array}{l}\text { Pôvodné označenie } \\
\text { katastra }\end{array}$ & Názov polohy & Literatúra \\
\hline 19 & Kapušany & Fintice & Griblovec & $\begin{array}{l}\text { Budinský-Krička 1986, 67; Budin- } \\
\text { ský-Krička 1988; Budinský-Krička/ } \\
\text { Mačala 1990, 42; Luštíková 2018, } 83\end{array}$ \\
\hline 29 & Klušov & Kobyly & Kobyl'ska hora & Budinský-Krička 1964b; 1967, 282 \\
\hline 34 & L'ubotice, čast' Šarišské lúky & Prešov, čast' Šarišské lúky & $\begin{array}{l}\text { Areál závodu na spracovanie } \\
\text { dreva }\end{array}$ & $\begin{array}{l}\text { Budinský-Krička 1979, 54; } \\
\text { Šiška 1976, 83-117 }\end{array}$ \\
\hline 36 & Olšavce/Kochanovce & Tročany & Roveňky & Olexa/Tunia 1996, 135 \\
\hline 45 & Prešov-Solivar & Prešov & $\begin{array}{l}\text { Východne od Sol'nej bane } \\
\text { (južne od kóty } 287,3 \text { a cesty } \\
\text { do Teriakoviec) }\end{array}$ & Budinský-Krička 1979, 54 \\
\hline 54 & Raslavice & Nižné Raslavice & $\begin{array}{l}\text { L'avá strana potoka Brodok } \\
\text { smerom na Tročany }\end{array}$ & Slivka/Mačala 1985, 216 \\
\hline 59 & Tročany & Raslavice & Vrch Prilesok & Budinský-Krička 1957c \\
\hline 61 & Tulčík & Fulianka & $\begin{array}{l}\text { Južný svah kopca Deriky/Drieky } \\
\text { (l'avý breh Ternianky) }\end{array}$ & Budinský-Krička 1956c \\
\hline 65 & Vyšná Šebastová & Sengetov & Košiare/Košariská/Košarisky & Blahuta 1957; 1959, 5 \\
\hline 66 & Vyšná Šebastová & Sengetov & Intravilán (dom 125) & Budinský-Krička 1972b \\
\hline
\end{tabular}

\section{Paleolit}

Od čias prvých prieskumov až do konca druhého desatročia tretieho milénia, vieme v krajine v povodí Sekčova spol’ahlivo označit' len tri paleolitické polohy. Jedna z nich sa nachádza v k. ú. obce Kobyly (lokalita 30) a d’alšie dve sú známe z k. ú. mesta Prešov (lokality 50, 51; tabela 2). Z publikovaných i nepublikovaných správ sme informovaní aj o d’alších minimálne šiestich chotároch s výskytom paleolitických nálezov, no z dostupných opisov nevieme presnejšie lokalizovat' miesta ich primárneho výskytu, Hertník (Bárta 1983, 34), Kapušany, Lubotice, Nemcovce, Podhorany a Záhradné (tabela 4; Blahuta 1960, 96). ${ }^{19}$

Odlišný stav výskumu sledujeme v krajine bezprostredne priliehajúcej k strednému toku Torysy, kde sa $\mathrm{v}$ nedávnej minulosti realizovali viaceré systematicky organizované prieskumy. Severozápadne od Prešova boli vd’aka nim zistené viaceré polohy s výskytom archeologických nálezov, z ktorých pochádzajú ojedinelé artefakty zo stredného paleolitu. Prevažná väčšina z nich vykazuje znaky aurignacienskej kultúry, zaradenej do staršej fázy mladého paleolitu (Kaminská/Moravcová/Šefčáková 2014). Hlavným aktérom prieskumov v oblasti severozápadne od Prešova bol M. Vizdal, ktorý v Šarišskej vrchovine na vyvýšenine Bikoš, zasahujúcej do katastrov Prešova a Vel'kého Šariša, rozpoznal šest' paleolitických staníc (Bánesz/Vizdal 1993, 22, 23; Vizdal 1991, 105, 106). V prieskumnej činnosti pokračoval aj na juhovýchodnom svahu Šarišskej vrchoviny južne od spomínaných sta- novíšt', v priestore Bikoša, kde na Královej hore objavil d’alších osem paleolitických staníc. Na inom mieste $\mathrm{v}$ Prešove, v polohe Vyšné lúky situovanej na pravom brehu Šalgovíckeho potoka, doložil d’alšiu mladopaleolitickú lokalitu (lokalita 51; Vizdal 1992, 102, 103). Pozoruhodnú nálezovú situáciu opísal aj M. Klčo $(1988,75,76)$ v Medzanoch, kde pri t’ažbe hliny v narušenom profile sprašového náveja rozpoznal mladopaleolitické vrstvy so stopami ohnísk. Opakované prieskumy v Medzanoch, koordinované M. Vizdalom, potvrdili výskyt paleolitických nálezov aj v iných polohách (Derfiňák/Karabinoš/ Vizdal 2009a, 59-61; Karabinoš/Volanská 2015, 126). Menované lokality spolu s ostatnými (Derfiňák/Karabinoš/Vizdal 2009b, 61, 62; Tunia 2008; Tunia/Mačala 1997; 176; Valde-Nowak 2008) vierohodne vypovedajú o výraznejšom zásahu skupín paleolitického obyvatel'stva do severnejších regiónov východného Slovenska, ako bolo doposial' zjavné.

\section{Neolit}

Z celkového počtu 22 archeologických lokalít, chronologicky zaradených do obdobia neolitu, boli na 10 z nich uskutočnené záchranné alebo menšie zistovacie výskumy. Tie preukázali príslušnost’ nálezového materiálu ku kultúre s východnou lineárnou keramikou a $\mathrm{k}$ bukovohorskej kultúre. Prvé neolitické nálezy objavil J. Repčák vo Finticiach počas prieskumu výšinnej polohy Várhegy v roku 1950 (lokalita 3; Budinský-Krička 1950). F. Blahuta

\footnotetext{
${ }^{19} \mathrm{Z}$ tohto dôvodu neboli zahrnuté do databázy lokalít analyzovaných v prostredí GIS.
} 
sa v roku 1956 zaslúžil o preskúmanie neolitického sídliskového objektu v Kapušanoch, ktorý sa o desatročie neskôr stal základným prameňom pre vyčlenenie skupiny Tiszadob na Slovensku (lokalita 26; Blahuta 1959, 5-32; Šiška 1993, 37-40). V koordinácii s výstavbou hospodárskych objektov bývalého JRD boli na menovanej lokalite $\mathrm{v}$ druhej polovici 50. rokov uskutočnené viaceré sondážne výkopy. V rovnakom období F. Blahuta monitoroval aj podmývaný strmý breh Sekčova vo Fulianke, kde na dlhšom úseku zdokumentoval profil s výraznou sídliskovou vrstvou bukovohorskej kultúry (lokalita 10; Blahuta 1957a; 1959, 5). V ned’alekej Vyšnej Šebastovej, na výšinnej polohe Košiare, taktiež preskúmal výrazne porušenú sídliskovú jamu (lokalita 65; Blahuta 1957b; 1959, 5). V druhej polovici 20. storočia sa v mikroregióne Sekčova uskutočnil iba jeden záchranný výskum na ploche „väčšieho" rozsahu, počas ktorého boli objavené aj nálezy z čias najstarších rolníckych kultúr. Ide o polohu Šarišské lúky v L’uboticiach, ktorá sa nachádza na jednom z výbežkov nízkej lavostrannej terasy Sekčova a z dvoch strán je obklopená močaristými lúkami (lokalita 34). Na začiatku roku 1973 ju ako polykultúrnu archeologickú lokalitu objavili pracovníci Múzea Slovenskej republiky rád v Prešove spolu s A. Točíkom. Skúmaný areál bol z dvoch tretín zničený už pred začatím archeologického výskumu. Ostatná pomerne zachovaná čast plochy bola preskúmaná pomocou 13 overovacích sond. Výsledky výskumu naznačili, že uvedené miesto bolo najintenzívnejšie obývané v mladšej dobe bronzovej osadenstvom gávskej kultúry. Avšak objavili sa aj nálezy, vrátane sídliskových objektov, súvisiace s eneolitickým osídlením polohy ludom lažnianskej skupiny a badenskej kultúry. Neolitické nálezy kultúry s východnou lineárnou keramikou boli objavené $\mathrm{v}$ dvoch sondách a $\mathrm{v}$ jednom rozlahlom sídliskovom objekte. Stopy osídlenia bukovohorskej kultúry sa nápadne koncentrovali len na južnom a západnom úpätí výbežku riečnej terasy (Šiška 1976, 83, 84, 86, 90, 92, 96).

Na základe partnerskej spolupráce Katedry všeobecných dejín Filozofickej fakulty Prešovskej univerzity v Prešove s Archeologickým inštitútom Jagelovskej univerzity v Krakove a pod záštitou Archeologického ústavu SAV v Nitre bol v roku 2001 vo Finticiach, v polohách označených ako Košariská I a Košariská II, realizovaný výskum na vedecké účely. Jeho primárnym cielom bolo detailnejšie preskúmat miesto a okolie porušeného sídliskového objektu zo záveru staršieho neolitu, ktorý zazna- menal M. Vizdal $(2000,153)$ ešte počas prieskumu v roku 1998 (lokalita 8). V polohe Košariská I sa teda uskutočnil výkop s rozmermi $10 \times 9 \mathrm{~m}$ a vedla neho bola vyhíbená sonda s rozmermi 1,5-3,5 m. Stratigrafická situácia v sídliskovej jame ukázala výskyt vel'kých kusov prevažne plochých kameňov poukladaných jeden vedla druhého, ktoré mohli byt̉ výsledkom zámernej antropogénnej činnosti. Približne $400 \mathrm{~m}$ západne od skúmaného objektu skupiny Tiszadob, v polohe Košariská II (lokalita 9), boli vyhĺbené dalšie tri overovacie sondy s rozmermi $3 \times 2 \mathrm{~m}$. V jednej z nich sa v nepravidelných zoskupeniach koncentrovali zvieracie a ludské kosti spolu s vel'kým počtom kameňov (Nowak/Vizdal 2002, 144, 145). Ďalšie informácie o osídlení chotára Fintíc v mladšej dobe kamennej priniesli výsledky novodobých záchranných výskumov Archeologickej spoločnosti Triglav s. r. o. V roku 2016 v časti Fisky-Tormáš, v polohe Martinec, preskúmal K. Švaňa časti dvoch rozmernejších objektov bukovohorskej kultúry (lokalita 5; Simčík/Švaňa 2016). Nečakaný objav priniesol aj výskum na stavbe „Komlexnej rekonštrukcie severného krídla sýpky kaštiela vo Finticiach", počas ktorého bol v južnej časti sýpky v stavebnom výkope pre kanalizáciu zdokumentovaný jeden objekt bukovohorskej kultúry (lokalita 6; Šimčík 2015a).

\section{Eneolit}

V okolí Sekčova a jeho prítokov sa doposial' nezaznamenali pamiatky z obdobia staršieho eneolitu. Nám známe nálezy súvisia len s o čosi mladším eneolitickým osídlením reprezentovaným ludom lažnianskej skupiny, badenskej kultúry a skupiny východoslovenských mohýl kultúry so šnúrovou keramikou. V literatúre sa uvádza aj ojedinelá správa o nálezoch kultúry Nyírség-Zatín z Kapušian, z polohy Griblovec (lokalita 19; Budinský-Krička 1986, 67).

$\mathrm{Z}$ celkového počtu 28 lokalít vieme $\mathrm{v}$ teréne identifikovat' len $18 \mathrm{z}$ nich. Informácie týkajúce sa ostatných 11 lokalít, s nejasne určenými alebo vôbec neuvedenými polohami, neboli pre potreby našej štúdie zohladnené. ${ }^{20}$ Pri rekapitulácii doterajších výsledkov bádania s ohladom na výskum eneolitických kultúr za najviac prínosné považujeme výsledky záchranných výskumov v spomínaných Luboticiach, čast Šarišské lúky (lokalita 34), vo Finticiach na lokalite Fisky-Tormáš, v polohe Martinec (lokalita 5), v Prešove-Solivare, v polohe Za cintorí-

\footnotetext{
${ }^{20}$ Kapušany (Blahuta 1960, 104), Klušov (Budinský-Krička 1979, 50; 1991, 100), Kobyly (Budinský-Krička 1991, 100), Nemcovce (Krička 1941); Prešov, čast' Solivar (Budinský-Krička 1960e), Prešov, časť Šalgovík (Budinský-Krička 1960f), Nižná Šebastová (Blahuta 1960, 104), Proč (Tomášová 1998, 158), Vyšná Šebastová (Blahuta 1960, 104).
} 
nom (lokalita 49) a v Prešove-Šalgovíku, v polohe Za kostolom (lokalita 52).

V Luboticiach v časti Šarišské lúky bola rozpoznaná kultúrna vrstva so štyrmi objektmi lažnianskej skupiny (Šiška 1976, 92, 93). Mladšie obdobie eneolitu na menovanej lokalite zastupuje nálezový materiál badenskej kultúry. Hoci z tohto časového horizontu bol zdokumentovaný iba jeden sídliskový objekt, zachované artefakty badenskej kultúry pochádzajúce zo sondážnych výkopov naznačili, že v období stredného eneolitu mohla byt’ obývaná podstatná čast' evidovaného náleziska (Šiška 1976, 96). Donedávna neznámy najstarší horizont osídlenia badenskej kultúry na území východného Slovenska sa podarilo rozpoznat aj vd’aka nálezovým celkom z výskumu v Prešove-Solivare, v polohe Za cintorínom. ${ }^{21}$ Po odbornom vyhodnotení bude zrejme možné do rovnakého časového horizontu zaradit aj d’alší nálezový celok z lokality Fisky-Tormáš, z obce Fintice (Šimčík/Švaňa/Hupč́k 2014) ${ }^{22}$. Iný sídliskový objekt badenskej kultúry bol preskúmaný aj v Prešove, v časti Šalgovík, v polohe Za kostolom, ktorú vzhl'adom na jej nadmorskú výšku 319-324 m radíme k výšinným lokalitám so strategickým potenciálom vzhladom na okolie (Kotorová-Jenčová 2017, 97, 98). Miesta spájané s migráciou cudzích pastierskych skupín ludu východoslovenských mohýl kultúry so šnúrovou keramikou v sledovanej oblasti ako prvý rozpoznal V. Budinský-Krička (1959; 1961; 1964b; 1967, 282; 1972c; 1979, 50; 1991, 100). V Ondavskej vrchovine, v oblasti tzv. Kurimskej brázdy, sa v roku 1995 uskutočnil aj revidovaný prieskum v chotári obce Klušov, počas ktorého bolo obhliadnuté mohylové pohrebisko tohto ludu s 33 identifikovanými mohylami navrśšenými na vrchu Kobylej hory (Tunia/Mačala 1997, 176).

\section{MODELY OSÍDLENIA}

\section{Paleolit}

Malý počet presne lokalizovaných paleolitických nálezísk (lokality 30, 50, 51) neumožňuje ich podrobnejšie triedenie. Problém uvedeného súboru spočiva aj v tom, že ani jednu zo zmienených lokalít nie je možné spojit s konkrétnou archeologickou kultúrou, teda posudzovat ich rovnocenne v extrémne širokom časovom spektre paleolitu je skôr otázne. Pri priemete na mapu vidiet', že dve z nich sa nachádzajú asi 2,6 km od seba v južnej časti sekčovskej doliny v Košickej kotline. Tretia je situovaná mimo nich, a to v Ondavskej vrchovine na terasovitom výbežku nad sútokom Hrabovca a Brôdku. Súhrnnú štatistiku vybratých premenných sekundárnej informačnej vrstvy „Priestorové dáta“ zobrazuje tabela 5.

Vzhladom na predpokladanú ekonomickú stratégiu paleolitických loveckých a zberačských skupín $\mathrm{v}$ tejto kapitole upúštame od posudzovania osídlenia vo vztahu $\mathrm{k}$ pôdnej skladbe regiónu, úrodnost pôd v kontexte takéhoto „hospodárstva“ prakticky nemá výpovednú hodnotu. Typ pôd síce môže do určitej miery svedčit o charaktere pôvodného porastu, ten sa však vzhladom na dĺžku a zmeny klímy pleistocénu určite viackrát vystriedal. Na zistenie charakteru konkrétnej fauny spojenej s evidovanými lokalitami potrebujeme vzorky, ktoré by sa mohli získat len medziodborovo zameraným terénnym výskumom. Preto sa stručne zmienime iba o výsledkoch porovnávacej analýzy v rámci informačnej vrstvy „Priestorové dáta“.

Podla nich paleolitické lokality v povodí Sekčova okupujú krajinné pásmo K3ba $(\mathrm{p}=0,08243)$ a K3bb $(p=0,5427)$, nachádzajú sa teda priamo na údolnom dne, alebo na najnižších riečnych terasách. Štatisticky významné rozdiely ohladom jednotlivých premenných sa zistili skôr pri pásme K3bb (parametre ",Sklon_150 m“, ,Drsnost'_150 m“, „Drsnost'_500 m“, „TRI_150 m“), takže sa zdá, že v tomto pásme by sa mohli osídlovat’ o niečo sklonenejšie a drsnejšie plochy, než aké v nive prevládajú. Obývané areály sa nachádzali blízko vody a orientované boli viac-menej na juhozápad až západ. Vzhladom na to, že prevýšenie nad okolím nedosahuje vysoké hodnoty, zrejme nešlo o lovecké stanice, odkial' by sa pozorovali pohyby stád lovnej zveri (tabela 5). Bez d’alšieho výskumu je však sídlisková problematika paleolitu na Sekčove neriešitelná.

\section{Neolit}

Lineárna regresia premenných „Nadmorská výška“ a "Vzdialenoste ku komunikačnému koridoru" ukazuje rozptyl neolitického osídlenia do viacerých krajinných pásiem. Najzovretejší zhluk lokalít evidujeme $\mathrm{v}$ zóne NE1. Pomerne zovreté sú zóny NE3 a NE4, naopak zóna NE2 vykazuje väčśí rozptyl (obr. 6: 1). Úplne excentricky je lokalizovaný jeden komponent (lokalita 1, Bartošovce-Záhumnie). Pri priemete na mapu vidiet', že zóna NE1 reprezentuje osídlenie údolia Sekčova, zóna NE2 viaceré bočné údolia zväčša na prítokoch Ladianky (Kapušiansky a Porubský potok) a jednu lokalitu z pravobrežia Sekčova v povodí Fintického potoka. Nad ňou sú situované komponenty

\footnotetext{
${ }^{21}$ Výskum spoločnosti Archeologická agentúra, s. r. o. v roku 2014. Nepublikované.

22 Výskum Archeologickej spoločnosti Triglav, s. r. o. v roku 2014.
} 
Tabela 6. Neolitické osídlenie, súhrnná štatistika premenných zo sekundárnej informačnej vrstvy „Priestorové dáta“.

\begin{tabular}{|c|c|c|c|c|c|c|c|}
\hline & $N$ & Min & Max & 25 percentil & 75 percentil & Priemer & Medián \\
\hline Nadmorská výška_NE1 & 7 & 244,45 & 271,60 & 250,45 & 270,00 & 258,88 & 259,81 \\
\hline Nadmorská výška_NE2 & 5 & 279,73 & 312,13 & 283,73 & 309,99 & 295,10 & 288,06 \\
\hline Nadmorská výška_NE3 & 4 & 378,68 & 472,90 & 381,55 & 462,04 & 417,79 & 409,79 \\
\hline Nadmorská výška_NE4 & 4 & 363,85 & 423,64 & 364,30 & 409,40 & 379,95 & 366,16 \\
\hline Nadmorská výška_NE5 & 1 & 370,00 & 370,00 & 370,00 & 370,00 & 370,00 & 370,00 \\
\hline Vzdialenost'_koridor_NE1 & 7 & 0 & 722 & 0 & 242 & 184 & 125 \\
\hline Vzdialenost'_koridor_NE2 & 5 & 1653 & 5151 & 2183 & 4495 & 3215 & 2720 \\
\hline Vzdialenost'_koridor_NE3 & 4 & 1035 & 2551 & 1393 & 2546 & 2146 & 2498 \\
\hline Vzdialenost'_koridor_NE4 & 4 & 6864 & 10659 & 7127 & 10072 & 8437 & 8112 \\
\hline Vzdialenost'_koridor_NE5 & 1 & 17120 & 17120 & 17120 & 17120 & 17120 & 17120 \\
\hline Vzdialenost'_tok_NE1 & 7 & 4 & 328 & 38 & 112 & 102 & 90 \\
\hline Vzdialenost'_tok_NE2 & 5 & 14 & 248 & 26 & 191 & 101 & 72 \\
\hline Vzdialenost'_tok_NE3 & 4 & 492 & 889 & 545 & 858 & 713 & 735 \\
\hline Vzdialenost'_tok_NE4 & 4 & 135 & 669 & 148 & 599 & 345 & 288 \\
\hline Vzdialenost'_tok_NE5 & 1 & 265 & 265 & 265 & 265 & 265 & 265 \\
\hline Prevýšenie_150m_NE1 & 7 & 1 & 7 & 3 & 7 & 4 & 4 \\
\hline Prevýšenie_150m_NE2 & 5 & 7 & 14 & 8 & 12 & 10 & 9 \\
\hline Prevýšenie_150m_NE3 & 4 & 32 & 53 & 34 & 52 & 43 & 44 \\
\hline Prevýšenie_150m_NE4 & 4 & 13 & 18 & 13 & 18 & 16 & 16 \\
\hline Prevýšenie_150m_NE5 & 1 & 7 & 7 & 7 & 7 & 7 & 7 \\
\hline Prevýšenie_500m_NE1 & 7 & 1 & 14 & 3 & 10 & 7 & 7 \\
\hline Prevýšenie_500m_NE2 & 5 & 10 & 27 & 10 & 23 & 17 & 19 \\
\hline Prevýšenie_500m_NE3 & 4 & 78 & 142 & 81 & 131 & 102 & 93 \\
\hline Prevýšenie_500m_NE4 & 4 & 25 & 47 & 26 & 43 & 33 & 31 \\
\hline Prevýšenie_500m_NE5 & 1 & 16 & 16 & 16 & 16 & 16 & 16 \\
\hline Sklon_NE1 & 7 & 1 & 5 & 2 & 5 & 3 & 3 \\
\hline Sklon_NE2 & 5 & 4 & 15 & 4 & 11 & 8 & 6 \\
\hline Sklon_NE3 & 4 & 9 & 18 & 10 & 17 & 13 & 13 \\
\hline Sklon_NE4 & 4 & 4 & 10 & 4 & 9 & 7 & 6 \\
\hline Sklon_NE5 & 1 & 2 & 2 & 2 & 2 & 2 & 2 \\
\hline Sklon_150m_NE1 & 7 & 1 & 6 & 3 & 5 & 4 & 3 \\
\hline Sklon_150m_NE2 & 5 & 5 & 8 & 5 & 7 & 6 & 5 \\
\hline Sklon_150m_NE3 & 4 & 12 & 16 & 13 & 16 & 15 & 15 \\
\hline Sklon_150m_NE4 & 4 & 5 & 11 & 5 & 10 & 8 & 7 \\
\hline Sklon_150m_NE5 & 1 & 3 & 3 & 3 & 3 & 3 & 3 \\
\hline Sklon_500m_NE1 & 7 & 1 & 5 & 3 & 5 & 4 & 4 \\
\hline Sklon_500m_NE2 & 5 & 5 & 7 & 5 & 7 & 6 & 6 \\
\hline Sklon_500m_NE3 & 4 & 13 & 17 & 13 & 16 & 14 & 14 \\
\hline Sklon_500m_NE4 & 4 & 6 & 10 & 6 & 10 & 9 & 9 \\
\hline Sklon_500m_NE5 & 1 & 5 & 5 & 5 & 5 & 5 & 5 \\
\hline Drsnost'_NE1 & 7 & 0 & 3 & 1 & 2 & 2 & 2 \\
\hline Drsnost'_NE2 & 5 & 2 & 6 & 2 & 5 & 3 & 3 \\
\hline Drsnost'_NE3 & 4 & 4 & 8 & 5 & 7 & 6 & 6 \\
\hline Drsnost'_NE4 & 4 & 2 & 4 & 2 & 4 & 3 & 3 \\
\hline Drsnost'_NE5 & 1 & 1 & 1 & 1 & 1 & 1 & 1 \\
\hline Drsnost'_150m_NE1 & 7 & 0 & 3 & 1 & 2 & 2 & 2 \\
\hline Drsnost'_150m_NE2 & 5 & 2 & 3 & 2 & 3 & 2 & 2 \\
\hline Drsnost'_150m_NE3 & 4 & 5 & 7 & 6 & 7 & 7 & 7 \\
\hline
\end{tabular}


Tabela 6. Pokračovanie.

\begin{tabular}{|l|c|c|c|c|c|c|c|}
\cline { 2 - 7 } \multicolumn{1}{c|}{} & N & Min & Max & 25 percentil & 75 percentil & Priemer & Medián \\
\hline Drsnost'_150m_NE4 & 4 & 2 & 5 & 2 & 4 & 3 & 3 \\
Drsnost'_150m_NE5 & 1 & 1 & 1 & 1 & 1 & 1 & 1 \\
Drsnost'_500m_NE1 & 7 & 1 & 2 & 1 & 2 & 2 & 2 \\
Drsnost'_500m_NE2 & 5 & 2 & 3 & 2 & 3 & 3 & 3 \\
Drsnost'_500m_NE3 & 4 & 6 & 7 & 6 & 7 & 6 & 6 \\
Drsnost'_500m_NE4 & 4 & 3 & 5 & 3 & 5 & 4 & 4 \\
Drsnost'_500m_NE5 & 1 & 2 & 2 & 2 & 2 & 2 & 2 \\
Orientácia_NE1 & 7 & 79 & 288 & 89 & 273 & 188 & 197 \\
Orientácia_NE2 & 5 & 53 & 173 & 65 & 158 & 105 & 78 \\
Orientácia_NE3 & 4 & 152 & 290 & 153 & 270 & 202 & 183 \\
Orientácia_NE4 & 4 & 13 & 244 & 35 & 215 & 122 & 115 \\
Orientácia_NE5 & 1 & 87 & 87 & 87 & 87 & 87 & 87 \\
Orientácia_150m_NE1 & 7 & 130 & 292 & 162 & 286 & 215 & 193 \\
Orientácia_150m_NE2 & 5 & 129 & 171 & 130 & 162 & 147 & 152 \\
Orientácia_150m_NE3 & 4 & 138 & 234 & 141 & 222 & 177 & 169 \\
Orientácia_150m_NE4 & 4 & 31 & 238 & 48 & 207 & 121 & 108 \\
Orientácia_150m_NE5 & 1 & 95 & 95 & 95 & 95 & 95 & 95 \\
\hline
\end{tabular}

zóny NE3, ku ktorej patria aj dve výšinné polohy (obr. 6: 2). Zóna NE4 predstavuje odlahlé lokality zasunuté hlboko do potočných údolí alebo na ich záver (Dlhý potok, Ternianka). Súhrnnú štatistiku vybratých premenných sekundárnej informačnej vrstvy „Priestorové dáta“ a „Environmentálne dáta" zobrazujú tabely 6-11.

Pred porovnaním vyčlenených zón medzi sebou sa konfrontovali s krajinou a jej členením. V rozložení podla výškových pásiem krajiny tak zóna NE1 zodpovedá krajinnému pásmu K3bb $(\mathrm{p}=0,1792)$, zóna NE2 skôr pásmu K3ba $(\mathrm{p}=0,1843)$ než pásmu K3bb ( $\mathrm{p}=0,06389)$, zóna NE3 pásmam K2b a K3a ( $\mathrm{p}=0,5971$ a 0,5996), zóna NE4 opät skôr pásmam K2b a K3a ( $p=0,74$ a p =0,69), ale vzhladom na jej vel'ký geografický rozptyl zasahuje aj do zóny K3ba $(\mathrm{p}=0,2009)$. Ďalej budeme komparovat' dáta zón neolitického osídlenia s konkrétnym krajinným kontextom. Výsledky možno zhrnút nasledovne.

Polohy zóny NE1 (lokality 6, 10, 20, 26, 34, 44, 50) vykazujú ohladom sklonu voči krajinnému kontextu (K3bb) štatisticky významný rozdiel na mieste nálezu a v širšom okolí. Neolitické skupiny sa usadzovali v teréne o niečo svažitejšom ako mal tento typ terénu (ale prevyšujú ho iba asi o 1 až $2^{\circ}$ ), rovnakú tendenciu badat' aj pri parametroch „Drs-

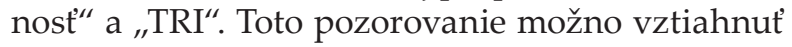
k parametru „Prevýšenie nad okolím“ (dosahovalo prinajmenšom $3 \mathrm{~m}$ ) a vyvodit $\mathrm{z}$ toho, že sa v nive osídlovali vyvýšenejšie a chránenejšie miesta, to je napokon vzhl'adom na kontext (záplavové územie) logické. Vyberali sa pritom miesta skôr orientované na juh v blízkosti vodného zdroja (tabela 6).
Ohladom pôdneho krytu sa medzi skladbou pôd v zázemí archeologických komponentov zóny NE1 a daného krajinného kontextu (K3bb) štatisticky významné rozdiely nezistili (s výnimkou TPK O5_L a OT3_L, ktoré sa v sídelnom areáli lokalít nevyskytli). Ako vidiet v tabele 7, najväčší percentuálny podiel v pôdach majú TPK O5 (20\%), O4_L (19\%) a O4 (19\%), teda v miestnom kontexte najúrodnejšie typy pôd, avšak z hladiska triedenia podla kvality ide iba o pôdy menej kvalitné (tabela 7; 8).

Polohy zóny NE2 (lokality 5, 31, 32, 35, 65) sa nachádzajú v bočných údoliach. Opät možno konštatovat', že osídlené plochy sa parametrami odlišujú od charakteru okupovaných krajinných pásiem (K3ba, K3bb), pričom majú bližšie k pásmu K3ba. Komponenty sa nachádzajú na svahoch, ktoré majú $\mathrm{v}$ priemere väčší sklon ako je priemer i medián okolia, a to isté platí aj pre premenné „Drsnost" a "TRI". Pomerne vysoké ćíslo dosahuje aj prevýšenie nad okolím (minimálne $7 \mathrm{~m}$, ale v sídelnom areáli od 10 do $27 \mathrm{~m}$ ). Orientované boli viac-menej na juh a situované boli v blízkosti vodného toku (tabela 6). Z uvedeného vyplýva, že aj v tomto prípade možno vysledovat zámerný výber miesta pre osídlenie.

Ohladom pôdneho krytu sa v skladbe pôd v zázemí archeologických komponentov zóny NE2 a daného krajinného kontextu (K3ba a K3bb) zistili rozdiely. Z orných pôd chýbajú kategórie O2, O3, ktoré v dotknutých krajinných pásmach evidujeme. V zázemí lokalít tak registrujeme až TPK O4, O5 a O6, v poslednom prípade sa však zóna NE2 a K3ba štatisticky líšia (to napokon platí aj pre TPK O7). Ako vidiet' v tabele 7, práve TPK O6 má v priemere 
Tabela 7. Neolitické osídlenie, súhrnná štatistika premenných zo sekundárnej informačnej vrstvy „Environmentálne dáta. Percentuálne zastúpenie typologicko-produkčných kategórií (TPK) v sídelnom areáli“.

\begin{tabular}{|c|c|c|c|c|c|c|c|}
\hline & $\mathrm{N}$ & Min & Max & 25 percentil & 75 percentil & Priemer & Medián \\
\hline O2_\%_NE1 & 7 & 0 & 4 & 0,00 & 0,00 & 0,57 & 0,00 \\
\hline O3_\%_NE1 & 7 & 0 & 5 & 0,00 & 0,00 & 0,71 & 0,00 \\
\hline O3_L_\%_NE1 & 7 & 0 & 15 & 0,00 & 0,00 & 2,14 & 0,00 \\
\hline O4_\%_NE1 & 7 & 0 & 57 & 1,00 & 40,00 & 18,57 & 10,00 \\
\hline O4_\%_NE2 & 5 & 0 & 9 & 0,00 & 4,50 & 1,80 & 0,00 \\
\hline O4_L_\%_NE1 & 7 & 0 & 70 & 0,00 & 64,00 & 19,14 & 0,00 \\
\hline O5_\%_NE1 & 7 & 0 & 72 & 5,00 & 29,00 & 19,86 & 12,00 \\
\hline O5_\%_NE2 & 5 & 0 & 52 & 0,00 & 32,00 & 12,80 & 0,00 \\
\hline O5_\%_NE3 & 4 & 0 & 13 & 0,50 & 10,25 & 4,25 & 2,00 \\
\hline O5_\%_NE5 & 1 & 52 & 52 & 52,00 & 52,00 & 52,00 & 52,00 \\
\hline O5_L_\%_NE3 & 4 & 0 & 2 & 0,00 & 1,50 & 0,50 & 0,00 \\
\hline O6_\%_NE1 & 7 & 0 & 59 & 0,00 & 47,00 & 17,29 & 2,00 \\
\hline O6_\%_NE2 & 5 & 0 & 84 & 28,50 & 77,00 & 54,00 & 59,00 \\
\hline O6_\%_NE3 & 4 & 0 & 1 & 0,00 & 0,75 & 0,25 & 0,00 \\
\hline O6_\%_NE4 & 4 & 0 & 15 & 0,00 & 11,25 & 3,75 & 0,00 \\
\hline O6_L_\%_NE1 & 7 & 0 & 18 & 0,00 & 0,00 & 2,57 & 0,00 \\
\hline O6_L_\%_NE3 & 4 & 0 & 2 & 0,00 & 2,00 & 1,00 & 1,00 \\
\hline O6_L_\%_NE4 & 4 & 0 & 75 & 0,00 & 57,00 & 19,50 & 1,50 \\
\hline O7_\%_NE1 & 7 & 0 & 28 & 0,00 & 11,00 & 7,00 & 0,00 \\
\hline O7_\%_NE2 & 5 & 0 & 11 & 0,00 & 10,00 & 5,60 & 8,00 \\
\hline O7_\%_NE3 & 4 & 0 & 8 & 0,00 & 7,00 & 3,00 & 2,00 \\
\hline O7_\%_NE4 & 4 & 0 & 99 & 0,00 & 74,50 & 25,00 & 0,50 \\
\hline O7_L_\%_NE1 & 7 & 0 & 1 & 0,00 & 0,00 & 0,14 & 0,00 \\
\hline O7_L_\%_NE2 & 5 & 0 & 1 & 0,00 & 0,50 & 0,20 & 0,00 \\
\hline O7_L_\%_NE3 & 4 & 0 & 10 & 0,25 & 9,25 & 4,50 & 4,00 \\
\hline O7_L_\%_NE4 & 4 & 0 & 12 & 0,00 & 9,50 & 3,50 & 1,00 \\
\hline OT2_\%_NE1 & 7 & 0 & 2 & 0,00 & 0,00 & 0,29 & 0,00 \\
\hline OT2_\%_NE2 & 5 & 0 & 17 & 0,00 & 12,50 & 5,00 & 0,00 \\
\hline OT2_\%_NE3 & 4 & 0 & 10 & 0,00 & 7,50 & 2,50 & 0,00 \\
\hline OT2_\%_NE4 & 4 & 0 & 24 & 0,00 & 18,00 & 6,00 & 0,00 \\
\hline OT2_L_\%_NE1 & 7 & 0 & 8 & 0,00 & 0,00 & 1,14 & 0,00 \\
\hline OT3_\%_NE2 & 5 & 0 & 38 & 0,50 & 28,50 & 13,60 & 10,00 \\
\hline OT3_\%_NE3 & 4 & 0 & 22 & 4,50 & 22,00 & 15,50 & 20,00 \\
\hline OT3_\%_NE4 & 4 & 0 & 26 & 0,00 & 24,75 & 11,75 & 10,50 \\
\hline OT3_\%_NE5 & 1 & 38 & 38 & 38,00 & 38,00 & 38,00 & 38,00 \\
\hline OT3_L_\%_NE1 & 7 & 0 & 1 & 0,00 & 0,00 & 0,14 & 0,00 \\
\hline OT3_L_\%_NE3 & 4 & 3 & 22 & 4,75 & 20,25 & 12,50 & 12,50 \\
\hline OT3_L_\%_NE4 & 4 & 0 & 8 & 0,00 & 6,50 & 2,50 & 1,00 \\
\hline T1_\%_NE1 & 7 & 0 & 31 & 0,00 & 16,00 & 7,43 & 0,00 \\
\hline T1_\%_NE2 & 5 & 0 & 7 & 0,00 & 3,50 & 1,40 & 0,00 \\
\hline T1_\%_NE3 & 4 & 0 & 2 & 0,00 & 1,75 & 0,75 & 0,50 \\
\hline T1_\%_NE4 & 4 & 0 & 8 & 0,00 & 6,25 & 2,25 & 0,50 \\
\hline T1_L_\%_NE1 & 7 & 0 & 3 & 0,00 & 0,00 & 0,43 & 0,00 \\
\hline T1_L_\%_NE2 & 5 & 0 & 2 & 0,00 & 1,00 & 0,40 & 0,00 \\
\hline T1_L_\%_NE3 & 4 & 0 & 41 & 0,75 & 34,00 & 14,25 & 8,00 \\
\hline T1_L_\%_NE4 & 4 & 0 & 20 & 0,00 & 16,25 & 6,25 & 2,50 \\
\hline
\end{tabular}


Tabela 7. Pokračovanie.

\begin{tabular}{|l|c|c|c|c|c|c|c|}
\cline { 2 - 7 } \multicolumn{1}{c|}{} & N & Min & Max & 25 percentil & 75 percentil & Priemer & Medián \\
\hline T2_\%_NE1 & 7 & 0 & 8 & 0,00 & 4,00 & 2,00 & 0,00 \\
T2_\%_NE2 & 5 & 0 & 11 & 0,00 & 9,50 & 5,20 & 7,00 \\
T2_\%_NE3 & 4 & 0 & 50 & 0,50 & 40,00 & 15,50 & 6,00 \\
T2_\%_NE4 & 4 & 0 & 57 & 0,75 & 45,00 & 17,25 & 6,00 \\
T2_\%_NE5 & 1 & 11 & 11 & 11,00 & 11,00 & 11,00 & 11,00 \\
T2_L_\%_NE1 & 7 & 0 & 3 & 0,00 & 0,00 & 0,43 & 0,00 \\
T2_L_\%_NE3 & 4 & 0 & 56 & 4,00 & 49,50 & 25,50 & 23,00 \\
\hline T2_L_\%_NE4 & 4 & 0 & 7 & 0,00 & 5,75 & 2,25 & 1,00 \\
\hline
\end{tabular}

Tabela 8. Neolitické osídlenie. Pät bonít pôdno-ekologických jednotiek (BPEJ) s najsilnejším kladným skóre podl’a výsledkov analýz hlavných komponentov (PCA) v zóne NE1.

\begin{tabular}{|c|c|c|c|c|c|}
\hline BPEJ & Pôdny typ & Body & TPK & Kvalita & PC 1 \\
\hline 0529505 & $\begin{array}{l}\text { čiernice kultizemné až kultizemné, glejové, zo sprašových a svahových hlín, } \\
\text { stredne t’ažké až t'ažké }\end{array}$ & 70 & $\mathrm{O} 4$ & 6 & 0,667050 \\
\hline 0529403 & $\begin{array}{l}\text { čiernice kultizemné až kultizemné, glejové, zo sprašových a svahových hlín, } \\
\text { stredne t’ažké až t’ažké }\end{array}$ & 74 & $\mathrm{O} 3$ & 6 & 0,142940 \\
\hline 0511005 & fluvizeme kultizemné glejové, stredne t'ažké, lokálne t’ažké & 64 & O5 & 5 & 0,047647 \\
\hline 0529202 & $\begin{array}{l}\text { čiernice kultizemné až kultizemné, glejové, zo sprašových a svahových hlín, } \\
\text { stredne t'ažké až t'ažké }\end{array}$ & 80 & $\mathrm{O} 3$ & 6 & 0,047647 \\
\hline 0529002 & $\begin{array}{l}\text { čiernice kultizemné až kultizemné, glejové, zo sprašových a svahových hlín, } \\
\text { stredne t’ažké až t’ažké }\end{array}$ & 83 & $\mathrm{O} 2$ & 6 & 0,038117 \\
\hline
\end{tabular}

Tabela 9. Neolitické osídlenie. Pät bonít pôdno-ekologických jednotiek s najsilnejším kladným skóre podla výsledkov analýz hlavných komponentov v zóne NE2.

\begin{tabular}{|c|c|c|c|c|c|}
\hline BPEJ & Pôdny typ & Body & TPK & Kvalita & PC 1 \\
\hline 0657302 & $\begin{array}{l}\text { pseudogleje kultizemné, zo sprašových a polygenetických hlín, v povrchovom } \\
\text { horizonte stredne t’ažké až tažké, lokálne vel'mi t'ažké }\end{array}$ & 52 & O6 & 6 & 0,454160 \\
\hline 0657202 & $\begin{array}{l}\text { pseudogleje kultizemné, zo sprašových a polygenetických hlín, v povrchovom } \\
\text { horizonte stredne t’ažké až tažké, lokálne vel'mi t’ažké }\end{array}$ & 53 & O6 & 6 & 0,223480 \\
\hline 0657502 & $\begin{array}{l}\text { pseudogleje kultizemné, zo sprašových a polygenetických hlín, v povrchovom } \\
\text { horizonte stredne t’ažké až t'ažké, lokálne vel'mi t’ažké }\end{array}$ & 47 & O6 & 7 & 0,138300 \\
\hline 0657303 & $\begin{array}{l}\text { pseudogleje kultizemné, zo sprašových a polygenetických hlín, v povrchovom } \\
\text { horizonte stredne t’ažké až tažké, lokálne vel'mi t'ažké }\end{array}$ & 49 & O6 & 6 & 0,082436 \\
\hline 0757502 & $\begin{array}{l}\text { pseudogleje kultizemné, zo sprašových a polygenetických hlín, v povrchovom } \\
\text { horizonte stredne t’ažké až t'ažké, lokálne vel'mi t’ažké }\end{array}$ & 43 & OT3 & 7 & 0,076974 \\
\hline
\end{tabular}

najväčší percentuálny podiel v pôdnom vzorci zázemia NE2 (54\%), význam majú ešte kategórie OT3 (14 \%) a O5 (13 \%), ide o pôdy horšej kvality (tabela 7; 9). Z uvedeného možno usudzovat', že osídlenie zóny sa neviazalo na produkčné pôdy a význam mali pôdy charakteru O6.

Polohy zóny NE3 (lokality 3, 4, 8, 9) sa nachádzajú vo výškovom pásme K2b a K3a. Je potrebné poznamenat', že dve z nich (lokalita 8 - Fintice, Košariská I, lokalita 9 - Fintice, Košariská II) sú situované na jednom pomerne prudkom svahu $200 \mathrm{~m}$ od seba.
V jednom prípade ide o nález sídliskového objektu skupiny Tiszadob (Vizdal 2000, 153), v druhom prípade sa vo vrstve našli úlomky neolitickej keramiky, zvieracie a l'udské (!) kosti (Nowak/Vizdal 2002, 145). Nevylučujeme, že môže íst' o nálezy z tej istej sídliskovej jednotky. Lokality 3 a 4 sa síce nachádzajú asi $2 \mathrm{~km}$ od seba, ale situované sú na temenách dvoch vyvýšenín toho istého hrebeňa. Konfrontácia s hodnotami sledovaných parametrov príslušných výškových zón ukazuje zhodu len s ohladom na drsnost’ terénu so zónou $\mathrm{K} 2 \mathrm{~b}$, avšak iba v mieste 
Tabela 10. Neolitické osídlenie. Pät bonít pôdno-ekologických jednotiek s najsilnejším kladným skóre podla výsledkov analýz hlavných komponentov v zóne NE3.

\begin{tabular}{|c|c|c|c|c|c|}
\hline BPEJ & Pôdny typ & Body & TPK & Kvalita & PC 1 \\
\hline 0784683 & $\begin{array}{l}\text { kambizeme pseudoglejové, na výrazných svahoch: } 12-25^{\circ} \text {, stredne t’ažké až } \\
\text { tažké, lokálne vel'mi t'ažké }\end{array}$ & 21 & T2 & 9 & 0,6530400 \\
\hline 0688403 & $\begin{array}{l}\text { rendziny kultizemné, lokálne hnedozeme kultizemné, erodované, alebo } \\
\text { kambizeme kultizemné, erodované, zo slieňov a ílov, stredne t’ažké až t'ažké, } \\
\text { lokálne vel'mi t’ažké }\end{array}$ & 46 & OT3 & 7 & 0,3092200 \\
\hline 0651203 & $\begin{array}{l}\text { hnedozeme kultizemné, pseudoglejové, lokálne pseudogleje kultizemné, zo } \\
\text { sprašových a polygénnych hlín, t’ažké }\end{array}$ & 61 & O5 & 6 & 0,0286960 \\
\hline 0688503 & $\begin{array}{l}\text { rendziny kultizemné, lokálne hnedozeme kultizemné, erodované, alebo } \\
\text { kambizeme kultizemné, erodované, zo slieňov a ílov, stredne t’ažké až t’ažké, } \\
\text { lokálne vel'mi t’ažké }\end{array}$ & 43 & OT3 & 7 & 0,0064346 \\
\hline 0692773 & $\begin{array}{l}\text { rendziny modálne, na výrazných svahoch: } 12-25^{\circ} \text {, stredne t’ažké až t’ažké, } \\
\text { lokálne vel'mi t’ažké }\end{array}$ & 28 & $\mathrm{~T} 2$ & 9 & 0,0064346 \\
\hline
\end{tabular}

Tabela 11. Neolitické osídlenie. Pät bonít pôdno-ekologických jednotiek s najsilnejším kladným skóre podla výsledkov analýz hlavných komponentov v zóne NE4.

\begin{tabular}{|c|c|c|c|c|c|}
\hline BPEJ & Pôdny typ & Body & TPK & Kvalita & PC 1 \\
\hline 0787433 & $\begin{array}{l}\text { rendziny kultizemné a r. kultizemné, kambizemné, stredne hlboké, zo zvetralín } \\
\text { vápencov a dolomitov, stredne t’ažké až t’ažké, lokálne vel'mi t'ažké }\end{array}$ & 40 & $\mathrm{O} 7$ & 7 & 0,777240 \\
\hline 0787232 & $\begin{array}{l}\text { rendziny kultizemné a r. kultizemné, kambizemné, stredne hlboké, zo zvetralín } \\
\text { vápencov a dolomitov, stredne t'ažké až t’ažké, lokálne vel'mi t'ažké }\end{array}$ & 46 & $\mathrm{O} 7$ & 7 & 0,270390 \\
\hline 0787233 & $\begin{array}{l}\text { rendziny kultizemné a r. kultizemné, kambizemné, stredne hlboké, zo zvetralín } \\
\text { vápencov a dolomitov, stredne t'ažké až t'ažké, lokálne vel'mi t’ažké }\end{array}$ & 43 & $\mathrm{O} 7$ & 7 & 0,262470 \\
\hline 0787432 & $\begin{array}{l}\text { rendziny kultizemné a r. kultizemné, kambizemné, stredne hlboké, zo zvetralín } \\
\text { vápencov a dolomitov, stredne t’ažké až t'ažké, lokálne vel'mi t'ažké }\end{array}$ & 43 & O7 & 7 & 0,135140 \\
\hline 0790462 & rendziny kultizemné (alebo modálne), plytké, stredne t’ažké až l'ahké & 29 & $\mathrm{~T} 1$ & 8 & 0,073109 \\
\hline
\end{tabular}

nálezu, no v širšom okolí už pozorujeme štatisticky významné rozdiely. Opät, ako i v predchádzajúcich prípadoch, majú náleziská v priemere i mediáne vyššie hodnoty. Sú teda situované vo svažitejšom a drsnejšom terénne ako je ich krajinný kontext. Vysoké hodnoty má aj prevýšenie okolia, najvyššie hodnoty zo sledovaných zón má aj vzdialenost’ $\mathrm{k}$ vode (tabela 6 ).

Ohladom pôdneho krytu sa v skladbe pôd v zázemí archeologických komponentov zóny NE3 a daného krajinného kontextu (K2b a K3a) zistili rozdiely. Z orných pôd chýbajú kategórie $\mathrm{O} 3$ a O4, ktoré v dotknutých krajinných pásmach evidujeme (no ani tu nemajú vel'ký podiel - O3: K3a =0,15 \%; $\mathrm{O} 4: \mathrm{K} 2 \mathrm{~b}=4 \%, \mathrm{~K} 3 \mathrm{a}=2,4 \%)$. V zázemí lokalít tak registrujeme až TPK O5 (= $4 \%$ ), O6 (=0,25\%) a O7 (=3\%), ktoré taktiež nemajú výrazné percentuálne zastúpenie. $\mathrm{V}$ tomto prípade má percentuálne zastúpenie O5 zóny NE3 vyššiu hodnotu ako dosahuje krajinný kontext. Podstatné ale je, že s ním pomerne vysokú zhodu vykazujú pôdy s najväčším zastúpením v zázemí sledovaných komponentov, teda T2_L (= $26 \%)$, OT3 (= $16 \%)$, T2 (= $16 \%)$. Ide o značne nekvalitné pôdy (tabela $7 ; 10)$. Z uvedeného možno vyvodit, že sa osídlenie zóny neviazalo na obrábanie polí. Nemožno však vylúčit', že skladba pôdneho vzorca krajinného kontextu nehrala pri výbere osídlených plôch žiadnu úlohu.

Polohy zóny NE4 (lokality 37, 39, 56, 66) podl'a výsledkov štatistickej analýzy zodpovedajú trom výškovým zónam (K2b, K3a, K3ba). Komparácia jednotlivých parametrov sekundárnej informačnej vrstvy „Priestorové dáta“ ukazuje zhodu vo všetkých porovnávaných premenných s pásmom K3a. Naopak v pásme K2b sa ukazuje zhoda iba v sklone a drsnosti terénu sídelného areálu (teda v okruhu 500 m okolo miesta nálezu) a v pásme K3ba len v drsnosti v mieste nálezu. Z toho vyplýva, že osídl'ovanie odlahlých údolí by malo vyhl'adávat' stráne so sklonom asi 6-7 (pásmo K3ba vykazuje $\mathrm{v}$ priemere menší sklon, naopak pásmo $\mathrm{K} 2 \mathrm{~b}$ väčší) a s indexom drsnosti okolo 3 (opät' K3ba má index menší a K2a väčší). Vzdialenost’ k vodnatejším tokom je tu väčšia ako v hlavnom údolí a môže dosahovat' až 600 m. Prevýšenie vzhl'adom na charakter okupovaných krajinných pásiem nedosahuje síce extrémne hodnoty, ale môže už byt’ pomerne vel'ké (až $18 \mathrm{~m}$ v areáli aktivity a $43 \mathrm{~m}$ v sídelnom areáli). 
Je potrebné podotknút, že ani v jednom prípade pritom nejde o tzv. výšinné sídlisko. Evidované lokality boli orientované na juhovýchod (tabela 6).

Ohladom pôdneho krytu sa v skladbe pôd v zázemí archeologických komponentov zóny NE4 a daného krajinného kontextu (K2b, K3a a K3ba) opät' zistili rozdiely. Z orných pôd chýbajú kategórie O3, $\mathrm{O} 4$ a taktiež aj O5, ktoré v dotknutých krajinných pásmach evidujeme (O3: K3a $=0,15 \%$; $\mathrm{O} 4: \mathrm{K} 2 \mathrm{~b}=4 \%$, $\mathrm{K} 3 \mathrm{a}=2,4 \%$, K3ba: 6,9 \%; O5: K2b: 0,4 \%, K3a: 4 \%, K3ba: 9,6\%). V zázemí lokalít tak registrujeme až TPK O6 (=3,75\%), ale najväčší priemerný podiel majú TPK O7 (= $25 \%)$ a O6_L (= $20 \%)$, T2 (= $17 \%)$ a OT3 (= $12 \%)$, ktoré aj vykazujú pomerne vysokú štatistickú zhodu $\mathrm{s}$ ich zastúpením v krajinnom kontexte. Ide opät o značne nekvalitné pôdy (tabela 7; 11). Z uvedeného možno vyvodit, že sa osídlenie zóny neviazalo na obrábanie polí. Nemožno však vylúčit, že by ani tu skladba pôdneho vzorca krajinného kontextu nehrala pri výbere osídlených plôch žiadnu úlohu.

Vzhladom na to, že zónu 5 zastupuje len jedna lokalita, štatistickú komparáciu v tomto prípade realizovat' nemožno.

V poslednom kroku analýzy porovnáme jednotlivé pásma neolitického osídlenia povodia Sekčova medzi sebou. Ohladom sekundárnej informačnej vrstvy „Priestorové dáta“ sa štatisticky významné rozdiely v parametre sklon na mieste nálezu zistili len medzi NE1, NE3 a NE4, naopak pri sklone v areáli aktivity (r $150 \mathrm{~m})$ a sídelnom areáli (r $500 \mathrm{~m}) \mathrm{sa}$ neodlišujú len zóny NE2 a NE4. Podobnú tendenciu vidiet aj pri parametroch „Drsnost" a „TRI“: Najmenšie rozdiely badat medzi zónami NE2 a NE4, kde sa významný rozdiel prejavil len pri parametri „Drsnost' v okruhu 500 m“, v ktorom sa už zrkadlí odlišný krajinný kontext jednotlivých zón, NE4 sa nachádza v hornatejšom prostredí. Túto skutočnost' odráža aj parameter „Prevýšenie“, pri ktorom sa ešte $\mathrm{v}$ areáli aktivity rozdiely neprejavujú, naopak v sídelnom areáli sú už štatisticky významné. A opät, na príbuzný charakter oboch zón poukazuje parameter „Vzdialenost" $\mathrm{k}$ toku“, pri ktorom sa štatisticky významný rozdiel nezistil.

Ak zóny NE2 a NE4 (resp. i NE5), ktoré majú spolu až $43 \%$ (s NE5 $48 \%$ ) podiel v osídlení regiónu, snád' možno ponímat' ako prejav rovnakej sídliskovej stratégie v rozličných krajinných pásmach, tak zóny NE1 a NE3 predstavujú protipóly na jej okrajoch. Uvedieme, že kým zóna NE1 sa niektorými hodnotami v miestach nálezu približuje zóne NE2 (,Sklon“, „Vzdialenost' k toku“) a zóne NE4 (,Drsnost“", „TRI“), zóna NE3 má v miestach nále- zu niektoré spoločné črty so zónou NE2 („,Sklon“, „Drsnost", „Vzdialenost' ku koridoru“) a so zónou NE4 vykazuje podobnost' len ohl'adom premennej „Vzdialenost' $\mathrm{k}$ toku“. Z porovnania vysvitá, že pri hodnotách z miesta nálezu sa môžu rozdiely stierat'. Avšak ak aj lokality zóny NE1 nepredstavujú dominantnú sídliskovú stratégiu, tak sú v regionálnom kontexte najvýhodnejšie situované (úrodné pôdy, vhodná klíma, blízkost’ komunikačného koridoru). Napokon, tieto výhody sa odrážajú aj v percentuálnom zastúpení tohto typu osídlenia v regióne (33 \%). Naopak komponenty zóny NE5 (19\%) sú lokalizované na neprístupné, prakticky neobývatelné miesta (vel'ká svahovitost' či vzdialenost' k vode, vysoký index drsnosti). Táto okolnost' nás núti uvažovat aj o inej, ako hospodárskej funkcii daných komponentov, $\mathrm{v}$ dvoch prípadoch ide $\mathrm{k}$ tomu o prírodou chránené výšinné polohy.

Ohladom sekundárnej informačnej vrstvy „Environmentálne dáta" možno konštatovat', že skladbe pôdneho vzorca v zázemí komponentov jednotlivých neolitických sídelných zón na úrovni TPK nevykazuje v jednotlivých položkách významné štatistické rozdiely, avšak s jednou dôležitou výnimkou, len v zóne NE1 evidujeme kvalitnejšie ornice kategórie O2 a O3 (hoci ani tu nemajú výrazný podiel). Predovšetkým však len v tejto zóne majú významné zastúpenie ornice kategórie O4 (= $19 \%$, O4_L = $19 \%$ ) a O5 (= $20 \%)$, ktoré, ak sa vôbec vyskytnú, sa inde bud' vyskytujú ojedinele, alebo majú menšie zastúpenie, a to sa prejavuje ako štatisticky významný rozdiel (zóna NE2). Z hl’adiska skladby pôdneho vzorca na úrovni BPEJ majú tak v zóne NE1 význam najmä čiernice (TPK: O2, O3, O4, O5), ktoré sa „... líšia svojou úrodnostou a to často až extrémne. Subtypy čierníc blízke typickému vývoju [...] sú našimi najúrodnejšími pôdami [...] hydromorfnejšie subtypy čierníc už majú vážne limitácie aj v úrodnosti [...] Tie sa znásobujú ak ide o kombináciu glejových a salinických subtypov..." ${ }^{23} \mathrm{~V}$ zóne NE2 dominujú pseudogleje (TPK: O6, OT3), ktoré sa „... v polnohospodárstve využívajú ako trvalé trávne porasty, menej ako orná pôda..." ${ }^{24}$ a v zóne NE4 rendziny (TPK: O7, T1), ktoré sú ,... vo vyšších horských oblastiach [...] polnohospodársky využívané len ako pasienky..."25 (tabely 7-11). Z uvedeného vyplýva, že ohladom pôd najdiverzifikovanejším zázemím disponovala zóna NE1, v ktorej sa mohlo realizovat polnohospodárstvo zároveň s pasienkárstvom, kým vo zvyšných zónach sa mohlo uplatnit len pasienkárstvo. V porovnaní so zónou NE1 však v tomto ohlade nie sú zóny NE2 a NE4 zvýhodnené.

\footnotetext{
${ }^{23} \mathrm{http}: / /$ old.agroporadenstvo.sk/rv/poda/ciernica.htm?start [14-9-2020]

${ }^{24} \mathrm{http}: / /$ old.agroporadenstvo.sk/rv/poda/pseudoglej.htm?start [14-9-2020]

${ }^{25} \mathrm{http}: / /$ old.agroporadenstvo.sk/rv/poda/rendzina.htm?start [14-9-2020]
} 
Súhrnom možno uviest', že štyri sídelné zóny neolitického osídlenia povodia Sekčova, vyseparované lineárnou regresiou premenných „Nadmorská výška“ a „Vzdialenost’ ku komunikačnému koridoru“, reprezentujú podla štatistickej analýzy priestorových a environmentálnych dát pravdepodobne tri (resp. dva) rôzne typy exploatácie krajiny. Komparácia s krajinným kontextom pritom prezrádza zámernú vol'bu osídlených plôch. $\mathrm{V}$ týchto súvislostiach možno $\mathrm{z}$ hospodárskeho hladiska za najvýhodnejšie považovat situovanie sledovaných komponentov do zóny NE1, ktorá je zároveň situovaná na komunikačný koridor. Lokality sa nachádzajú skôr na terasách či svahoch prevyšujúcich o niekol'ko metrov nivu, čo sa prejavuje $\mathrm{v}$ charakteristike okolitého terénu. Sú situované na pôdach, ktoré sú v obmedzenej miere vhodné na kopaničiarstvo (čiernice) a chov. Pokial predpokladáme, že komunikačná trasa viedla údolím, obyvatelia tejto zóny kontrolovali aj obchod. Nevýhodou takto situovaných komponentov je, že v prípade agresie zvonka sa nachádzali v najexponovanejšom teritóriu. Lokality zóny NE2 a NE4 sú situované do krajiny využitelnej na pašu. Pastierske (?) skupiny tu okupovali areály vcelku, ale nie extrémne sklonené (okolo $6^{\circ}$ ) a relatívne blízko vody (ktorá sa však nemusela nachádzat’ $\mathrm{v}$ bezprostrednom susedstve areálu aktivity). Náleziská všetkých doposial’ zmienených zón boli orientované viac-menej na juh.

To v zásade platí aj pre komponenty zóny NE3, ktoré sa však inými parametrami od ostatných zón odlišujú. Sú situované bud' na prudkom svahu, alebo na temene návršia, ktoré značne prevyšuje okolie, $\mathrm{v}$ tomto prípade možno uvažovat' o inej funkcii zóny. Otvorenou zostáva jej interpretácia. V prípade výšinných polôh sa samozrejme ponúka možnoste praktického využitia (refúgiá či „,pevnôstky“), avšak jedným trendom v súčasnej odbornej literatúre je im prisudzovat funkciu symbolickú (Neustupný 1995, 205 nn.). Tomu úplne neodporujú nálezy ludských a zvieracích kostí $\mathrm{v}$ areáloch komponentov 8 a 9 , teda pokial' nejde o stopy predpolia nejakého doposial' neidentifikovaného výšinného sídliska v susedstve.

Jadrom neolitického osídlenia sa pri súčasnom stave výskumu javí kataster Kapušian spolu s katastrom Fintíc, teda približne stredný tok Sekčova. Tu sa koncentrujú jednak lokality zóny NE1, jednak sem vyústujú bočné osídlené údolia a na okraji tejto zóny sa nachádzajú aj výšinné polohy. Osídlenie prakticky nezasahuje do severnej a hornatej časti povodia. Aj vzhladom na túto, $\mathrm{z}$ dnešného pohl'adu neosídlenú plochu vychádza osídlenie regiónu v neolite ako velmi riedke (1 sídlisko na $\left.9 \mathrm{~km}^{2}\right)$, pri jednotlivých etapách ešte redšie (kultúra s východ- nou lineárnou keramikou: 28 km²; bukovohorská kultúra: $24 \mathrm{~km}^{2}$ ). V tomto smere podáva presnejší obraz analýza najbližšieho suseda realizovaná v GIS-e. Z výpočtov tohto algoritmu vychádza pozorovaná vzdialenost' medzi neolitickými komponentmi (21 lokalít) na 1,946 km a predpokladaná na $1,862 \mathrm{~km}$, medzi lokalitami kultúry s východnou lineárnou keramikou na 2,483/3,224 km a bukovohorskej kultúry na 2,555/3,016 km. Medzi týmito kultúrami sa ohladom týchto hodnôt nezistil štatisticky významný rozdiel.

To isté napokon v podstate platí aj pre rozptyl komponentov spomenutých typochronologických sekvencií v krajine. Lokality oboch kultúr sa nachádzajú vo všetkých zónach spolu, avšak náleziská bukovohorskej kultúry v zónach NE2, NE3 a NE4 dominujú. Významne sa javí skutočnost', že na vlastných výšinných polohách predbežne evidujeme len nálezy bukovohorskej kultúry (podobne ako napr. na Gemeri - Malček/Blažová/Botoš, $v$ tlači). Napriek tomu možno konštatovat', že podl'a dnešných poznatkov v povodí Sekčova neolitické osídlenie pretrvávalo v dvoch následných etapách až na jednu výnimku (výšinné polohy) v nezmenených rysoch. Nemožno teda vylúčit', že na strednom a dolnom toku Sekčova po dlhšie obdobie sídlila jedna neolitická skupina, v ktorej hospodárstve sa mohlo realizovat' kopaničiarstvo (v hlavnom údolí), avšak ktorá značne závisela od pastierstva (okupácia bočných údolí). Sídliskový režim a jeho štruktúra by mohla zodpovedat pozorovaniam z iných oblastí (Czekaj-Zastawny 2008, 82 nn.). Osídlovanie chránených výšinných polôh v druhej etape osídlenia by mohlo naznačovat zmenu „politického“ či „ideologického“ kontextu.

\section{Eneolit}

Lineárna regresia premenných „Nadmorská výška“ a „Vzdialenost” ku komunikačnému koridoru“ ukazuje rozptyl eneolitického osídlenia do troch krajinných pásiem. Najzovretejší zhluk lokalít evidujeme v zóne EN1 (lokality 5, 12, 15, 19, 28, 34, 44, 45, 49-51), rovnako zovretá je aj zóna EN2 (lokality $46,47,52,53)$. Na ich rozmedzí sa nachádzajú dva komponenty (lokality 5 a 45), ktoré podla výsledku lineárnej regresie skôr náležia do zóny EN1, podla výsledkov PCA však skôr do zóny EN2. Napokon sme ich vzhladom na polohu zahrnuli do zóny EN1. Excentricky je lokalizovaná zóna EN3 (lokality 1, 29, 52, 53; obr. 7: 1). Pri priemete na fyzickú mapu je vidiet', že zóna EN1 reprezentuje osídlenie vlastného údolia Sekčova, zóna EN2 bočné údolia Šalgovického a Solného potoka, teda lavostranných prítokov na dolnom toku Sekčova (obr. 7: 2). Obe 

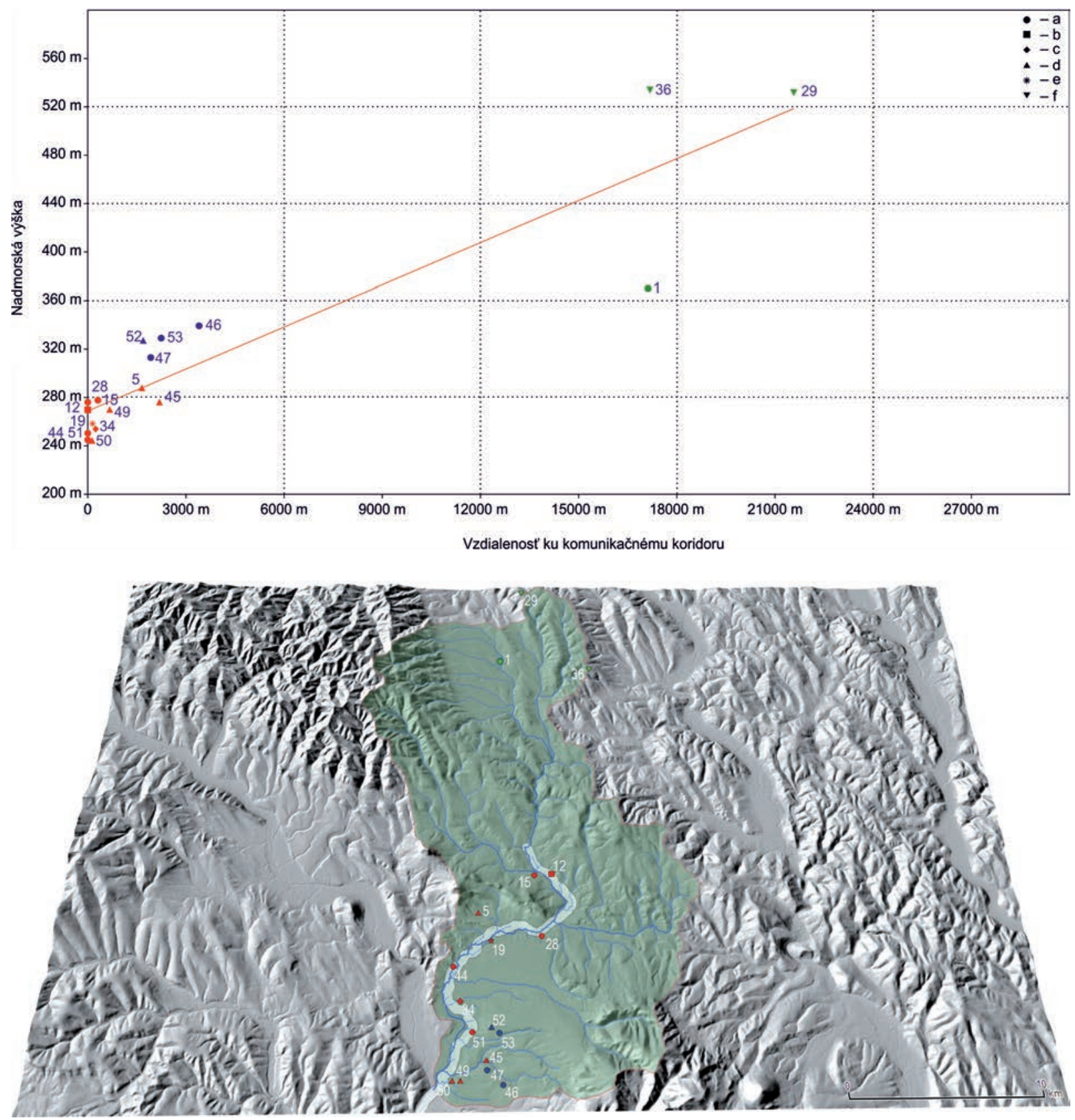

Obr. 7. Model zonácie eneolitického osídlenia v povodí Sekčova. 1 - porovnanie osídlenia vo vztahu k nadmorskej výške a vzdialenosti od komunikačného koridoru; 2 - vyobrazenie výsledkov zonácie na reliéfnej mape. Legenda: a - neurčené zaradenie; b - skupina Lažňany; c - skupina Lažňany a badenská kultúra; d - badenská kultúra; e - kultúra Nyírség-Zatín; f - skupina východoslovenských mohýl kultúry so šnúrovou keramikou. Farby symbolov: červená - zóna EN1; modrá - zóna EN2; zelená - zóna EN3. Numerické označenie lokalít sa zhoduje s ich značením v tabele 2.

zóny sa nachádzajú v Košickej kotline. Zóna EN3 reprezentuje odlahlé náleziská, ktoré sú situované bud' na horný (severný) tok Sekčova (lokalita 1), alebo opät do bočného údolia Hrabovca a jeho prítokov (lokality 29 a 36). Tieto sa nachádzajú už v Ondavskej vrchovine. Súhrnnú štatistiku vybratých premenných sekundárnej informačnej vrstvy „Priestorové dáta“ a „Environmentálne dáta“" zobrazujú tabely 12 až 16.
Podobne ako v kapitole Neolit, tak aj v prvom kroku analýzy porovnávame vyčlenené zóny s krajinou a jej členením. $V$ rozložení podla výškových pásiem krajiny tak zóna EN1 zodpovedá krajinnému pásmu $\mathrm{K} 3 \mathrm{bb}(\mathrm{p}=0,3108)$, zóna EN2 až trom krajinným pásmam, totiž $K 2 b$, K3a a K3ba, avšak najbližšie má $\mathrm{k}$ pásmu K3ba $(\mathrm{K} 2 \mathrm{~b}-\mathrm{p}=0,06702, \mathrm{~K} 3 \mathrm{a}-\mathrm{p}=$ 0,07226, K3ba - p = 0,9714). Zóna EN3 okupuje opät tri pásma (K2a, K2b, K3a), ale najbližšie má k pásmu 
$\mathrm{K} 2 \mathrm{~b}(\mathrm{~K} 2 \mathrm{a}-\mathrm{p}=0,2347, \mathrm{~K} 2 \mathrm{~b}-\mathrm{p}=0,1838, \mathrm{~K} 3 \mathrm{a}-\mathrm{p}=$ 0,07833). Ďalej porovnáme dáta zón eneolitického osídlenia s konkrétnym krajinným kontextom. Výsledky možno zhrnút nasledovne.

Jedenást' komponentov zóny EN1 (lokality 5, $12,15,19,28,34,44,45,49-51$ ) predstavuje $61 \%$ podiel eneolitického osídlenia regiónu. Tieto vykazujú ohladom sklonu voči krajinnému kontextu (K3bb) štatisticky významný rozdiel, a to ako na mieste nálezu, tak aj v širšom okolí ( $\mathrm{p}=$ 0,001343/0,0002742/0,003274). Eneolitické osídlenie, podobne ako v neolite, vyhl'adáva terén svažitejší, ktorý je charakteristický pre dotknuté krajinné pásmo. To platí aj pri parametroch "Drsnost" a „TRI“, kde opät pozorujeme štatisticky významné rozdiely a opät majú archeologické komponenty extrémnejšie hodnoty ako krajinný kontext. V súvislosti s parametrom „Prevýšenie nad okolím" (dosahovalo $\mathrm{v}$ priemere $7 \mathrm{~m} \mathrm{v}$ areáli aktivity a $12 \mathrm{~m}$ v sídelnom areáli) tak možno konštatovat', že v doline Sekčova sa aj počas eneolitu osídlovali vyvýšenejšie a chránenejšie miesta na svahoch so sklonom okolo $4^{\circ}$. Vyberali sa pritom polohy skôr orientované na juh až juhozápad v blízkosti vodného zdroja (tabela 12).

Ohladom pôdneho krytu sa medzi skladbou pôd v zázemí archeologických komponentov zóny EN1 a daného krajinného kontextu (K3bb) štatisticky významné rozdiely nezistili (s výnimkou OT3). Ako vidiet’ v tabele 13, najväčší percentuálny podiel v pôdach majú TPK O6 (17\%), O5 (16\%), O4_L (15\%) a O4 (14\%), teda v miestnom kontexte najúrodnejšie typy pôd, napriek tomu ide iba o pôdy menej kvalitné (tabela 13 a 14). Zdá sa, že sa v pásme uprednostňovali TPK O6 a O5 nad O4.

Štyri komponenty zóny EN2 (lokality 46, 47, 52, 53) predstavujú $22 \%$ podiel eneolitického osídlenia regiónu. Nachádzajú sa $\mathrm{v}$ bočných údoliach Šalgovíckeho a Solného potoka, kde je osídlenie rozptýlené $\mathrm{v}$ troch krajinných zónach, a to $\mathrm{K} 2 \mathrm{~b}$, K3a, K3ba. Podla výsledkov analýzy rozptylu sa zóna EN2 ohladom parametrov ",Sklon“, „Drsnost" a „TRI“ štatisticky významne líši od prvých dvoch uvedených krajinných pásiem, a to ako na mieste nálezu, tak aj v širšom okolí. Naopak, vo všetkých prípadoch sa zhoduje s pásmom K3ba. Možno konštatovat', že pri uvedených premenných dosahujú krajinné pásma $\mathrm{K} 2 \mathrm{~b}$ a K3a extrémnejšie hodnoty ako sídelné areály archeologických komponentov $\mathrm{v}$ nich. $\mathrm{V}$ bočných údoliach sa teda počas eneolitu, bez ohl’adu na krajinnú zónu, osídlovali miesta na svahoch so sklonom okolo $4^{\circ}$ a s indexom drsnosti okolo 2. Vyberali sa pritom polohy skôr orientované na juhozápad či na západ, a to pomerne značne vzdialené od vodného zdroja. Aj ked' oproti zóne EN1 dosahuje parameter „Prevýšenie nad okolím“ vyššie hodnoty $\mathrm{v}$ bezprostrednom (priemer okolo $13 \mathrm{~m}$ ) aj širšom okolí (priemer okolo $46 \mathrm{~m}$; tabela 12), ani $v$ jednom prípade tu neevidujeme výšinnú polohu. Prevýšenie je tu dané kopcovitým charakterom terénu.

Ohladom pôdneho krytu sa medzi skladbou pôd v zázemí archeologických komponentov zóny EN2 a daného krajinného kontextu (K2b, K3a, K3ba) vo väčšine prípadov štatisticky významné rozdiely nezistili. Avšak dôležitú skupinu štatisticky odlišných TPK predstavujú práve O3, O4 a O5, v miestnom kontexte najúrodnejšie typy pôd. $\mathrm{V}$ tomto prípade sa zistili významné rozdiely pri O3 (K3a - p = 0,00003839, K3ba $-\mathrm{p}=0$,003787), O4 $(\mathrm{K} 2 \mathrm{~b}-\mathrm{p}=0,01274, \mathrm{~K} 3 \mathrm{a}-\mathrm{p}=0,02953)$ a O5 (K2b $p=0,000000001361, K 3 a-p=0,0001188, K 3 b a-p=$ $0,01411)$. Tieto kategórie majú $\mathrm{v}$ zázemí archeologických komponentov vždy vyššie zastúpenie ako v pôdnom vzorci krajinného kontextu. Zhodu evidujeme iba pri TPK O4 so zónou K3ba ( $\mathrm{p}=0,1314)$. Aj v tabele 13 je vidiet', že najväčší priemerný percentuálny podiel v pôdach majú síce TPK O6 (35\%, ide o kategóriu s najväčším podielom na pôdach K3a a K3ba), ale významné zastúpenie má aj O5 (21\%) a dokonca O3 (9\%). Na úrovni BPEJ sa to prejavuje tak, že najväčšiu váhu tu majú síce pseudogleje (O6), ale hned' za nimi čiernice (O3) a luvizeme (O6; tabela 15). Na rozdiel od pozorovaní pomerov v zóne EN1 možno konštatovat', že skladba pôd v zázemí eneolitických komponentov pri polnohospodársky významnej skupine TPK nekorešponduje s pôdnym krytom krajinného kontextu a že sa $\mathrm{v}$ danom prostredí zrejme vyhladávali miesta s úrodnejšími pôdami, než aké boli charakteristické pre daný typ krajiny. Otázkou zostáva možnost' využitia najhojnejšie zastúpenej TPK O6, ktorá asi dobovou agrotechnikou bola len vel'mi t’ažko exploatovatelná. Do úvahy prichádza, podobne ako v neolite, pastierstvo (pseudogleje).

Tri komponenty zóny EN3 (lokality 1, 29, 52, 53) predstavujú $17 \%$ podiel eneolitického osídlenia regiónu. $\mathrm{V}$ dvoch prípadoch sa nachádzajú v povodí Hrabovca, lavostranného prítoku Sekčova. Vzhladom na to, že tieto komponenty majú špecifické črty, ide o mohylové pohrebiská, pre ktoré sa pravdepodobne vyhl'adávali miesta iného ako hospodárskeho významu, nemožno ich posudzovat’ z hl'adiska sídliskovej stratégie. Preto sa obmedzíme len na konštatovanie, že zóna EN3 je vzhladom na jadro eneolitického osídlenia situovaná do odlahlých častí povodia, kde okupuje krajinné pásma K2a, K2b a K3a. Extrahované hodnoty krajinných a environmentálnych parametrov uvádzame v príslušných tabelách. Spomenuté mohylníky náležia skupine východoslovenských mohýl kultúry so šnúrovou keramikou. 
Tabela 12. Eneolitické osídlenie, súhrnná štatistika premenných zo sekundárnej informačnej vrstvy „Priestorové dáta“.

\begin{tabular}{|c|c|c|c|c|c|c|c|}
\hline & $\mathrm{N}$ & Min & Max & 25 percentil & 75 percentil & Priemer & Medián \\
\hline Nadmorská výška_EN1 & 11 & 244,4488 & 288,0616 & 250,4546 & 276,309 & 264,5607 & 270,1421 \\
\hline Nadmorská výška_EN2 & 4 & 313,0482 & 339,3208 & 316,6102 & 336,7782 & 327,2039 & 328,2232 \\
\hline Nadmorská výška_EN3 & 3 & 370,003 & 533,9304 & 370,003 & 533,9304 & 478,557 & 531,7377 \\
\hline Vzdialenost'_koridor_EN1 & 11 & 0 & 2191 & 0 & 671 & 484,4545 & 134 \\
\hline Vzdialenost'_koridor_EN2 & 4 & 1696 & 3402 & 1753,25 & 3112,5 & 2316,75 & 2084,5 \\
\hline Vzdialenost'_koridor_EN3 & 3 & 17120 & 21573 & 17120 & 21573 & 18624,67 & 17181 \\
\hline Vzdialenost'_tok_EN1 & 11 & 38 & 583 & 90 & 248 & 191,8182 & 144 \\
\hline Vzdialenost'_tok_EN2 & 4 & 412 & 1777 & 425,25 & 1551,5 & 882,25 & 670 \\
\hline Vzdialenost'_tok_EN3 & 3 & 265 & 3390 & 265 & 3390 & 1423 & 614 \\
\hline Prevýšenie_150m_EN1 & 11 & 0,9751274 & 13,36188 & 4,062199 & 9,556605 & 6,647967 & 5,397358 \\
\hline Prevýšenie_150m_EN2 & 4 & 7,848021 & 18,24258 & 8,81465 & 17,10133 & 12,87067 & 12,69605 \\
\hline Prevýšenie_150m_EN3 & 3 & 6,611388 & 17,43726 & 6,611388 & 17,43726 & 12,55552 & 13,61792 \\
\hline Prevýšenie_500m_EN1 & 11 & 3,236602 & 29,5909 & 5,564731 & 16,94278 & 12,23886 & 9,326694 \\
\hline Prevýšenie_500m_EN2 & 4 & 38,56329 & 56,47745 & 38,99021 & 54,73566 & 46,20551 & 44,89064 \\
\hline Prevýšenie_500m_EN3 & 3 & 15,92236 & 92,90509 & 15,92236 & 92,90509 & 65,46084 & 87,55505 \\
\hline Sklon_EN1 & 11 & 0,58636 & 10,28031 & 2,01078 & 4,66935 & 4,09417 & 4,35185 \\
\hline Sklon_EN2 & 4 & 3,12369 & 5,40211 & 3,227353 & 5,14968 & 4,114133 & 3,965365 \\
\hline Sklon_EN3 & 3 & 1,93016 & 2,67307 & 1,93016 & 2,67307 & 2,25755 & 2,16942 \\
\hline Sklon_150m_EN1 & 11 & 0,9199049 & 9,487244 & 3,153245 & 6,139915 & 4,604061 & 4,710802 \\
\hline Sklon_150m_EN2 & 4 & 3,825921 & 4,638567 & 3,888089 & 4,498805 & 4,154649 & 4,077054 \\
\hline Sklon_150m_EN3 & 3 & 3,166602 & 5,550198 & 3,166602 & 5,550198 & 4,65166 & 5,238181 \\
\hline Sklon_500m_EN1 & 11 & 1,24716 & 6,841107 & 2,829247 & 5,209832 & 4,144815 & 4,350358 \\
\hline Sklon_500m_EN2 & 4 & 4,397659 & 5,58855 & 4,440569 & 5,425989 & 4,873453 & 4,753802 \\
\hline Sklon_500m_EN3 & 3 & 4,705161 & 9,873999 & 4,705161 & 9,873999 & 7,842466 & 8,948237 \\
\hline Drsnost'_EN1 & 11 & 0,26847 & 4,57938 & 0,85964 & 2,00251 & 1,774238 & 1,84074 \\
\hline Drsnost'_EN2 & 4 & 1,34463 & 2,31761 & 1,478473 & 2,208628 & 1,85598 & 1,88084 \\
\hline Drsnost'_EN3 & 3 & 0,86726 & 1,15961 & 0,86726 & 1,15961 & 0,98624 & 0,93185 \\
\hline Drsnost'_150m_EN1 & 11 & 0,3983691 & 4,252066 & 1,356341 & 2,710262 & 2,025982 & 2,042624 \\
\hline Drsnost'_150m_EN2 & 4 & 1,641833 & 1,995316 & 1,66874 & 1,936189 & 1,786355 & 1,754135 \\
\hline Drsnost'_150m_EN3 & 3 & 1,361231 & 2,416111 & 1,361231 & 2,416111 & 2,012911 & 2,261391 \\
\hline Drsnost'_500m_EN1 & 11 & 0,539644 & 2,976496 & 1,242472 & 2,33697 & 1,823444 & 1,9024 \\
\hline Drsnost'_500m_EN2 & 4 & 1,894625 & 2,43485 & 1,92197 & 2,364506 & 2,121739 & 2,078741 \\
\hline Drsnost'_500m_EN3 & 3 & 2,082512 & 4,31961 & 2,082512 & 4,31961 & 3,436826 & 3,908356 \\
\hline Orientácia_EN1 & 11 & 7,32138 & 320,0475 & 188,3702 & 314,5774 & 234,8667 & 273,0898 \\
\hline Orientácia_EN2 & 4 & 218,089 & 337,9832 & 228,4367 & 326,3013 & 276,7019 & 275,3677 \\
\hline Orientácia_EN3 & 3 & 87,43517 & 219,9298 & 87,43517 & 219,9298 & 132,5674 & 90,33724 \\
\hline Orientácia_150m_EN1 & 11 & 90,37169 & 306,3431 & 171,4627 & 292,0418 & 225,4752 & 230,0586 \\
\hline Orientácia_150m_EN2 & 4 & 211,1244 & 297,8654 & 223,3962 & 289,6411 & 258,5424 & 262,5899 \\
\hline Orientácia_150m_EN3 & 3 & 95,40989 & 183,7782 & 95,40989 & 183,7782 & 142,3256 & 147,7887 \\
\hline
\end{tabular}


Tabela 13. Eneolitické osídlenie, súhrnná štatistika premenných zo sekundárnej informačnej vrstvy „Environmentálne dáta. Percentuálne zastúpenie TPK v sídelnom areáli“.

\begin{tabular}{|c|c|c|c|c|c|c|c|}
\hline & N & Min & Max & 25 percentil & 75 percentil & Priemer & Medián \\
\hline O2_\%_EN1 & 11,00 & 0,00 & 4,00 & 0,00 & 0,00 & 0,36 & 0,00 \\
\hline O3_\%_EN1 & 11,00 & 0,00 & 50,00 & 0,00 & 12,00 & 8,64 & 0,00 \\
\hline O3_\%_EN2 & 4,00 & 0,00 & 18,00 & 0,00 & 17,50 & 8,50 & 8,00 \\
\hline O3_L_\%_EN1 & 11,00 & 0,00 & 15,00 & 0,00 & 0,00 & 1,64 & 0,00 \\
\hline O4_\%_EN1 & 11,00 & 0,00 & 42,00 & 0,00 & 21,00 & 13,55 & 12,00 \\
\hline O4_\%_EN2 & 4,00 & 0,00 & 21,00 & 0,50 & 16,50 & 6,50 & 2,50 \\
\hline O4_L_\%_EN1 & 11,00 & 0,00 & 70,00 & 0,00 & 20,00 & 15,18 & 4,00 \\
\hline O5_\%_EN1 & 11,00 & 0,00 & 52,00 & 2,00 & 31,00 & 15,73 & 9,00 \\
\hline O5_\%_EN2 & 4,00 & 9,00 & 66,00 & 11,50 & 55,25 & 29,25 & 21,00 \\
\hline O6_\%_EN1 & 11,00 & 0,00 & 77,00 & 0,00 & 35,00 & 16,64 & 5,00 \\
\hline O6_\%_EN2 & 4,00 & 6,00 & 46,00 & 12,25 & 44,00 & 30,25 & 34,50 \\
\hline O6_L_\%_EN1 & 11,00 & 0,00 & 25,00 & 0,00 & 13,00 & 6,09 & 0,00 \\
\hline O6_L_\%_EN2 & 4,00 & 0,00 & 18,00 & 0,00 & 18,00 & 9,00 & 9,00 \\
\hline O7_\%_EN1 & 11,00 & 0,00 & 29,00 & 0,00 & 14,00 & 5,55 & 0,00 \\
\hline O7_\%_EN2 & 4,00 & 0,00 & 11,00 & 0,00 & 8,25 & 2,75 & 0,00 \\
\hline O7_\%_EN3 & 3,00 & 0,00 & 3,00 & 0,00 & 3,00 & 1,00 & 0,00 \\
\hline O7_L_\%_EN1 & 11,00 & 0,00 & 4,00 & 0,00 & 1,00 & 0,64 & 0,00 \\
\hline O7_L_\%_EN2 & 4,00 & 0,00 & 10,00 & 0,00 & 8,25 & 3,25 & 1,50 \\
\hline O7_L_\%_EN3 & 3,00 & 0,00 & 17,00 & 0,00 & 17,00 & 7,67 & 6,00 \\
\hline OT2_\%_EN1 & 11,00 & 0,00 & 32,00 & 0,00 & 0,00 & 4,18 & 0,00 \\
\hline OT2_\%_EN2 & 4,00 & 0,00 & 8,00 & 0,00 & 7,75 & 3,75 & 3,50 \\
\hline OT2_\%_EN3 & 3,00 & 0,00 & 54,00 & 0,00 & 54,00 & 18,00 & 0,00 \\
\hline OT2_L_\%_EN1 & 11,00 & 0,00 & 25,00 & 0,00 & 8,00 & 5,09 & 0,00 \\
\hline OT2_L_\%_EN2 & 4,00 & 0,00 & 9,00 & 0,00 & 7,00 & 2,50 & 0,50 \\
\hline OT3_\%_EN1 & 11,00 & 0,00 & 38,00 & 0,00 & 2,00 & 4,27 & 0,00 \\
\hline OT3_\%_EN2 & 4,00 & 0,00 & 7,00 & 0,00 & 5,25 & 1,75 & 0,00 \\
\hline OT3_\%_EN3 & 3,00 & 0,00 & 33,00 & 0,00 & 33,00 & 11,33 & 1,00 \\
\hline OT3_L_\%_EN1 & 11,00 & 0,00 & 3,00 & 0,00 & 2,00 & 0,82 & 0,00 \\
\hline OT3_L_\%_EN2 & 4,00 & 0,00 & 3,00 & 0,00 & 2,50 & 1,00 & 0,50 \\
\hline T1_\%_EN1 & 11,00 & 0,00 & 2,00 & 0,00 & 0,00 & 0,18 & 0,00 \\
\hline T1_\%_EN2 & 4,00 & 0,00 & 5,00 & 0,00 & 3,75 & 1,25 & 0,00 \\
\hline T1_\%_EN3 & 3,00 & 0,00 & 2,00 & 0,00 & 2,00 & 0,67 & 0,00 \\
\hline T1_L_\%_EN1 & 11,00 & 0,00 & 1,00 & 0,00 & 0,00 & 0,09 & 0,00 \\
\hline T1_L_\%_EN3 & 3,00 & 0,00 & 83,00 & 0,00 & 83,00 & 51,33 & 71,00 \\
\hline T2_\%_EN1 & 11,00 & 0,00 & 11,00 & 0,00 & 0,00 & 1,55 & 0,00 \\
\hline T2_\%_EN3 & 3,00 & 0,00 & 8,00 & 0,00 & 8,00 & 2,67 & 0,00 \\
\hline T2_L_\%_EN3 & 3,00 & 0,00 & 22,00 & 0,00 & 22,00 & 7,33 & 0,00 \\
\hline
\end{tabular}


Tabela 14. Eneolitické osídlenie. Pät bonít pôdno-ekologických jednotiek s najsilnejším kladným skóre podla výsledkov analýz hlavných komponentov v zóne EN1.

\begin{tabular}{|c|c|c|c|c|c|}
\hline BPEJ & Pôdny typ & Body & TPK & Kvalita & PC 1 \\
\hline 529505 & $\begin{array}{l}\text { čiernice kultizemné a kultizemné glejové, zo sprašových a svahových hlín, } \\
\text { stredne t’ažké až t’ažké }\end{array}$ & 70 & O4 & 6 & 0,924480 \\
\hline 529403 & $\begin{array}{l}\text { čiernice kultizemné a kultizemné glejové, zo sprašových a svahových hlín, } \\
\text { stredne t'ažké až t'ažké }\end{array}$ & 74 & $\mathrm{O} 3$ & 6 & 0,205890 \\
\hline 529002 & $\begin{array}{l}\text { čiernice kultizemné a kultizemné glejové, zo sprašových a svahových hlín, } \\
\text { stredne t'ažké až t'ažké }\end{array}$ & 83 & $\mathrm{O} 2$ & 6 & 0,052827 \\
\hline 529202 & $\begin{array}{l}\text { čiernice kultizemné a kultizemné glejové, zo sprašových a svahových hlín, } \\
\text { stredne t’ažké až t’ažké }\end{array}$ & 80 & $\mathrm{O} 3$ & 6 & 0,069724 \\
\hline 511005 & fluvizeme kultizemné glejové, stredne t’ažké, lokálne l'ahké & 64 & 05 & 5 & 0,066034 \\
\hline
\end{tabular}

Tabela 15. Eneolitické osídlenie. Pät bonít pôdno-ekologických jednotiek s najsilnejším kladným skóre podla výsledkov analýz hlavných komponentov v zóne EN2.

\begin{tabular}{|c|c|c|c|c|c|}
\hline BPEJ & Pôdny typ & Body & TPK & Kvalita & PC 1 \\
\hline 0557202 & $\begin{array}{l}\text { pseudogleje kultizemné, zo sprašových a polygenetických hlín, v povrchovom } \\
\text { horizonte stredne t’ažké až tažké, lokálne vel'mi t’ažké }\end{array}$ & 54 & O6 & 6 & 0,69071 \\
\hline 0529202 & $\begin{array}{l}\text { čiernice kultizemné a kultizemné glejové, zo sprašových a svahových hlín, } \\
\text { stredne tažké až t’ažké }\end{array}$ & 80 & O3 & 6 & 0,26492 \\
\hline 0556202 & $\begin{array}{l}\text { luvizeme kultizemné, pseudoglejové a pseudogleje kultizemné, luvizemné, } \\
\text { zo sprašových a polygenetických hlín, v povrchovom horizonte stredne tažké }\end{array}$ & 58 & O5 & 6 & 0,24796 \\
\hline 0756002 & $\begin{array}{l}\text { luvizeme kultizemné, pseudoglejové a pseudogleje kultizemné, luvizemné, } \\
\text { zo sprašových a polygenetických hlín, v povrchovom horizonte stredne tažké }\end{array}$ & 55 & O6 & 6 & 0,11168 \\
\hline 0557413 & $\begin{array}{l}\text { pseudogleje kultizemné, zo sprašových a polygenetických hlín, v povrchovom } \\
\text { horizonte stredne t’ažké až t'ažké, lokálne vel'mi t'ažké }\end{array}$ & 46 & $\mathrm{O} 7$ & 6 & 0,10247 \\
\hline
\end{tabular}

Tabela 16. Eneolitické osídlenie. Pät bonít pôdno-ekologických jednotiek s najsilnejším kladným skóre podla výsledkov analýz hlavných komponentov v zóne EN3.

\begin{tabular}{|c|c|c|c|c|c|}
\hline BPEJ & Pôdny typ & Body & TPK & Kvalita & PC 1 \\
\hline 0789202 & $\begin{array}{l}\text { pseudogleje kultizemné (alebo modálne), z polygenetických hlín s prímesou } \\
\text { skeletu, stredne t'ažké až t'ažké }\end{array}$ & 49 & OT2 & 7 & 0,62615 \\
\hline 0789242 & $\begin{array}{l}\text { pseudogleje kultizemné (alebo modálne), z polygenetických hlín s prímesou } \\
\text { skeletu, stredne t'ažké až t’ažké }\end{array}$ & 42 & OT3 & 7 & 0,49003 \\
\hline 0789412 & $\begin{array}{l}\text { pseudogleje kultizemné (alebo modálne), z polygenetických hlín s prímesou } \\
\text { skeletu, stredne t'ažké až t'ažké }\end{array}$ & 44 & OT3 & 8 & 0,27224 \\
\hline 0714062 & fluvizeme kultizemné, stredne t’ažké až l'ahké, plytké & 36 & $\mathrm{~T} 1$ & 7 & 0,24502 \\
\hline 0778262 & $\begin{array}{l}\text { kambizeme kultizemné (alebo modálne) a rankre kambizemné, plytké, zo } \\
\text { zvetralín flyša, stredne t'ažké až t’ažké, lokálne vel'mi t'ažké }\end{array}$ & 31 & $\mathrm{~T} 1$ & 8 & 0,24502 \\
\hline
\end{tabular}

V druhom kroku analýzy porovnáme jednotlivé pásma eneolitického osídlenia povodia Sekčova medzi sebou. Vzhl'adom na vyššie uvedené komparujeme len zóny EN1 a EN2. Ohladom sekundárnej informačnej vrstvy "Priestorové dáta" sa pri parametroch „Sklon", Drsnost", „TRI" a "Orientácia“ štatisticky medzi zónami významné rozdiely nezistili, a to na všetkých sledovaných úrovniach (miesto nálezu, areál aktivity, sídelný areál). Rozdiel sa nezistil ani pri premennej „Prevýšenie v okruhu
150 m“. Naopak štatisticky významné rozdiely sa pozorujú pri premenných „Prevýšenie v okruhu 500 m" ( $p=0,009047)$, ,Vzdialenost' ku komunikačnému koridoru“ $(p=0,0102)$ a "Vzdialenost' $k$ toku“ $(\mathrm{p}=0,01572)$. Zdá sa, že eneolitické obyvatel'stvo vo všetkých krajinných pásmach vyhl'adávalo terén podobného typu (pomerne ploché územie sklonené asi pod $4^{\circ}$ na juh až juhozápad), ktorého črty zväčša nekorešpondujú s krajinným kontextom. Rozdiely ohladom prevýšenia určuje práve tento krajinný 
kontext (pahorkovitý terén verzus dno hlavného údolia). Rozdiel pozorovaný pri parametri „Vzdialenost' $k$ toku" pravdepodobne neznamená, že voda pri výbere osídlenej plochy $\mathrm{v}$ bočných údoliach nemala taký význam ako v hlavnom údolí. Skôr ho ovplyvnilo naše kritérium, podla ktorého sme merali vzdialenost' $\mathrm{k}$ výdatnejšiemu toku. Na existenciu týchto osád azda mohli stačit menej výdatné zdroje vody, ktoré sa podla výpočtov algoritmu nachádzajú $\mathrm{v}$ bezprostrednom okolí dotknutých archeologických komponentov.

Ako sme zistili, sídliskovou stratégiou sa obe eneolitické zóny EN1 a EN2 významne neodlišujú. V tomto ohlade je dôležité, že sme zhodu s krajinným kontextom pozorovali medzi skupinou EN2 a pásmom K3ba, ktoré by tak malo predstavovat najvhodnejší sídelný priestor regiónu. Napriek tomu však toto pásmo v eneolitickom osídlení nedominuje. Aj z toho vyplýva, že vol'bu sídelného miesta určovali skôr iné príčiny. Vysvetlenie môže poskytnút aj informačná vrstva „Environmentálne“ dáta.

Skladba pôdneho vzorca v zázemí komponentov eneolitických sídelných zón EN1 a EN2 totiž na úrovni TPK nevykazuje $\mathrm{v}$ jednotlivých položkách významné štatistické rozdiely, a to ani v prípade úrodnejších kategórií $\mathrm{O} 3$ a $\mathrm{O} 4 \mathrm{(O} 2$ sa v zóne EN2 nevyskytuje). $S$ ohladom na kontext, podla ktorého majú tieto kategórie vo vyšších krajinných pásmach minimálne alebo malé priemerné zastúpenie $(\mathrm{O} 3$ $\mathrm{K} 3 \mathrm{a}=0,15 \%, \mathrm{~K} 3 \mathrm{ba}=0,87 \%$ verzus $\mathrm{K} 3 \mathrm{bb}=10,8 \%$; $\mathrm{O} 4-\mathrm{K} 2 \mathrm{~b}=4,2 \%, \mathrm{~K} 3 \mathrm{a}=2,4 \%, \mathrm{~K} 3 \mathrm{ba}=6,9 \%$ verzus $\mathrm{K} 3 \mathrm{bb}=23,8 \%$ ), a s ohladom na zistenie, že zastúpenie týchto kategórii v zázemí komponentov EN2 sa štatisticky významne odlišuje od ich výskytu v danej krajine, by to malo znamenat, že aj pri osídlení bočných dolín zohrával výskyt úrodnejších pôdnych typov významnú, možno rozhodujúcu úlohu. Z hladiska skladby pôdneho vzorca na úrovni BPEJ majú tak v osídlení význam najmä čiernice (TPK: O2, O3, O4, O5). Z uvedeného vyplýva, že v oboch posudzovaných prípadoch (EN1 a EN2) mala zrejme sídlisková stratégia na zreteli polnohospodársky aspekt, ktorý mohol byt’ aj určujúci. To však nevylučuje možnost', že významnú úlohu v ekonomike tohto spoločenstva mohli zohrávat' aj iné aspekty ako napríklad chov. Jednotlivé krajinné pásma totižto disponujú značnými plochami pôd využitelných na pašu. To sa napokon prejavilo aj v skladbe pôd v zázemí archeologických komponentov.

Súhrnom možno uviest', že dve posudzované sídelné zóny eneolitického osídlenia povodia Sekčova, vyseparované lineárnou regresiou premenných „Nadmorská výška“ a „Vzdialenost' ku komunikačnému koridoru", reprezentujú podla štatistickej analýzy priestorových a environmentálnych dát pravdepodobne jeden typ exploatácie krajiny. Komparácia s krajinným kontextom pritom prezrádza zámernú vol'bu osídlených plôch. V týchto súvislostiach možno z hospodárskeho hladiska, podobne ako v neolite, za najvýhodnejšie považovat' situovanie sledovaných komponentov do zóny EN1, ktorá je zároveň situovaná na komunikačný koridor. Lokality sa tu nachádzajú na mierne sklonených svahoch, ktoré sú vyvýšené nad dno údolia. Pomerne hojne disponujú pôdami do istej, aj ked’ obmedzenej miery vhodnými na plúženie (čiernice) či azda aj na kopaničiarstvo a zároveň plochami, na ktorých sa mohol realizovat chov. Výhodou tejto zóny je aj kontrola obchodnej trasy. Osídlenie zóny EN2 taktiež vyhladáva ostrovy úrodnejších pôd, oproti zóne EN1 je práve $\mathrm{v}$ tomto ohlade znevýhodnené, kedže pahorkatina nimi vo väčšej miere neoplýva. Napriek tomu za súčasného stavu výskumu nepozorujeme na rozdiel od neolitu výrazné stopy alternatívnej exploatácie krajiny (pastierstvo). Nevýhodou archeologických lokalít, situovaných do tejto zóny, je aj odlahlost’ od obchodnej trasy. V regióne predbežne neevidujeme výšinné polohy, ktoré by mohli byt príznakom štruktúrovanejšieho modelu osídlenia.

Jadrom eneolitického osídlenia sa pri súčasnom stave výskume javí byt kataster Solivaru a východný okraj katastra Prešova na rozmedzí so Šalgovíkom, teda približne dolný tok Sekčova. Evidujeme odtial' väčší počet lokalítjednak v sekčovskom údolí, jednak v bočných údoliach Šalgovíckeho a Solného potoka. Komponenty sa inak osve vyskytujú v hlavnom údolí asi po stredný tok Sekčova. Osídlenie v staršom a strednom eneolite prakticky nezasahuje do severnej a hornatej časti povodia. $\mathrm{V}$ posudzovanom súbore dominujú náleziská s badenskou keramikou (šest’ lokalít). Len pri tejto kultúre pozorujeme distribúciu komponentov do viacerých zón. Lokality skupiny Lažňany (2) a kultúry Nyírség-Zatín (1) sa nachádzajú v zóne EN1, teda v sekčovskom údolí. Vzhl'adom na zmienené, z dnešného pohladu prakticky neobývané severné územie povodia, sa osídlenie regiónu v eneolite javí ako vel'mi riedke (jedna lokalita približne na $11 \mathrm{~km}^{2}$ ). Badenská kultúra ako jediná početnejšie zastúpená typochronologická sekvencia má hustotu ešte menšiu $\left(1\right.$ lokalita na $\left.32 \mathrm{~km}^{2}\right){ }^{26} \mathrm{~V}$ tomto smere podáva presnejší obraz analýza najbližšieho suseda realizovaná v GIS-e. Z výpočtov tohto algoritmu vychádza pozorovaná vzdialenost medzi eneolitickými komponentmi (18 lokalít) na $1,845 \mathrm{~km}$ a predpokladaná na $1,845 \mathrm{~km}$, medzi lokalitami kultúry badenskej na $1,873 / 3,195 \mathrm{~km}$.

Podla dnešných poznatkov v povodí Sekčova sa osídlenie neskorej doby kamennej rozvinulo v jej

\footnotetext{
${ }^{26}$ Ako pri neolite, aj v tomto prípade delíme plochu so sklonom 3 až $10^{\circ}$ počtom lokalít.
} 


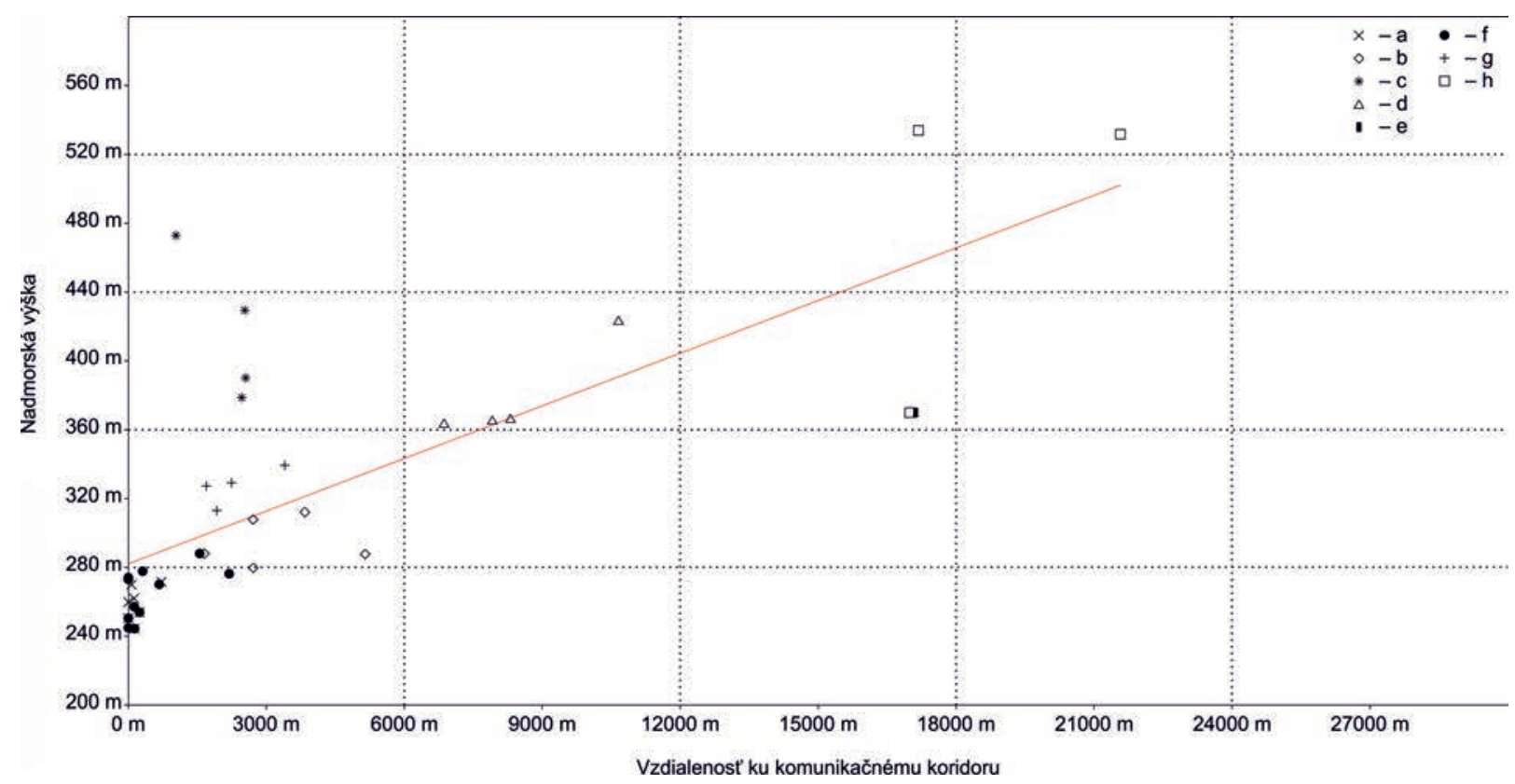

Obr. 8. Porovnanie modelov zonácie neolitického a eneolitického osídlenia v povodí Sekčova vo vztahu k nadmorskej výške a vzdialenosti od komunikačného koridoru. Legenda: a - zóna NE1; b - zóna NE2; c - zóna NE3; d - zóna NE4; e - zóna NE5; f - zóna EN1; g - zóna EN2; h - zóna EN3.

strednom období, kedy ho tu zastupuje badenská kultúra, na ňu vzţahujeme aj naše pozorovanie. Hoci sa v ekonomike tejto archeologickej kultúry predpokladá výrazný podiel pastierstva, v povodí Sekčova analýza environmentálnych dát skôr poukazuje na dôležitost' polnohospodárstva. V tomto ohlade má význam porovnanie rozptylu neolitických a eneolitických lokalít v regióne. Lineárna regresia paramaterov „Nadmorská výška“ a „Vzdialenost” ku komunikačnému koridoru“ ukazuje, že zhodné územie obsadili len skupiny NE1 a EN1. Iné neolitické a eneolitické zhluky okupujú rozdielne krajinné pásma (obr. 8). Štatisticky významné rozdiely medzi nimi napokon potvrdila aj analýza rozptylu pri parametri „Nadmorská výška“. Dobre sa rozdiel prístupu ku krajine ukazuje pri zhlukoch NE2 a EN2, ktoré reprezentujú osídlenie bočných dolín relatívne blízko hlavného údolia. V tomto prípade sú eneolitické lokality síce situované v o niečo väčšej nadmorskej výške, zato však na rozdiel od neolitických komponentov vykazujú v zázemí významný podiel kvalitnejších orných pôd. Akcent na polnohospodárstvo v eneolite možno prezrádza aj zmena tažiska osídlenia. Jeho presun zo stredného toku (neolit) na juh (eneolit) možno interpretovat aj ako posun od pastvín v horských oblastiach k ostrovu úrodnejších pôd na dolnom toku Sekčova.

Rozdiely v prístupe ku krajine, pozorované medzi neolitom a eneolitom v úvodí Sekčova, môžu samo- zrejme skrývat viacero interpretačných línií. Jednou z vysvetlení zmeny môže byt pokrok agrotechniky, ktorý v eneolite umožnil využívat pôdy v neolite neobrábatelné, s tým by súvisel ústup pastierstva. Inou môže byt zmena klímy, ktorá by naopak umožnila neolitickej populácii postup do vrchoviny, neobývatel'nej v eneolite. A napokon tu môže úlohu zohrávat vel'mi nedostatočný stav bádania regiónu a malý počet evidovaných archeologických komponentov, pri ktorom každý nový nález nami načrtnutý model výrazne pozmení. Ak sa vrátime k eneolitu, zdá sa, že badenské osídlenie okupuje územie pôvodne obsadené populáciou skupiny Lažňany, avšak rozšírilo sa aj do bočných dolín. Otázkou d’alšieho bádania zostáva tzv. badenizácia pôvodom staroeneolitického obyvatel'stva na hornom Potisí, tento proces považujeme za možný. $V$ tom prípade by osídlenie staršej etapy stredného eneolitu $\mathrm{v}$ regióne plynule prešlo do jeho mladšej fázy bez výmeny obyvatelstva. Na druhú stranu skutočnoste, že v povodí Sekčova neevidujeme výšinné polohy badenskej kultúry, ktoré sú typickým prejavom jej záverečného obdobia v susedných regiónoch (György 2014, 177 nn; Horváthová 2010, 28; Malček 2016; Malček/Blažová/Botoš, v tlači; Novotná/Soják 2013), snád' naznačuje ukončenie osídlenia sekčovského údolia už v klasickom stupni dotknutého kultúrneho okruhu. Mohylníky, ktoré sú evidované na severe krajiny sa viažu na iný kultúrny okruh a inú chronologickú sekvenciu. Územie v povodí Sekčova zasahujú pravdepodobne iba okrajovo. 


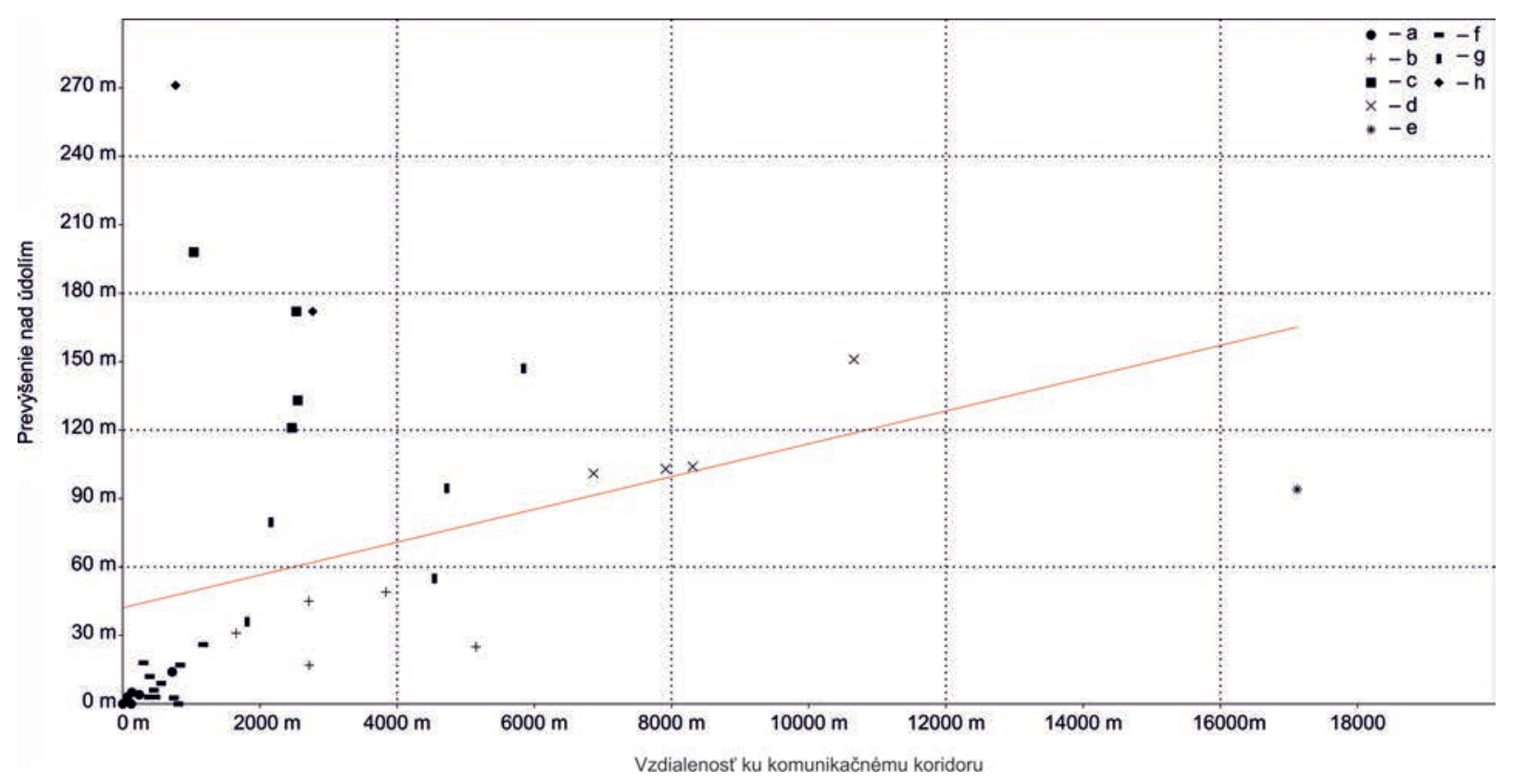

Obr. 9. Porovnanie modelov zonácie neolitického osídlenia v povodí Sekčova a Torysy vo vztłahu k nadmorskej výške a vzdialenosti od komunikačného koridoru. Legenda: a - zóna Se_NE1; b - zóna Se_NE2; c - Se_zóna NE3; d - zóna Se_NE4; e - zóna Se_NE5; f - zóna To_NE1; g - zóna To_NE2; h - zóna To-NE3.

\section{ZÁVER}

Záverom možno porovnat’ situáciu pozorovanú v povodí Sekčova s pomermi v susednom údolí Torysy, ktorým sme už venovali jednu štúdiu (Malček a i. 2018). Podotýkame, že porovnanie mierne słažuje pozmenená metodika získavania údajov. Navyše sme v období písania zmienenej štúdie nedisponovali podrobnou pôdnou mapou, preto komparácia na úrovni informačnej vrstvy „Environmentálne dáta" ani nie je možná. V tomto kontexte uvedieme, že v údolí Torysy neolit zastupovala najmä bukovohorská kultúra s 18 lokalitami, s ktorými sme dalej pracovali a roztriedili ich do troch sídelných zón. Aj táto skutočnost komparáciu deformuje, kedžze v údolí Sekčova, vzhladom na ich malý počet, triedime spolu náleziská bukovohorskej kultúry a kultúry s východnou lineárnou keramikou. Napriek uvedenému sa zdá, že lokality zón Se_NE1 a To_NE1 ${ }^{27}$ sú situované do toho istého krajinného pásma. Rozdiely neukazuje ani lineárna regresia, ani štatistické testovanie (,Vzdialenost' ku koridoru“ $-\mathrm{p}=0,1531$, „Prevýšenie nad údolím“ - $p=0,4627$, „Nadmorská výška" $-p=0,1378)$. Naopak sa však javí situácia pri zhluku To_NE2, ktorý reprezentoval osídlenie bočných údolí toryského povodia. Tento zhluk zastupuje lokality rozptýlené na širokom území a sledovanými parametrami (,,Vzdialenost' od koridoru“, „Prevýšenie nad hlavným údolím“ a „Nadmorská výška“) sa od klastrov Se_NE2, Se_NE3 a Se_NE4 štatisticky neodlišuje. $\mathrm{V}$ podstate to isté možno konštatovat aj o zhluku To_NE3, ktorý reprezentuje výšinné polohy, hoci v tomto prípade lineárna regresia ukazuje na väčšiu blízkost’ ku klastru Se_NE3 (obr. 9). Pokial' možno výsledky porovnania zhrnút, zdá sa, že dôvod tohto rozptylu spočíva $v$ texte už uvedenej ekonomickej stratégii, ktorá sa mohla vo vyššie situovaných údoliach orientovat' na pastierstvo, a to podmieňovalo zvýšenú mobilitu takto hospodáriacich skupín. Vyzerá to, že v povodí Sekčova sa tieto skupiny vzd’alovali d’alej od hlavného údolia. To, že osídlenie dna hlavného údolia s relatívne úrodnými pôdami v oboch prípadoch percentuálnym zastúpením dominuje, možno pravdepodobne interpretovat tak, že dominantnou stratégiou bolo v oboch regiónoch kombinované hospodárenie (kopaničiarstvo a pastierstvo). Extrémne situované výšinné polohy klastru To_NE3 opät naznačujú, že v bukovohorskej chronologickej sekvencii došlo $\mathrm{k}$ politickým alebo ideologickým zmenám.

$\mathrm{V}$ eneolite máme $\mathrm{z}$ údolia Torysy informácie o 32 eneolitických lokalitách. V zmienenej štúdii sme však pracovali len s 13 komponentmi badenskej kultúry, ktoré sme roztriedili opät do troch zón. Na rozdiel od neolitu nevykazuje porovnanie eneolitického osídlenia oboch susediacich oblastí vel'ké rozdiely, totiž, štatisticky významné rozdiely sa nezistili medzi náprotivkami (Se_EN1 - To_EN1, 


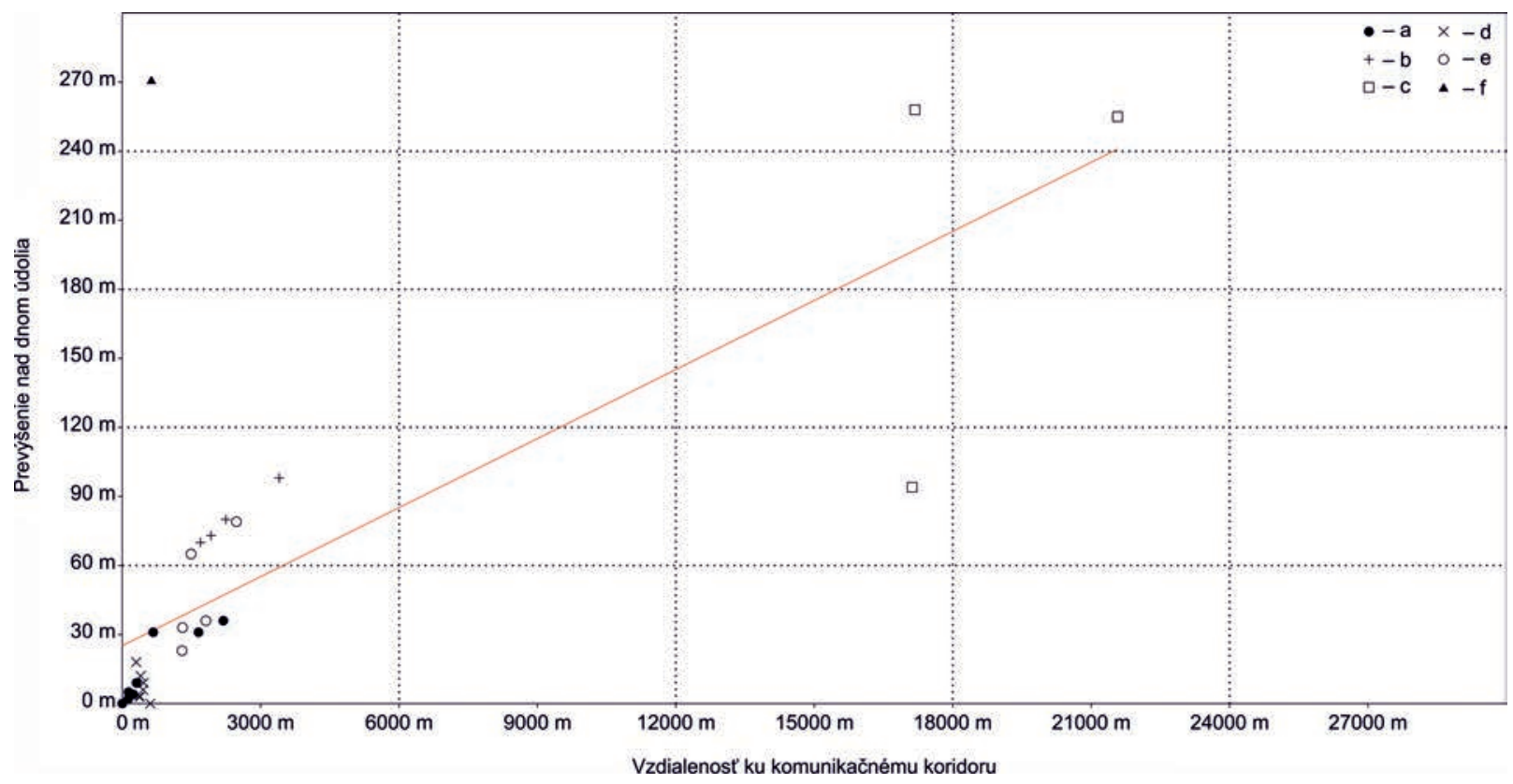

Obr. 10. Porovnanie modelov zonácie eneolitického osídlenia v povodí Sekčova a Torysy vo vztahu k nadmorskej výške a vzdialenosti od komunikačného koridoru. Legenda: a - zóna Se_EN1; b - zóna Se_EN2; c - Se_zóna EN3; d - zóna To_EN1; e-zóna To_EN2; f-zóna To_EN3.

Se_EN2 - To_EN2) a potvrdili sa v ostatných prípadoch. To ukazuje aj výsledok lineárnej regresie premenných „Vzdialenost’ od komunikačného koridoru“ a "Prevýšenie nad hlavným údolím", podla ktorého sa eneolitické osídlenie celej oblasti (avšak v údolí Torysy reprezentované len badenskou kultúrou) zoskupuje do zovretých zhlukov (obr. 10). Z dvoch pôvodných klastrov sa vydeluje samostatné zoskupenie, ktoré reprezentujú ich hraničné lokality. Extrémne je situovaná jednak jediná lokalita klastru To_EN3 (teda výšinná poloha, ktorá na Sekčove chýba), jednak lokality zóny Se_EN3, ktoré zväčša reprezentujú obdobie neskorého eneolitu.

Z uvedeného vyvodzujeme, že v strednom eneolite možno v oboch povodiach pozorovat analogickú sídliskovú stratégiu, odrážajúcu pravdepodobne aj rovnakú stratégiu adaptačnú, ktorá sa na druhú stranu odlišovala od vyššie preberaných postupov v neolite. Pokial' sa spolahneme na výsledky hore realizovanej analýzy, exploatácia krajiny sa v daných zónach zameriavala skôr na pol'né hospodárenie, a teda na exploatáciu ostrovov úrodnejších pôd, čo by vysvetlovalo aj zovretejší charakter osídlenia. Otázkou zostáva postavenie jedinej lokality evidovanej v zóne To_EN3 (Šarišský hradný vrch). Podobne ako pri neolite, jej parametre naznačujú iný, ako ekonomický význam takéhoto miesta. Napokon dodáme, že prezentované výsledky komparácie považujeme len za úvodný krok dalšieho bádania, v ktorom sa zameriame na korekciu už zozbieraných dát (to sa týka najmä údolia Torysy) a na zber dát aj z iných regiónov Slovenska.

\section{LITERATÚRA}

Bánesz/Vizdal 1993 - L. Bánesz/M. Vizdal: Ďalšie paleolitické nálezy z extravilánu Vel'kého Šariša. AVANS 1992, 1993, 22, 23.

Bárta 1983 - J. Bárta: Prieskum paleolitických komunikačných priechodov v Nízkych Beskydách. AVANS 1982, 1983, 32-35.

Bielich/Luštíková 2008 - M. Bielich/L. Luštíková: Praveké nálezy z Prešova-Kútov. AVANS 2006, 2008, 41, 42.

Blahuta 1959 - F. Blahuta: Bukovohorské sídlisko v Kapušanoch. Slovenská archeológia 7, 1959, 5-32.
Blahuta 1960 - F. Blahuta: Archeologický profil Šariša. Nové obzory 2, 1960, 95-119.

Blahuta 1963 - F. Blahuta: Novšie archeologické objavy na severovýchodnom Slovensku. Študijné zvesti Aú SAV 11, 1963, 169-178.

Budinský-Krička 1958 - V. Budinský-Krička: Archeológia, Krajské múzeum a pamiatky mesta Rožňava. Martin 1958.

Budinský-Krička 1965 - V. Budinský-Krička: Doba bronzová a halštatská. In: I. Sedlák a kol.: Dejiny Prešova I. Košice 1965, 39-46. 
Budinský-Krička 1967 - V. Budinský-Krička: Východoslovenské mohyly. Slovenská archeológia 15, 1967, 277-388.

Budinský-Krička 1970 - V. Budinský-Krička: Záchranný výskum roku 1964 v Koprivnici, okr. Bardejov. Východoslovenský pravek 1, 1970, 57-94.

Budinský-Krička 1976 - V. Budinský-Krička: Predkuštanovické žiarové pohrebisko vo Vojnatine. Slovenská archeológia 24, 1976, 119-149.

Budinský-Krička 1978a - V. Budinský-Krička: Archeologické prieskumy a nálezy na východnom Slovensku. AVANS 1977, 1978, 39-56.

Budinský-Krička 1979 - V. Budinský-Krička: Nové nálezy na východnom Slovensku. AVANS 1978, 1979, 46-65.

Budinský-Krička 1982a - V. Budinský-Krička: Nové nálezy na východnom Slovensku. AVANS 1981, 1982, 44-57.

Budinský-Krička 1984a-V. Budinský-Krička: Nové nálezy na východnom Slovensku. AVANS 1983, 1984, 51-61.

Budinský-Krička 1986 - V. Budinský-Krička: Nové nálezy na východnom Slovensku. AVANS 1985, 1986, 67-71.

Budinský-Krička 1991 - V. Budinský-Krička: K otázke skupiny východoslovenských mohýl. Východoslovenský pravek 3, 1991, 96-111.

Budinský-Krička/Macák 1992 - V. Budinský-Krička/P. Macák: Nové nálezy na východnom Slovensku. AVANS 1991, 1992, 24, 25.

Budinský-Krička/Mačala 1990 - V. Budinský-Krička/P. Mačala: Nové nálezy na východnom Slovensku. AVANS 1988, 1990, 42-46.

Budinský-Krička/Miroššayová 1992 - V. Budinský-Krička/ E. Miroššayová: Terňa-Lysá stráž - sídlisko z neskorej doby bronzovej a halštatskej. (Pokus o chronologické a kultúrne určenie.) Slovenská archeológia 40, 1992, 47-76.

Czekaj-Zastawny 2008 - A. Czekaj-Zastawny: Osadnictwo społeczności kultury ceramiki wstęgowej rytej w dorzeczu górnej Wisty. Kraków 2008.

Čaplovič/Slivka 1983 - D. Čaplovič/M. Slivka: Terénny prieskum v oblasti Šariša. AVANS 1982, 1983, 73-77.

Derfiňák/Karabinoš/Vizdal 2009a-P. Derfiňák/A. Karabinoš/ M. Vizdal: Mladopaleolitické stanice v Medzanoch. AVANS 2007, 2009, 59-61.

Derfiňák/Karabinoš/Vizdal 2009b-P. Derfiňák/A. Karabinoš/ M. Vizdal: Stredopaleolitická industria zo Šarišských Michalian. AVANS 2007, 2009, 61, 62.

Džatko 2002 - M. Džatko: Hodnotenie produkčného potenciálu polnohospodárskych pôd a pôdno-ekologických regiónov Slovenska. Bratislava 2002.

Džatko/Sobecká a kol. 2009 - M. Džatko/J. Sobecká a kol.: Príručka pre používanie máp pôdnoekologických jednotiek. Inovovaná príručka pre bonitáciu a hodnotenie pol'nohospodárskych pôd Slovenska. Bratislava 2009.

Hajnalová 1976 - E. Hajnalová: Prehlad botanických nálezov z výskumov Archeologického ústavu SAV v roku 1975. AVANS 1975, 1976, 95-101.

Horváthová 2010 - E. Horváthová: Osídlenie badenskej kultúry na slovenskom území severného Potisia. Archaeologica Slovaca Monographiae. Studia 13. Nitra 2010.

Hreha $2003 a$ - R. Hreha: Výsledky prieskumu na trase optického kábla na východnom Slovensku. AVANS 2002, 2003, 59-61.
Karabinoš/Volanská2015-A. Karabinoš/A. Vol’anská: Nález škrabadla z Medzian. AVANS 2010, 2015, 126.

Kaminská/Moravcová/Šefćáková 2014 - L'. Kaminská/M. Moravcová/A. Šefčáková: Staré Slovensko 2. Paleolit a mezolit. Archaeologica Slovaca Monographiae. Nitra 2014.

Klčo 1988 - M. Klčo: Paleolitický nález z Medzian. AVANS 1987, 1988, 75, 76.

Kolektív 1972 - J. Bako/J. Berta/O. Ferianc/Z. Feriancová-Masárová/O. Fusán/J. Futák/S. Hejný/A. Jurko/L. Korbel/M. Kurpelová/M. Lukniš/L'. Mičian/J. Michalko/ Š. Petrovič/Z. Schmidt/E. Šimo/F. Vilček/M. Zat'ko: Slovensko. Príroda. Bratislava 1972.

Kotorová-Jenčová 2015 - M. Kotorová-Jenčová: Výskum exteriéru kostola sv. Michala v Chmelovci. AVANS 2010, 2015, 127-129.

Kotorová-Jenčová 2017 - M. Kotorová-Jenčová: Výskum v Prešove-Šalgovíku. AVANS 2012, 2017, 97, 98.

Kušnír a i. 2015 - J. Kušnír/J. Babušáková/L. Jonov/A. Latta/ B. Lazorík/I.Lazorík/P.Ledvák/A.Nábožný/L. Novotná/ J. Ridilla: 70 rokov Krajského múzea v Prešove. Prešov 2015.

Lamiová-Schmiedlová 1970 - M. Lamiová-Schmiedlová: Súpis výskumov z rokov 1945-1968. Východoslovenský pravek 1, 1970, 139-163.

Lieskovský a i. 2015 - T. Lieskovský/J. Faixová-Chalachanová/R. Ďuriačová/E. Blažová/L. Karell: Archeologické predikčné modelovanie. Metódy a princípy. Bratislava 2015.

Luštíková 2018 - L. Luštíková: Lokality z doby rímskej na východnom Slovensku. Východoslovenský pravek 11, 2018, 75-109.

Malček 2016 - R. Malček: Badenské osídlenie Cerovej vrchoviny. Archaeologica Slovaca Monographiae. Fontes 21. Nitra 2016.

Malček/Blažová/Botoš, v tlači - R. Malček/E. Blažová/ A. Botoš: Model osídlenia Rimavskej kotliny vo vybratých obdobiach mladšieho praveku 1 . Neolit a eneolit. Študijné zvesti AÚ SAV, v tlači.

Malček a i. 2018 - R. Malček/E. Horváthová/L. Luštíková/ R. Hreha: Rekonštrukcia osídlenia v okolí hornej a strednej Torysy vo vybraných obdobiach praveku až včasného stredoveku. Študijné zvesti AÚ SAV 64, 2018, 21-52.

Malinková/Švaňa 2017 - I. Malinková/K. Švaňa: Archeologický výskum na hrade Šebeš. AVANS 2012, 2017, 114-116.

Neustupný 1995 - E. Neustupný: The significance of facts. Journal of European Archaeology 3, 1995, 189-212.

Neustupný 2007 - E. Neustupný: Metoda archeologie. Plzeň 2007.

Novotná/Soják 2013 - M. Novotná/M. Soják: Vel'ká Lomnica-Burchbrich. Urzeitliches Dorf unter den Hohen Tatras. Archaeologica Slovaca Monographiae. Studia 16. Nitra 2013.

Nowak/Vizdal 2002 - M. Nowak/M. Vizdal: Správa z výskumných sondážnych výskumov vo Finticiach. AVANS 2001, 2002, 144, 145.

Olexa/Tunia 1996 - L. Olexa/K. Tunia: Slovensko-pol'ský prieskum v Karpatoch. AVANS 1994, 1996, 132-136.

Slivka/Mačala 1985 - M. Slivka/P. Mačala: Terénny prieskum v jednom z mikroregiónov Šariša. AVANS $1984,1985,215-218$. 
Šiška 1966 -S. Šiška: K počiatkom kultúry s kanelovanou keramikou. Slovenská archeológia 14, 1966, 49-76.

Šiška 1976 - S. Šiška: Sídlisko z mladšej doby kamennej v Prešove-Šarišských Lúkach. Slovenská archeológia 24, 1976, 83-117.

Šiška 1993 - S. Šiška: Poznámky k neolitickým osadám v Kapušanoch a Fulianke, okr. Prešov. Východoslovenský pravek 4, 1993, 37-40.

Tomášová 1991 - B. Tomášová: Nálezy z okolia Prešova. AVANS 1989, 1991, 99.

Tomášová 1998 - B. Tomášová: Kamenná industria z okolia Prešova. AVANS 1996, 1998, 158.

Tomášová 2000 - B. Tomášová: Rímska spona z hradu Solivar. AVANS 1999, 2000, 136.

Tomášová/Karabinoš 2006 - B. Tomášová/A. Karabinoš: Nové nálezy z Prešova-Solivaru. AVANS 2004, 2006, 194, 195.

Tunia 2008 - K. Tunia: Słowacko polskie archeologiczne badania powierzchniowe w górnym dorzeczu Topli, Słowacja. In: J. Machnik (ed.): Archeologia i środowisko naturalne Beskidu Niskiego w Karpatach II. Kurimská brázda. Kraków 2008, 41-138.

Tunia/Mačala 1997 - K. Tunia/P. Mačala: Pol'sko-slovenský archeologický prieskum v Karpatoch. AVANS 1995, 1997, 176-178.

Valde-Nowak 2008 - P. Valde-Nowak: Paleolityczne zabytky ze stanoviska Marhaň, okr. Bardejov (Słowacja). In: J. Machnik (ed.): Archeologia i środowisko naturalne Beskidu Niskiego w Karpatach II. Kurimská brázda. Kraków 2008, 139-156.

Vizdal 1991 - M. Vizdal: Prieskumy v okolí Prešova. AVANS 1989, 1991, 105, 106.

Vizdal 1992 - M. Vizdal: Prieskum výšinných polôh v extraviláne Prešova. AVANS 1990, 1992, 102, 103.

Vizdal 2000 - M. Vizdal: Výsledky prieskumu vo Finticiach. AVANS 1999, 2000, 153.

Vizdal/Derfiňák 2004 - M. Vizdal/P. Derfiňák: Výsledky prieskumu v extraviláne Prešova. AVANS 2003, 2004, 200, 201.

\section{NEPUBLIKOVANÉ PRAMENE}

Béreš 2002 - J. Béreš: Bartošovce. Poloha Podstavenec. Nitra 2002. Výskumná správa 14832/02. Dokumentácia AÚ SAV Nitra.

Bielich 2006 - M. Bielich: Prešov. Poloha Kúty. Nitra 2006. Výskumná správa 16044/06. Dokumentácia AÚ SAV Nitra.

Blahuta 1956a - F. Blahuta: Kapušany. Poloha Sýpka a silážna jama JRD. Prešov 1956. Výskumná správa 477/56. Dokumentácia AÚ SAV Nitra.

Blahuta 1956b - F. Blahuta: Kapušany. Poloha Sýpka a silážna jama JRD. Prešov 1956. Výskumná správa 2136/56. Dokumentácia AÚ SAV Nitra.

Blahuta 1957a - F. Blahuta: Fulianka. Poloha Most (pravý breh Sekčova). Prešov 1957. Výskumná správa 530/57. Dokumentácia AÚ SAV Nitra.

Blahuta 1957b - F. Blahuta: Vyšná Šebastová, čast’ Sengetov. Poloha Košiare/Košariská/Košarisky. Prešov 1957. Výskumná správa 629/57. Dokumentácia AÚ SAV Nitra.

Budinský-Krička 1950 - V. Budinský-Krička: Fintice. Poloha Várhegy. Turčiansky Svätý Martin 1950. Výskumná správa 1174/50. Dokumentácia AÚ SAV Nitra.

Budinský-Krička 1954a - V. Budinský-Krička: Kapušany. Poloha Pravý strmý breh Sekčova (severovýchodne od mosta). Košice 1954. Výskumná správa 164/54. Dokumentácia AÚ SAV Nitra.

Budinský-Krička 1954b - V. Budinský-Krička: Prešov. Poloha Sútok Sekčova s Torysou. Košice 1954. Výskumná správa 299/54. Dokumentácia AÚ SAV Nitra.

Budinský-Krička 1956a-V. Budinský-Krička: Fulianka. Poloha Most (pravý breh Sekčova). Košice 1956. Výskumná správa 2504/56. Dokumentácia AÚ SAV Nitra.

Budinský-Krička 1956b - V. Budinský-Krička: Fulianka. Poloha Terasa Ternianky. Košice 1956. Výskumná správa bez uvedenia identifikačného čísla. Dokumentácia AÚ SAV Nitra.

Budinský-Krička 1956c - V. Budinský-Krička: Tulčík. Poloha Južný svah kopca Deriky/Drieky. Košice 1956. Výskumná správa. Dokumentácia AÚ SAV Košice.

Budinský-Krička 1957a - V. Budinský-Krička: Kapušany. Poloha Hradný vrch (severozápadne od zrúcanín). Košice 1957. Výskumná správa 35/57. Dokumentácia AÚ SAV Nitra.
Budinský-Krička 1957b - V. Budinský-Krička: Kapušany Poloha Severovýchodne od mosta pri Sekčove. Košice 1957. Výskumná správa 35/57. Dokumentácia AÚ SAV Nitra.

Budinský-Krička 1957c - V. Budinský-Krička: Tročany. Poloha Vrch Prilesok. Košice 1957. Výskumná správa bez uvedenia identifikačného čísla. Dokumentácia AÚ SAV Košice.

Budinský-Krička 1959 - V. Budinský-Krička: Klušov. Poloha Hrebeň Kobyl'skej hory. Košice 1959. Výskumná správa 100/59. Dokumentácia AÚ SAV Nitra.

Budinský-Krička 1960a-V. Budinský-Krička: Chmelov. Poloha Almáš (Olmáš). Košice 1960. Výskumná správa 389/60. Dokumentácia AÚ SAV Nitra.

Budinský-Krička 1960b - V. Budinský-Krička: Terňa. Poloha Juhovýchodné úbočie kopca Košariská. Košice 1960. Výskumná správa 194/60. Dokumentácia AÚ SAV Nitra.

Budinský-Krička 1960c - V. Budinský-Krička: Terňa. Poloha Juhovýchodné úbočie kopca Košariská. Košice 1960. Výskumná správa 212/60. Dokumentácia AÚ SAV Nitra.

Budinský-Krička 1960d - V. Budinský-Krička: Terňa. Poloha Juhovýchodné úbočie kopca Košariská. Košice 1960. Výskumná správa 246/60. Dokumentácia AÚ SAV Nitra.

Budinský-Krička 1960e - V. Budinský-Krička: Prešov-Solivar. Pokusné vrty. Košice 1960. Výskumná správa 565/60. Dokumentácia AÚ SAV Nitra.

Budinský-Krička 1960f-V. Budinský-Krička: Prešov-Šalgovík. Poloha Šalgovské jarky. Košice 1960. Výskumná správa 1/60. Dokumentácia AÚ SAV Nitra.

Budinský-Krička 1961 - V. Budinský-Krička: Klušov. Poloha Hrebeň Kobyl’skej hory. Košice 1961. Výskumná správa 61/61. Dokumentácia AÚ SAV Nitra.

Budinský-Krička 1964a - V. Budinský-Krička: Fulianka. Poloha Most (pravý breh Sekčova). Košice 1964. Výskumná správa 613/64. Dokumentácia AÚ SAV Nitra.

Budinský-Krička 1964b - V. Budinský-Krička: Klušov. Poloha Hrebeň Kobyl'skej hory. Košice 1964. Výskumná správa 2134/64. Dokumentácia AÚ SAV Nitra.

Budinský-Krička 1969 - V. Budinský-Krička: Nemcovce. Poloha Dluhé. Košice 1969. Výskumná správa 4793/69. Dokumentácia AÚ SAV Nitra. 
Budinský-Krička 1972a - V. Budinský-Krička: Fulianka. Poloha Most (pravý breh Sekčova). Košice 1972. Výskumná správa 528/72. Dokumentácia AÚ SAV Nitra.

Budinský-Krička 1972b - V. Budinský-Krička: Vyšná Šebastová, čast’ Sengetov. Poloha Intravilán (dom 125). Košice 1972. Výskumná správa 69/72. Dokumentácia AÚ SAV Nitra.

Budinský-Krička 1972c - V. Budinský-Krička: Klušov. Košice 1972. Výskumná správa 6055/72. Dokumentácia AÚ SAV Nitra.

Budinský-Krička 1974 - V. Budinský-Krička: Prešov-Solivar. Poloha Valkovská ulica 4. Košice 1974. Výskumná správa 7131/74. Dokumentácia AÚ SAV Nitra.

Budinský-Krička 1977 - V. Budinský-Krička: Záhradné. Poloha Sútok Ternianky a Morušovanky (dvor ludovej školy). Košice 1977. Výskumná správa 8169/77. Dokumentácia AÚ SAV Nitra.

Budinský-Krička 1978b - V. Budinský-Krička: Záhradné. Poloha Bývalá farská záhrada (kultúrny dom). Košice 1978. Výskumná správa 8612/78. Dokumentácia AÚ SAV Nitra.

Budinský-Krička 1982b - V. Budinský-Krička: Kapušany. Poloha Pod lesom. Košice 1982. Výskumná správa 9959/82. Dokumentácia AÚ SAV Nitra.

Budinský-Krička 1984b - V. Budinský-Krička: Chmel'ov. Poloha Meseš (Močidlo). Košice 1984. Výskumná správa 10602/84. Dokumentácia AÚ SAV Nitra.

Budinský-Krička 1984c-V. Budinský-Krička: Kapušany. Poloha Maderasy. Košice 1984. Výskumná správa 10700/84. Dokumentácia AÚ SAV v Nitre.

Budinský-Krička 1984d - V. Budinský-Krička: Lada. Poloha Rozhranie honov Fisere a Záhrady. Košice 1984. Výskumná správa 10701/84. Dokumentácia AÚ SAV Nitra.

Budinský-Krička 1988 - V. Budinský-Krička: Správa z prieskumov J. Macáka v Kapušanoch, Fulianke a Finticiach. Košice 1988. Výskumná správa 2088/88. Dokumentácia AÚ SAV Nitra.

György 2014 - L. György: Észak-Magyarország a késő rézkorban. A Baden-kultúra leletei Borsod-Abaúj-Zemplén megyében. Doktori disszertáció. Eötvös Loránd Tudományegyetem Bölcsészettudományi Kar. Budapest 2014. Dostupné na: https://edit.elte.hu/xmlui/handle/10831/22316

Horñák/Krištofová/Rejdovianová 2013 - M. Horňák/V. Krištofová/Z. Rejdovianová: L’ubotice. Poloha Medzi L’uboticami a sídliskom Sekčov. Vrútky 2013. Výskumná správa 16/2013. Dokumentácia AÚ SAV Nitra.

Hreha 2003b - R. Hreha: Kapušany. Poloha Pod lesom. Košice 2003. Výskumná správa 15098/03. Dokumentácia AÚ SAV Nitra.

Rukopis prijatý 7. 11. 2020

Translated by Viera Tejbusová

Mgr. Róbert Malček, PhD.

Archeologický ústav SAV

Štúrova 2

SK - 96053 Zvolen

malcek@ife.sk

PhDr. Eva Horváthová, PhD.

Archeologický ústav SAV

Hrnčiarska 13

SK - 04001 Košice

ehorvath@saske.sk
Krička 1941 - V. Krička: Nemcovce, okr. Giraltovce. Mohyly $z$ doby eneolitickej. List zo dňa 3. 11. 1941. Štátny archeologický ústav v Turčianskom Sv. Martine. Dokumentácia AÚ SAV Nitra.

Lieskovský 2011 - T. Lieskovský: Využitie geografických informačných systémov v predikčnom modelovaní varcheológii. Dizertačná práca. Slovenská technická univerzita v Bratislave. Stavebná fakulta. Bratislava 2011.

Macák 1970 - J. Macák: Trnkov. Poloha Povyše kríža na západnej strane hradskej smerom k obci Okružná. Košice 1970. Výskumná správa 490/70. Dokumentácia AÚ SAV Nitra.

Müllerová 2015 - M. Müllerová: Fintice. Poloha Fisky-Tormáš. Michalovce 2015. Výskumná správa 1158/118. Dokumentácia AÚ SAV Nitra.

Repčák 1951 - J. Repčák: Tulčík. Poloha Severný svah kopca Deriky. Košice 1951. Výskumná správa 350/51. Dokumentácia AÚ SAV Košice.

Repčák 1953a - J. Repčák: Chmelov. Poloha Almáš (Olmáš). Košice 1953. Výskumná správa 85/53. Dokumentácia AÚ SAV Nitra.

Repčák 1953b - J. Repčák: Podhorany. Poloha Bol’ava. Košice 1953. Výskumná správa bez uvedenia čísla. Dokumentácia AÚ SAV Nitra.

Repčák 1953c - J. Repčák: Tulčík. Poloha Južne od obce na pravom brehu Sekčova. Košice 1953. Výskumná správa 340/53. Dokumentácia AÚ SAV Košice.

Šimčík $2015 a$ - P. Šimčík: Fintice. Kaštiel' (sýpka). Košice 2015. Výskumná správa 24/2015. Dokumentácia AÚ SAV Nitra.

Šimčík 2015b - P. Šimčík: Podhorany. Poloha Chotárka. Košice 2015. Výskumná správa 15/2015. Dokumentácia AÚ SAV Nitra.

Šimčík/Švaňa 2014 - P. Šimčík/K. Švaňa: Záhradné. Poloha Maliniak. Košice 2014. Výskumná správa 2/2014. Dokumentácia AÚ SAV Nitra.

Šimčík/Švaňa 2016 - P. Šimčík/K. Švaňa: Fintice, čast' FiskyTormáš. Poloha Martinec. Košice 2016. Výskumná správa 8/2016. Dokumentácia AÚ SAV Nitra.

Šimčík/Švaňa/Hupčík 2014 - P. Šimčík/K. Švaňa/M. Hupčík: Fintice, čast’ Fisky-Tormáš. Poloha Martinec. Košice 2014. Výskumná správa 3/2013-2014. Dokumentácia AÚ SAV Nitra.

Švaňa 2017 - K. Švaňa: Prešov-Šalgovík. Poloha Za kostolom. Košice 2017. Výskumná správa 13/2017. Dokumentácia AÚ SAV Nitra.

Mgr. Lucia Luštíková, $\mathrm{PhD}$.

Archeologický ústav SAV

Hrnčiarska 13

SK - 04001 Košice

lustikova@saske.sk 


\title{
A Model of Settlement of Northeastern Slovakia in the Sekčov Drainage Basin Based on Data Obtained from GIS Environment
}

\author{
Paleolithic, Neolithic, Eneolithic
}

\author{
Róbert Malček - Eva Horváthová - Lucia Luštíková
}

\author{
SUMMARY
}

The study is focused on the update of data on localization of archaeological sites near the Sekčov river and its contributaries in northeastern Slovakia. The monitored river basin with its length of $44.3 \mathrm{~km}$ drains an area of 35,714 ha. 69 archaeological sites belonging to 26 cadastral areas have been recorded in this territory. 18 of the cadastral areas are administratively included in the district of Prešov (62 sites), 6 of them belong to the district of Bardejov (7 sites).

The research included sites from the Paleolithic (without cultural identification), Neolithic (Eastern Linear Pottery culture, Bükk culture), Eneolithic (Lažňany group, Baden culture, Nyírszég-Zatín culture, Eastern Tumulus group of the Corded Ware culture), Bronze Age (Gava culture), Hallstatt, La Tène and Roman periods. Their localization is indicated on the maps. After the agreement on publishing the achieved results in the submitted publication in two stages due to the extent and complexity of the obtained information, the authors of the study are now presenting the first part dealing with more precise specification of the landscape's natural characteristics influencing development of settlement in the Paleolithic, Neolithic and Eneolithic.

Archaeological data are transferred to GIS software and combined with the secondary information layer of spatial and environmental data extracted from other vector and raster layers. The Digital elevation model (DMR) of Slovakia with raster definition of $10 \times 10$ m must be set as the basic layer. As for spatial data, altitude, orientation, slope, elevation above the terrain and roughness of the surface were monitored. A layer of potential water streams was created in GIS program and the distance to them was detected by the least cost path method. The authors of the study worked identically when tracing the main communication corridor which should be leading through the most walkable terrain at the bottom of the valley. The calculated line with regard to the width of the valley was extended to a $500 \mathrm{~m}$ wide zone to cover several possible variants of communication lines. The secondary layer of Environmental data was assessed on the basis of the map of the bonited soil-ecological units (hereinafter referred to as BSEU). These units can be grouped in 14 higher quality classes, i. e. in so-called typological-productivity categories (further referred to as TPC) characterizing the quality and usability of the given type of soil and make comparison of soil patterns in settlement areas easier.
The results obtained by means of the above described procedure were statistically tested. In the first step, components of individual periods were grouped by linear regression of the altitude and indirect distance to the communication corridor parameters. The extent of difference of individual parameters between such defined settlement zones was further tested by dispersion analysis. Parameters of both secondary information layers were tested, while emphasis is put on the layer of Environmental data. The analysis was carried out in PAST software. Settlement zones of individual periods are not confronted only with each other but also with the landscape context.

\section{Paleolithic}

The small number of exactly localized Paleolithic sites without cultural classification (sites 30, 50 and 51) does not allow their more detailed classification. Two of them are located approx. $2.6 \mathrm{~km}$ from each other in the southern part of the Sekčov valley, i. e. in the Košická kotlina basin, the third one is situated approx. $23 \mathrm{~km}$ north of them. It is located on a terrace-like jut above the confluence of the Hrabovec and Brôdok streams in the Ondavská vrchovina hills. With regard to the supposed economic strategy of Paleolithic groups of hunters and collectors, in this chapter the authors did not evaluate the settlement in relation to the pedological composition of the region. Thus, they only briefly mention results of the comparative analysis in the information layer of spatial data. According to them, the Paleolithic sites in the Sekčov river basin are located at the valley's bottom or on the lowest river terraces. The settled areas were located near water and were more or less southwest or west oriented. With regard to the fact that the elevation above the surrounding terrain does not reach high values, they were probably not hunting stations from which herds of game could be watched. Without further investigation, the topic of Paleolithic settlement near the Sekčov is unsolvable.

\section{Neolithic}

We have recorded 22 sites from the period of Neolithic. Linear regression at monitoring the parameters of altitude and distance to the communication corridor 
points to the dispersion of the Neolithic settlement into four or five landscape zones. The most compact cluster of settlements is recorded in zone NE1; zones NE3 and NE4 are considerably compact. On the other hand, zone NE2 is more dispersed. Excentrically in zone NE5, only one settlement is located (site 1, Bartošovce-Záhumnie). It is visible on the map that zone NE1 represents settlement of the Sekčov river valley, zone NE2 represents several side valleys mostly on the contributaries of the Ladianka (Kapušiansky and Porubský potok streams) and one site is situated on the right bank of the Sekčov, near the Fintický potok stream. Sites of zone NE3 including two upland sites are situated above it. Zone NE4 contains remote sites deep in stream valleys or on their periphery (Dlhý potok and Ternianka streams).

The five settlement zones of the Neolithic settlement in the Sekčov river basin are represented probably by three (or two) various types of purposefully chosen exploitation of landscape. From the economic point of view, location of the sites in zone NE1 can be considered the most convenient. The zone is also situated in the communication corridor. The sites are situated on terraces or slopes elevated several meters over the flood plain, which is also expressed in the surrounding terrain' characteristics. They have soils suitable to some - very limited - extent for dispersed upland farming settlements (mollic fluvisols) as well as areas suitable for breeding. If we assume that the communication route was leading through the valley, inhabitants of this zone could have controlled trade but in a case of external aggression, their settlements were located in the most exposed territory. Sites of zones NE2 and NE4 are located in landscape which could be used for pastures. Shepherding (?) groups occupied the whole areas but not extremely sloping ones (about $6^{\circ}$ ). They were relatively close to water (which did not necessarily have to be in the immediate vicinity of the activity's area). Settlements of all previously mentioned zones were more or less south oriented. This basically applies to the sites of zone NE3 as well; with other parameters, they differ from other zones. They are either situated on a steep slope or a hilltop considerably higher than its surroundings. In this case, we can consider a different function of such sites and their interpretation remains open. As far as upland sites are concerned, their practical use (as refuges or small fortresses) is possible, however, one of the trends in the current expert literature is to assign a symbolical function to them. Finds of human and animal bones in the areas of settlements 8 (Fintice-Košariská I) and 9 (Fintice-Košariská II) do not contradict this idea, unless they are traces of a forefield of a previously undefined upland settlement in the vicinity. The cadastral areas of Kapušany together with Fintice, i. e. approximately the middle stream of the Sekčov, seem to be the core of the Neolithic settlement at the current state of research. In this space, sites of zone NE1 are concentrated and the settled side valleys end there; upland sites are situated at the edge of this zone. The settlement practically does not reach the mountainous northern part of the river basin. Also with regard to this currently unsettled area, settlement of this region in the Neolithic seems to be very sparse ( 1 settlement per $\left.9 \mathrm{~km}^{2}\right)$, or even sparser in individual stages (Eastern Linear Pottery culture $28 \mathrm{~km}^{2}$; Bükk culture $24 \mathrm{~km}^{2}$ ). From this point of view, a more exact image is provided by the analysis of the nearest neighbour carried out in GIS. From calculations of this algorithm, the observed distance between Neolithic components (21 sites) is $1.946 \mathrm{~km}$ and the assumed distance is $1.862 \mathrm{~km}$; it is $2.483 / 3.224 \mathrm{~km}$ between the Eastern Linear Pottery culture sites and 2.555/3.016 km between the Bükk culture sites. No statistically relevant difference has been detected between these cultures.

The same applies to the dispersion of settlements of the above mentioned typological-chronological sequences in the landscape. Sites of both cultures are located in all zones together, however, sites of the Bükk culture are predominant in zones NE2, NE3 and NE4. The fact that finds of the Bükk culture (similarly to e. g. Gemer) have been preliminarily recorded at the upland sites appears to be important. In spite of this, it can be stated that according to our current knowledge, Neolithic settlement in the Sekčov river basin remained unchaged through two following stages, with one exception - upland sites. Thus, it cannot be excluded that one Neolithic group was settled on the middle and lower Sekčov stream for a longer time with economy which might have included dispersed upland farming settlements (in the main valley), however, it was considerably dependent on shepherding (occupation of side valleys). Settling protected upland sites in the second stage of settlement could suggest a change in the 'political' or 'ideological' context.

\section{Eneolithic}

From the total number of 28 sites, only 18 can be identified in the terrain. Linear regression at monitoring of the parameters of altitude and distance to the communication corridor shows dispersion of the settlement in three landscape zones. The most compact cluster is expressed in zone EN1; zone EN2 is identically compact, zone EN3 is excentrically located. We can see on the map that zone EN1 represents the settlement of the Sekčov's own valley, zone EN2 represents side valleys of the Šalgovický and Solný potok streams, i. e. left-side contributaries on the lower stream of the Sekčov. Both zones are situated in the Košická kotlina basin. Zone EN3 represents remote sites situated either on the upper (northern) Sekčov stream or, again, in the side valley of the Hrabovec and its contributaries located in the Ondavská vrchovina hills. Statistical analysis of the secondary information layers showed that settlement zones EN1 and EN2 probably represent one type of landscape exploitation. Comparison with the landscape context reveals intentional selection of settled areas. In this context, from the aspect of economy, we can, similarly to the Neolithic, consider location of settlements in zone EN1, which is also situated on the communication corridor, most convenient. The sites are situated on slightly sloping hills elevated above the bottom of the valley and they abound with soils suitable - to a rather limited extent - for ploughing (mollic fluvisols) or dispersed upland farms as well as with areas which could have been used for breeding. Control over a trade 
route is another advantage of this zone. Settlement of zone EN2 also searches for islands of more fertile soils, but - compared to zone EN1 - is disadvantaged in this aspect, since there are not many of such islands in the hills. Nevertheless, in this stage of research, we cannot observe - unlike the Neolithic - distinct traces of alternative exploitation of the landscape for pasturage. Remoteness from the trade route is a disadvantage of the archaeological sites situated in this zone. Upland sites which could be a sign of a structured model of settlement are not known in the region. In the current state of research, the territory of Solivar and the eastern edge of Prešov on the border with Šalgovík, i. e. approx. the Sekčov's middle stream, seem to be the core of the Eneolithic settlement. Individual settlements also occur in the main valley as far as the middle Sekčov stream. Settlement in the Early and Middle Eneolithic practically does not enter the mountainous northern part of the river valley. In the studied group, sites with the Baden culture prevail (6 sites) and it is this culture exclusively when settlement is distributed in several zones. Sites of the Lažňany group (2) and the Nyírség-Zatín culture (1) are located in zone EN1, i. e. in the Sekčov's valley. According to our current knowledge, settlement from the Late Stone Age in the Sekčov river valley further developed in the Middle Stone Age, when it is represented by the Baden culture, to which the authors relate further observations. Although a high proportion of pasturage is assumed in this archaeological culture's economy, the analysis of environmental data in the Sekčov valley suggests that agriculture was more important. Comparison of dispersion of Neolithic and Eneolithic sites in the region is essential from this point of view. It shows that the same territory was only occupied by groups NE1 and EN1. Other Neolithic and Eneolithic clusters occupy different landscape zones. The difference in the approach to the land is well observable at clusters of NE2 and EN2 representing settlement of the side valleys relatively near the main valley. In this case, the Eneolithic sites are located in a little higher altitude, however, they show a considerable proportion of arable soil of a higher quality in the hinterland - unlike the Neolithic components. After all, the accent on agriculture in the Eneolithic might be revealed by the change in the core of the settlement. Its shift from the middle stream (Neolithic) southwards (Eneolithic) can be interpreted as a shift from the pasturages in the mountainous areas to the island of more fertile soils on the lower Sekčov stream.

The differences in the approach to the landscape observed between the Neolithic and Eneolithic in the Sekčov valley could be hinding several interpretation lines. One of the explanations of the change could lie in the progress of agrotechnology which allowed exploitation of soils which were unusable in the Neolithic. That might be associated with the retreat of pasturage. A change of climate allowing the Neolithic population to move to the hills uninhabitable in the Eneolithic might be another explanation. Finally, the very insufficient state of research in the region and the small number of recorded archaeological sites could also play a certain role here.
Any new find from these sites will change the featured model significantly.

Going back to the Eneolithic, it seems that the Baden settlement occupies the area originally settled by the Lažňany group's population. Neverthelles, it expanded in the side valleys as well. The so-called Badenization of the originally Early Eneolithic population in the upper Tisza region remains the topic for further investigation; the authors consider such process possible. In such case, settlement of the older stage of the Middle Eneolithic in the region would continually transform into the younger stage withouth exchange of population. On the other hand, the fact that no upland sites from the Baden culture typical of its final stage in the neighbouring regions are known in the Sekčov river valley might suggest termination of the settlement in the Sekčov valley as early as the classical stage of the discussed cultural sphere. Tumulus grounds recorded in the north of the country are associated with a different cultural sphere and a different chronological sequence. They very probably reflect only marginal touch of the Eastern Tumulus culture's population of the Corded Ware culture.

In conclusion, the authors of the study confront the presented results of research with previously published information on the Neolithic and Eneolithic settlement near the upper and middle Torysa stream (Malček $a$ i. 2018). They point out that the comparison was made more difficult by the methodology of obtaining data which they had altered. In the Torysa valley, the Neolithic was represented mainly by the Bükk culture with 18 sites classified in three settlement zones. This fact deformed the comparison as well, since - with regard to their small number - sites of the Bükk culture were classified together with the Easern Linear Pottery culture's sites in the Sekčov valley. The fact that the Neolithic settlement of the bottom of the main valley with relatively fertile soils has predominant percentages in both cultures can possibly suggest that combined farming (dispersed upland farms and pasturage) was the dominant strategy in both regions. The extremely located upland sites of the Torysa_NE3 group again suggest that political or ideological changes occurred in the Bükk chronological sequence.

32 sites from the Eneolithic have been recorded in the Torysa valley. Only 13 sites of the Baden culture located in the three zones have been analyzed. Analogous settlement strategy can be observed in both valleys in the middle Eneolithic. If we can rely on the results of the analysis carried out above, exploitation of landscape in the studied zones focused on field work, i. e. exploitation of islands of more fertile soils, which would also explain the more compact character of settlement. Position of the only site recored in zone To_EN3 (Šarišský hradný vrch/Šariš castle hill) remains a question. Similarly to the Neolithic, the authors point out again that they consider the presented results of comparison only the initial step to further investigation in which they will focus on correction of the previously collected data (this applies to the Torysa river valley in particular) and on collection of data from other regions of Slovakia. 
Fig. 1. Map of Slovakia with indicated studied territory in the Sekčov river basin.

Fig. 2. Map of the studied territory in the Sekčov river basin. Cadastral areas of the villages with recorded archaeological sites are indicated with colours and Roman numerals. I - Bartošovce; II - Demjata; III Fintice; IV - Fulianka; V - Gregorovce; VI - Chmel'ov; VII - Chmelovec; VIII - Janovce; IX - Kapušany; X Klušov; XI - Kobyly; XII - Kochanovce; XIII - Lada; XIV - L'ubotice; XV - Nemcovce; XVI - Ol'šavce; XVII - Podohorany; XVIII - Prešov-Šalgovík; XIX Prešov-Solivar; XX - Prešov; XXI - Ruská Nová Ves; XXII - Terňa; XXIII - Tročany; XXIV - Tulčík; XXV Vyšná Šebastová; XXVI - Záhradné. Red points archaeological sites, olive green area - Sekčov river basin (Map by ŠÚGDŠ/Dionýz Štúr State Institute of Geology).

Fig. 3. Map of the original soil cover of the studied territory. $\mathrm{O} 2$ - highly productive arable soils,;O3 and O3_L - very productive arable soils; O4 and O4_L productive arable soils; $\mathrm{O} 5$ and O5_L - average productive arable soils; $\mathrm{O} 6$ and O6_L - less productive arable soils; O7 and O7_L - little productive arabale soils; OT1 - average productive fields and productive grasslands; OT2 and OT2_L - less productive fields and productive grasslands; OT3 and OT3_L - little productive fields and productive grasslands; $\mathrm{T} 1$ and T1_L - productive permanent grasslands; T2 and T2_L - less productive permanent grasslands; T3 little productive permanent grasslands; $\mathrm{N}$ and N_L areas unsuitable for agro-ecosystems. Symbol $\mathrm{L}$ in the codes means soils in forests from the original map (after Džatko 2002, tab. 5; map by ŠÚGDŠ and VÚPOP/ National Agriculture and Food Centre).

Fig. 4. Settlement of the Sekčov river basin from the Paleolithic to the Roman period - southern part. Arabic numerals on the map correspond with the ordinal numbers of the components in Tab. 2. Roman numbers of the cadastral areas are identical with the numbers in Figure 1. Legend: a - Paleolithic; b-Neolithic; c-Eneolithic; d - Bronze Age; e - Early Iron Age; f - Late Iron Age; $\mathrm{g}$ - Roman period. Numerical indication of the sites is identical with their indication in Tab. 2 (Map by ŠÚGDŠ).

Fig. 5. Settlement of the Sekčov river basin from the Paleolithic to the Roman period, the northern part. Arabic numerals on the map correspond with the ordinal numbers of the components in Tab. 2. Roman numerals of the cadastral areas are identical with the numbers in Figure 1. Legend: $a$ - Paleolithic; b - Neolithic; c-Eneolithic; d - Bronze Age; e-Roman period. Numerical indication of the sites is identical with their indication in Tab. 2 (Map by ŠÚGDŠ).

Fig. 6. Zonation model of the Neolithic settlement in the Sekčov river basin. 1 - comparison of settlement with regard to altitude and distance from the communication corridor; 2 - results of zonation depicted on a relief map. Legend: a - undefined classification; b - Eastern Linear Pottery culture; c - Eastern Linear Pottery culture and Bükk culture; d - Bükk culture; $\mathrm{g}-$ upland settlement. Colours of symbols: red - zone
NE1; blue - zone NE2; green - zone NE3; black - zone NE4; white - zone NE5. Numerical indication of the sites is identical with their indication in Tab. 2.

Fig. 7. Zonation model of the Eneolithic settlement in the Sekčov river basin. 1 - comparison of the settlement with regard to altitude and distance from the communication corridor; 2 - zonation results depicted on a relief map. Legend: a - unidentified classification; b - Lažňany group; c - Lažňany group and Baden culture; d - Baden culture; e Nyírség-Zatín culture; f - Eastern Tumulus group of the Corded Ware culture). Colours of symbols: red - zone EN1; blue - zone EN2; green - zone EN3. Numerical indication of the sites is identical with their indication in Tab. 2.

Fig. 8. Comparison of zonation models of the Neolithic and Eneolithic settlement in the Sekčov river basin with regard to altitude and distance from the communication corridor. Legend: $\mathrm{a}$ - zone NE1; $\mathrm{b}$ - zone NE2; c-zone NE3; d-zone NE4; e-zone NE5; f-zone EN1; g - zone EN2; h - zone EN3.

Fig. 9. Comparison of zonation models of the Neolithic settlement in the Sekčov and Torysa river basin with regard to altitude and distance from the communication corridor. Legend: $a$ - zone Se_NE1; $b$ - zone Se_NE2; c - Se_NE3; d - Se_NE4; e - zone Se-NE5; $\mathrm{f}$ - zone To_NE1; g - zone To_NE2; $\mathrm{h}$ - zone To_NE3.

Fig. 10. Comparison of zonation model of the Eneolithic settlement in the Sekčov and Torysa river basins with regard to altitude and distance from the communication corridor. Legend: $a$ - zone Se_EN1; b - zone Se_EN2; c - zone Se_EN3; d - zone To_EN1; e - zone To_EN2; f - zone To_EN3.

Tab. 1. List of the Sekčov's contributaries and monitoring of their routes in relation to geomorphological units and archaeological sites

Tab. 2. List of archaeological sites in the Sekčov's watershed. Abbreviations: PA - Paleolithic; PK - prehistory; NE - Neolithic; EN - Eneolithic; BZ - Bronze Age; HA - Hallstatt period; LT - LaTène period; RI - Roman period; ba - Baden culture; bu - Bükk culture; ga Gava culture; la - Lažňany group; lv - Eastern Linear Pottery culture; nz - Nyírség-Zatín culture; pi - Piliny culture; vm - Eastern Tumulus culture with Corded Ware; ml - early; ne - late; JV/SE - southeast; JZ/SW southwest; SV/NE - northeast; SZ/NW - northwest; JRD - agricultural cooperative.

Tab. 3. Taxonomic classification of geomorphological units of northeastern Slovakia in the Sekčov's watershed.

Tab. 4. Correction of archaeological sites in the territorialtechnical units.

Tab. 5. Paleolithic settlement, summary statistics of variables from the secondary information layer of 'Spatial data'.

Tab. 6. Neolithic settlement, summary statistics of variables from the secondary information layer of 'Spatial data'.

Tab. 7. Neolithic settlement, summary statistics of variables from the secondary information layer of 
'Environmental data - percentages of typologicalproductivity categories (TPC) in the settlement area'.

Tab. 8. Neolithic settlement. Five bonities of soil-ecological units (BSEU) with the strongest positive score according to the results of the principal component analyses (PCA) in zone NE1.

Tab. 9. Neolithic settlement. Five bonities of soil-ecological units with the strongest positive score according to the results of the principal component analyses in zone NE2.

Tab. 10. Neolithic settlement. Five bonities of soil-ecological units with the strongest positive score according to the results of the principal component analyses in zone NE3.

Tab. 11. Neolithic settlement. Five bonities of soil-ecological units with the strongest positive scores according to the results of the principal component analyses in zone NE4.
Tab. 12. Eneolithic settlement, summary statistics of variables from the secondary information layer of 'Spatial data'.

Tab. 13. Eneolithic settlement, summary statistics of variables from the secondary information layer of 'Environmental data - percentages of TPC in the settlement area'.

Tab. 14. Eneolithic settlement. Five bonities of soilecological units with the strongest positive scores according to the results of the principal components analyses in zone EN1.

Tab. 15. Eneolithic settlement. Five bonities of soilecological units with the strongest positive scores according to the results of the principal components analyses in zone EN2.

Tab. 16. Eneolithic settlement. Five bonities of soilecological units with the strongest positive scores according to the results of the principal components analyses in zone EN3. 
